\title{
Renewable Energy Opportunities at Fort Campbell, Tennessee/Kentucky
}

\author{
JR Hand JA Horner RJ Nesse, Project Manager \\ AR Kora AC Orrell \\ BJ Russo MR Weimar
}

March 2011

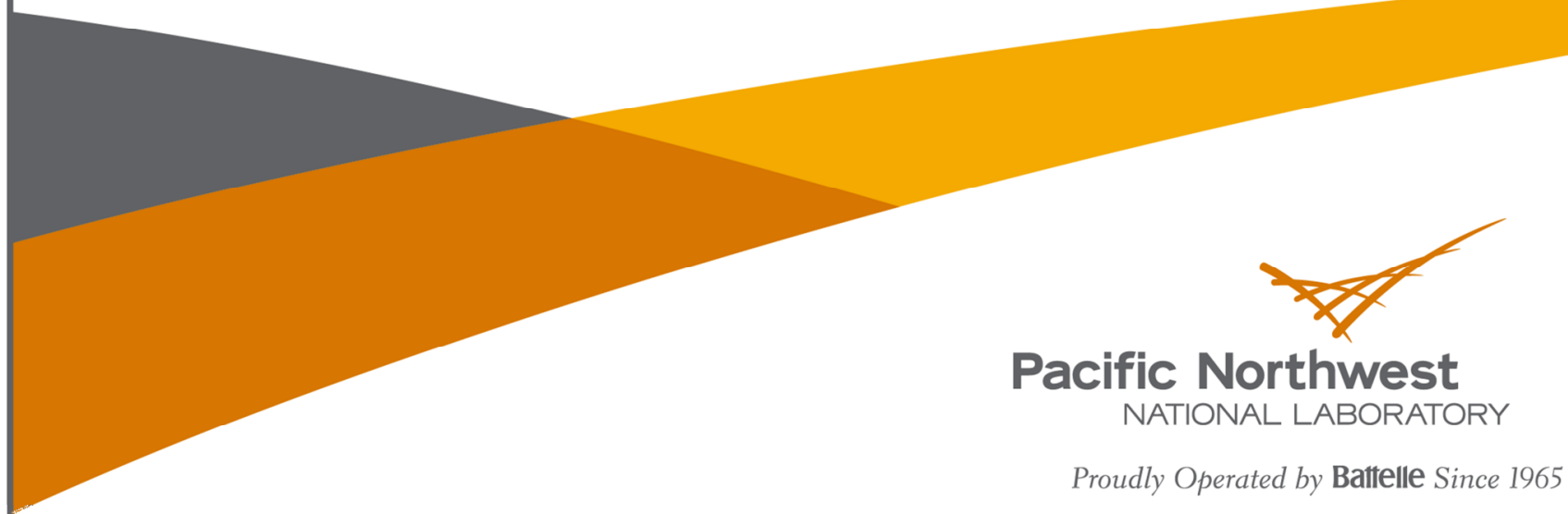




\title{
DISCLAIMER
}

United States Government. Neither the United States Government nor any agency thereof, nor Battelle Memorial Institute, nor any of their employees, makes any warranty, express or implied, or assumes any legal liability or responsibility for the accuracy, completeness, or usefulness of any information, apparatus, product, or process disclosed, or represents that its use would not infringe privately owned rights. Reference herein to any specific commercial product, process, or service by trade name, trademark, manufacturer, or otherwise does not necessarily constitute or imply its endorsement, recommendation, or favoring by the United States Government or any agency thereof, or Battelle Memorial Institute. The views and opinions of authors expressed herein do not necessarily state or reflect those of the United States Government or any agency thereof.

\author{
PACIFIC NORTHWEST NATIONAL LABORATORY \\ operated by \\ BATTELLE \\ for the \\ UNITED STATES DEPARTMENT OF ENERGY \\ under Contract DE-AC05-76RL01830 \\ Printed in the United States of America \\ Available to DOE and DOE contractors from the \\ Office of Scientific and Technical Information, \\ P.O. Box 62, Oak Ridge, TN 37831-0062; \\ ph: (865) 576-8401, fax: (865) 576-5728 \\ email: reports@adonis.osti.gov \\ Available to the public from the National Technical Information Service, \\ U.S. Department of Commerce, 5285 Port Royal Rd., Springfield, VA 22161 \\ ph: (800) 553-6847, fax: (703) 605-6900 \\ email: orders@ntis.fedworld.gov \\ online ordering: http://www.ntis.gov/ordering.htm
}

This document was printed on recycled paper.

$(8 / 00)$ 
PNNL-20223

\title{
Renewable Energy Opportunities at Fort Campbell, Tennessee/Kentucky
}

\author{
JR Hand JA Horner RJ Nesse, Project Manager \\ AR Kora AC Orrell \\ BJ Russo MR Weimar
}

March 2011

Prepared for

the U.S. Army Installation Management Command Headquarters

under Contract DE-AC05-76RL01830

Related Services

Pacific Northwest National Laboratory

Richland, Washington 99352 
Renewable Energy Opportunities at Fort Campbell, Tennessee/Kentucky Pacific Northwest National Laboratory, March 2011 


\section{Executive Summary}

Increasing use of renewable energy is mandated by several Executive Orders and various pieces of legislation. The goal of this report is to help Army personnel make sense of renewable energy at Fort Campbell.

This document provides an overview of renewable resource potential at Fort Campbell, based primarily upon analysis of secondary data sources supplemented with limited on-site evaluations. This effort focuses on grid-connected generation of electricity from renewable energy sources and also on ground source heat pumps for heating and cooling buildings. The effort was funded by the U.S. Army Installation Management Command (IMCOM) as follow-on to the 2005 Department of Defense (DoD) Renewables Assessment. The site visit to Fort Campbell took place on June 10, 2010.

At this time, some renewable technologies show economic potential at Fort Campbell. Project feasibility is based on installation-specific resource availability and energy costs and projections based on accepted life-cycle cost methods. The most promising renewable resource opportunities are landfill gas, waste-to-energy, and a limited number of ground source heat pump applications. Biomass is also promising, but will require a large plant in excess of Fort Campbell's immediate needs. Lastly, shale gas may also be an option for Fort Campbell.

\section{Biomass}

Agriculture is prevalent in the areas surrounding Fort Campbell, and there appears to be sufficient wheat, corn, and barely residue to support a 79-MW gasification plant. A plant of this capacity is well in excess of Fort Campbell's immediate electrical needs, so surplus power would need to be sold back to the grid. A smaller plant could be considered, but the savings to investment ratio, which was calculated to be 1.2 for the $79-\mathrm{MW}$ plant, would likely be lower than 1.0 for a smaller plant. Given this result, a biomass plant would be given a relatively low priority compared to other potential renewable energy sources.

\section{Ground Source Heat Pumps}

GSHP retrofits were analyzed using data from a 2009 PNNL data-gathering trip. Because of the site's imbalanced heating and cooling loads, the relatively inexpensive cost of natural gas, and high demand charges, ground source heat pumps were found to be suitable for only a narrow subset of buildings including older offices/warehouses, barracks, and the fitness center. Open loop and horizontal systems may be cost-effective for appropriated financing, but are not likely suitable for third party financing because of their lackluster economic performance. In general, these buildings need to be air-conditioned to have cost-effective GSHP projects. Simple paybacks for all scenarios range from 10 to 13 years.

\section{Waste to Energy and Landfill Gas}

Multiple off-site municipal solid waste (MSW) scenarios showed favorable economics in the initial screening. Two MSW projects and one landfill gas (LFG) scenario appear to support economic electricity generation at this time. Two different technologies were examined for the MSW analysis: gasification and combustion. For Fort Campbell, scenarios using gasification were more economical and had a savings-to-investment ratio (SIR) of 1.9 versus 1.6 for 
combustion. However, the scale of these projects, at 20 to $27 \mathrm{MW}$ for combustion and gasification, respectively, is considerable and requires the combined waste stream of Fort Campbell, the family housing, and the Bi-County Landfill. Previous attempts to establish longterm waste to energy power plants in the area have not been successful. These prior attempts may pose a hurdle to future waste to energy projects as political and community buy-in may be challenging to secure.

Landfill gas initially appeared to be a possible option to generate electricity for Fort Campbell. The landfill gas project analyzed had an SIR of 2.6 for a 3.6-MW project. However, landfill gas is no longer available as this resource is being privately developed at the Bi-County Landfill.

\section{Other Renewable Resources}

Other renewable technologies did not prove to be cost-effective with current conditions and assumptions. Large biomass generation projects using mill residue and wastewater treatment plant sludge are impractical at this time due to insufficient feedstock availability. Projects involving the use of biomass fuels such as animal waste and dedicated energy crops are also not feasible due to their inability to support economic electricity generation. Solar projects are not likely to be cost-effective in the near future either, requiring an energy cost of about $30 \phi / \mathrm{kWh}$ to achieve a $10 \%$ internal rate of return. Wind projects are not likely to be economic principally because of the low wind energy potential. Also, there is no known high-temperature geothermal resource on Fort Campbell.

Lastly, Fort Campbell personnel are aware of the shale gas potential in areas surrounding the site, and as a result, the site requested that PNNL perform a cursory review of existing literature to determine if there may be a shale gas resource. These resources indicate that Fort Campbell is located near the southern edge of the Illinois Basin. Recent drilling activity in the Illinois Basin has mainly been focused on shale gas produced from the New Albany Shale. The New Albany Shale is a Devonian age, rich shale that underlies much of the Illinois Basin. In general, the New Albany Shale is relatively shallow, and Fort Campbell is located to the south of the New Albany shale gas play, which is the region within the Illinois basin that is recognized for having an economically available quantity of gas. Additional investigations should focus on using existing published resources that could help identify the conditions of the New Albany Shale at Fort Campbell.

Renewable resources with at least some potential for being economic are summarized in Table 1 . 
Table 1: Summary of Promising Renewable Energy Projects at Fort Campbell

\begin{tabular}{|c|c|c|c|c|c|c|c|c|}
\hline & $\begin{array}{l}\text { Renewable } \\
\text { Resource and } \\
\text { Technology }\end{array}$ & $\begin{array}{c}\text { Resource } \\
\text { Estimate }\end{array}$ & $\begin{array}{l}\text { Earliest } \\
\text { Output }\end{array}$ & Figures of Merit & $\begin{array}{l}\text { Financing } \\
\text { Mechanisms } \\
\text { Evaluated }\end{array}$ & Location--Requirements & Key Assumptions & $\begin{array}{l}\text { Next Steps } \\
\text { Comments }\end{array}$ \\
\hline \multirow{2}{*}{ 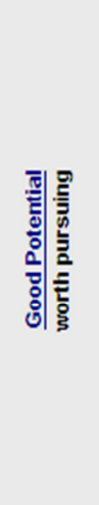 } & $\begin{array}{l}\text { Ground } \\
\text { Source Heat } \\
\text { Pump } \\
\text { (Thermal } \\
\text { Energy) }\end{array}$ & TBD & 2011 & $\begin{array}{l}\text { ECIP scenario: } \\
\text { SIR 1.0-1.5 } \\
\text { SPB 10.4 } 13.4\end{array}$ & $\begin{array}{l}\text { ECIP } \\
\text { IPP } \\
\text { UESC } \\
\text { ESPC }\end{array}$ & $\begin{array}{c}\text { Adequate heat sources } \\
\text { and sinks proximate to } \\
\text { GSHPS }\end{array}$ & $\begin{array}{l}\text { There are buildings } \\
\text { that require heating } \\
\text { and potentially cooling. } \\
\text { Suitable land area and } \\
\text { soil characteristics for } \\
\text { closed loop GSHPs. }\end{array}$ & $\begin{array}{l}\text { Suite surveys to } \\
\text { determine whether } \\
\text { suitable heat sinks } \\
\text { and sources exist, } \\
\text { and to provide the } \\
\text { detailed soil } \\
\text { characterization to } \\
\text { base system design. }\end{array}$ \\
\hline & $\begin{array}{l}\text { Waste to } \\
\text { Energy }\end{array}$ & 20-27 MW & 2013 & $\begin{array}{c}\text { SIR: } 1.6-1.9 ; \\
\text { SPB: } 7.5-9.1 \text { years }\end{array}$ & IPP & $\begin{array}{l}\text { A } 5 \text {-acre site near major } \\
\text { roads, a utility } \\
\text { substation, water, } \\
\text { sewage, and an } \\
\text { appropriate industrial } \\
\text { infrastructure }\end{array}$ & $\begin{array}{l}\text { Adequate MSW for the } \\
\text { plant sized selected. } \\
50 \% \text { of tipping fees } \\
\text { available with MSW to } \\
\text { plant. }\end{array}$ & $\begin{array}{l}\text { Confirm waste } \\
\text { availability and } \\
\text { tipping fees. } \\
\text { Economics are highly } \\
\text { dependent upon } \\
\text { tipping fee available } \\
\text { from waste providers. }\end{array}$ \\
\hline 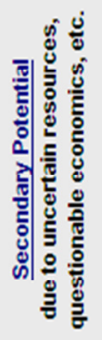 & $\begin{array}{l}\text { Biomass } \\
\text { Generation } \\
\text { Plant }\end{array}$ & $\begin{array}{c}79 \text { WW of } \\
\text { available } \\
\text { crop waste }\end{array}$ & 2013 & $\begin{array}{c}10 \% \text { IPP scenario }= \\
7.7 \text { \&/kWh break even } \\
\text { rate } \\
\text { ECIP scenario: } \\
\text { SIR } 1.2 \\
\text { SPB: } 11.1\end{array}$ & IPP & $\begin{array}{l}\text { A } 5 \text {-acre site near major } \\
\text { rods, a utility substation, } \\
\text { water, sewage, and an } \\
\text { appropriate industrial } \\
\text { infrastructure, plus } \\
\text { feedstock storage space }\end{array}$ & $\begin{array}{l}\text { Off-site crops will be } \\
\text { available for } \$ 20 \text { per } \\
\text { ton, sufficient on-site } \\
\text { storage is available }\end{array}$ & $\begin{array}{l}\text { Do not pursue this } \\
\text { technology unless } \\
\text { electric rates } \\
\text { increase. }\end{array}$ \\
\hline
\end{tabular}

ECIP = Energy Conservation Investment Program; SIR = savings-to-investment ratio; SPB = simple payback; IPP = independent power producer; UESC $=$ utility energy services contract; $\mathrm{ESPC}=$ energy savings performance contract 


\section{Table of Contents}

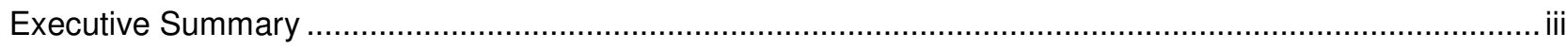

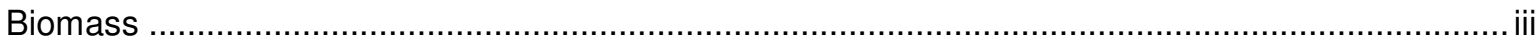

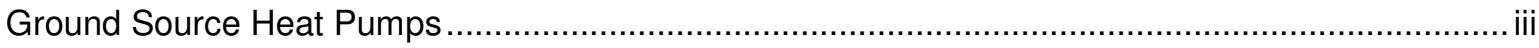

Waste to Energy and Landfill Gas ….....................................................................................

Other Renewable Resources .............................................................................................

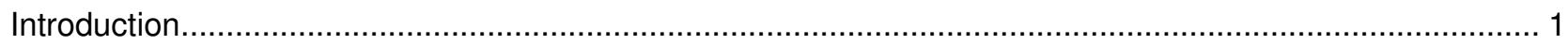

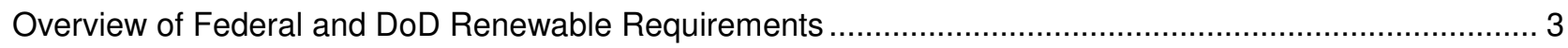

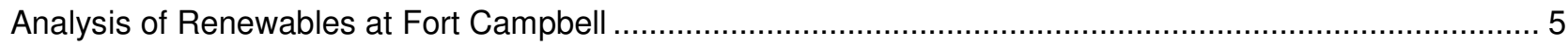

Approach for Identifying, Analyzing, and Implementing Renewable Energy Projects ...................... 5

Importance of Financing Mechanisms for Project Feasibility................................................... 6

The Political and Economic Environment for Renewables at Fort Campbell .................................. 6

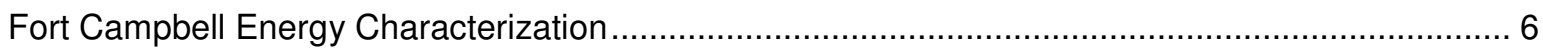

State Incentives for Renewable Project Development.............................................................. 7

Federal Incentives for Renewable Project Development .......................................................... 7

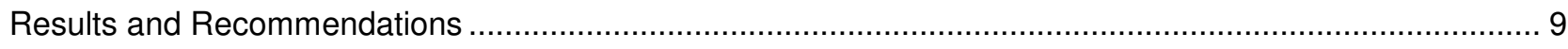

Ground Source Heat Pump Findings and Recommendations............................................... 10

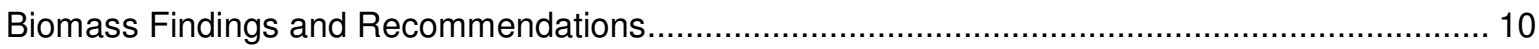

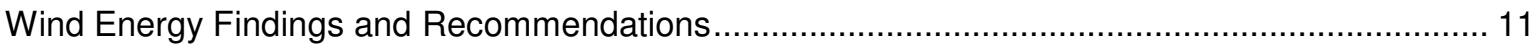

Solar Energy Findings and Recommendations .................................................................. 12

Waste-to-Energy Findings and Recommendations ........................................................... 12

Geothermal Power Findings and Recommendations ............................................................ 13

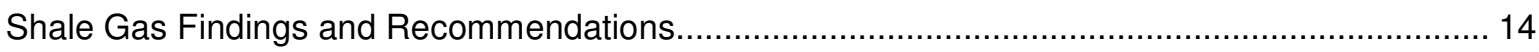

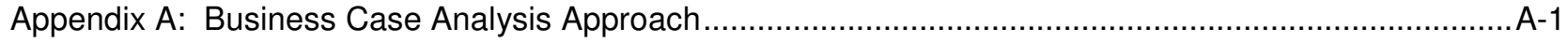

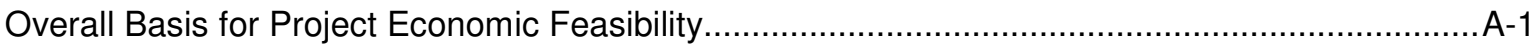

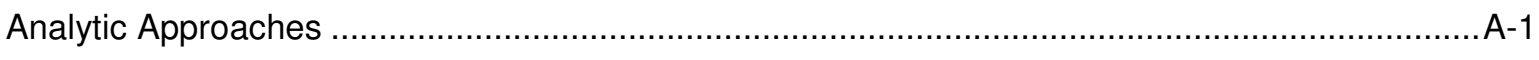

Independent Power Producer Assumptions........................................................................

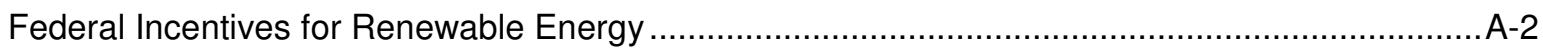

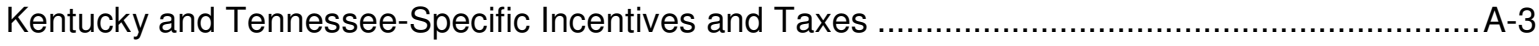

Other Independent Power Producer Assumptions .................................................................

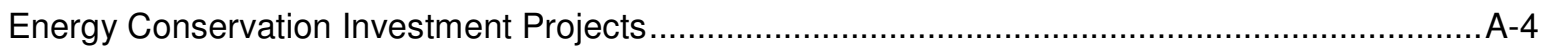

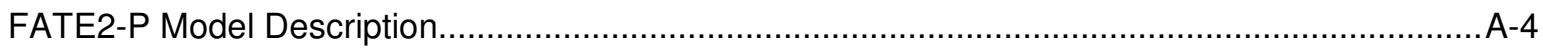

Private Ownership Rate of Return Methodology ....................................................................

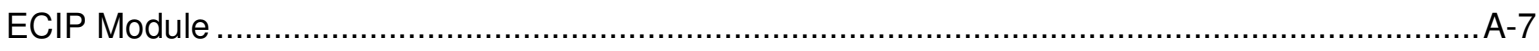

The Facility Energy Decision System (FEDS) Model ............................................................ 
Business Case Analysis Sources of Information ..................................................................

Appendix B: Analysis of Biomass and Waste-to-Energy Opportunities ...............................................

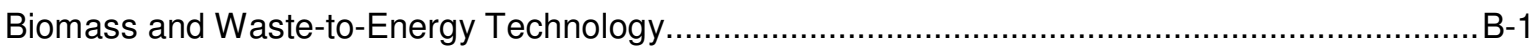

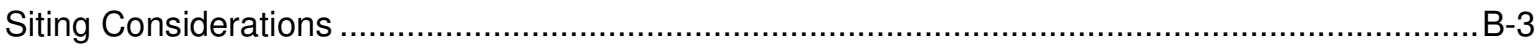

Biomass and Waste-to-Energy Analysis Approach ................................................................

Biomass and Waste Resource Characterization ................................................................

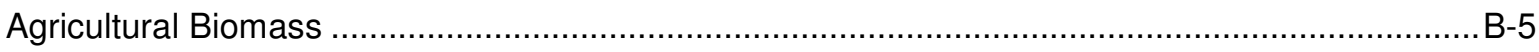

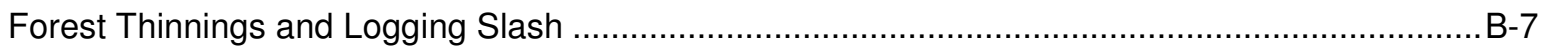

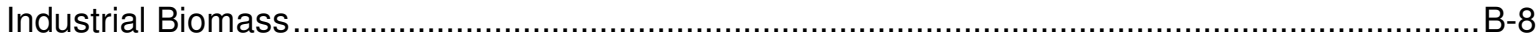

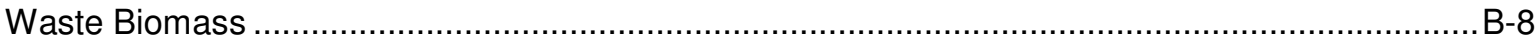

Biomass and Waste-to-Energy: Economic and Other Analysis Parameters ............................... B-11

Findings: Biomass and Waste-to-Energy Opportunities .....................................................

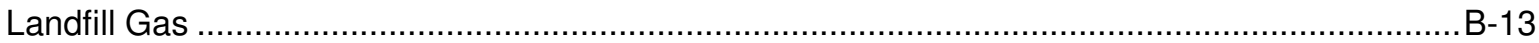

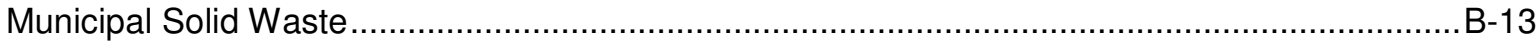

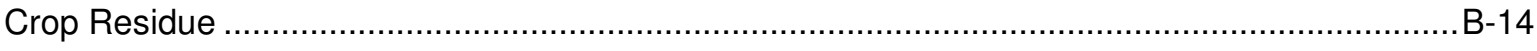

Biomass and Waste-to-Energy: Next Steps....................................................................... 15

Biomass and Waste-to-Energy Sources of Information .........................................................

Appendix C: Analysis of Geothermal Power Plant Opportunities ......................................................... -1

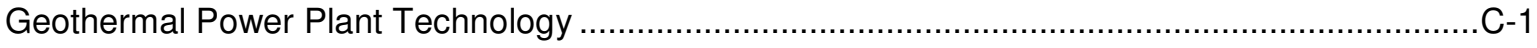

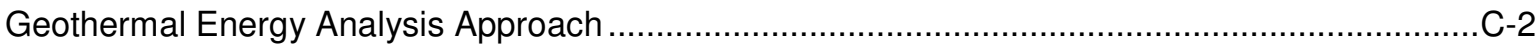

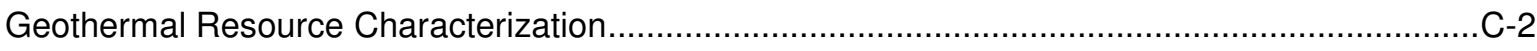

Geothermal Power Plants: Economic and Other Analysis Parameters .......................................-4

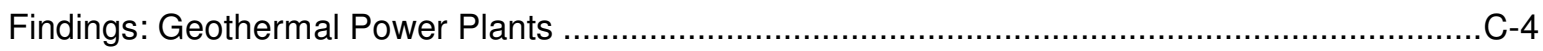

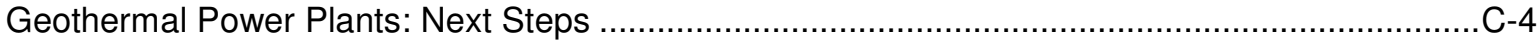

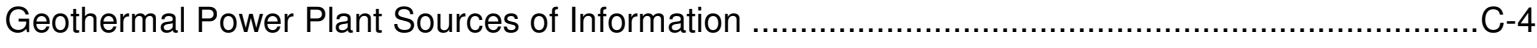

Appendix D: Analysis of Ground Source Heat Pump Opportunities ......................................................

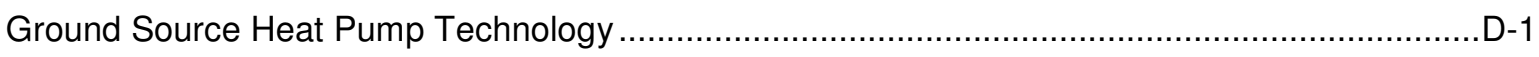

Ground Source Heat Pump Analysis Approach..........................................................................

Ground Source Heat Pump Resource Characterization .............................................................

Ground Source Heat Pumps: Economic and Other Analysis Parameters.................................

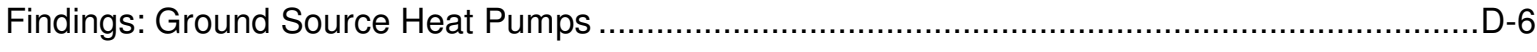

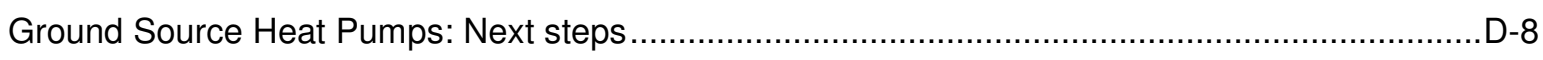

Ground Source Heat Pump Sources of Information ...................................................................

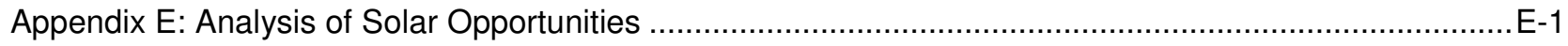

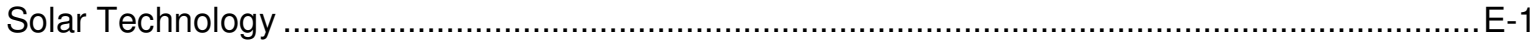

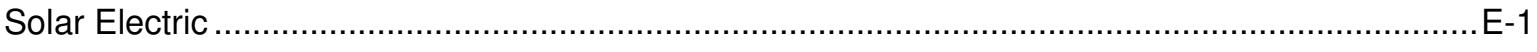

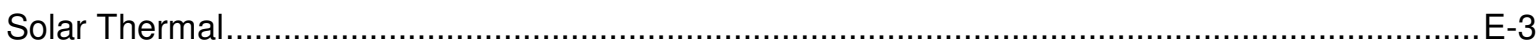




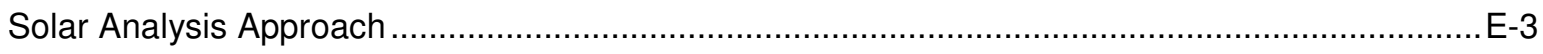

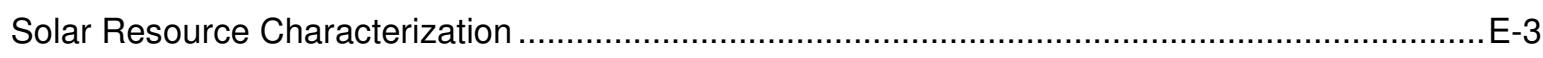

Siting Considerations for PV Technologies..........................................................................

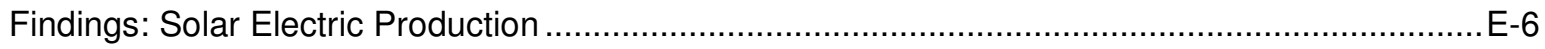

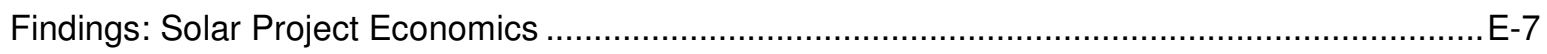

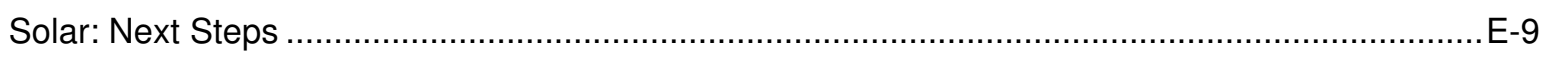

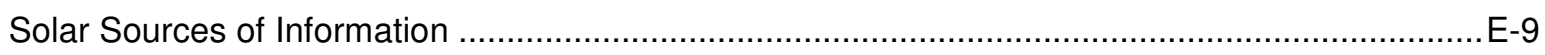

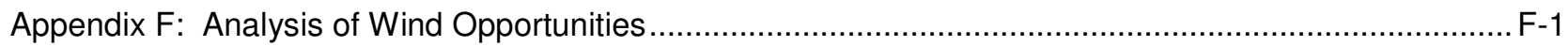

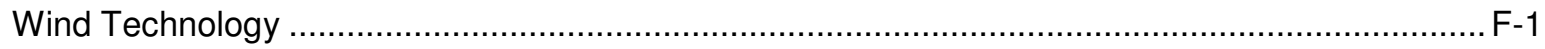

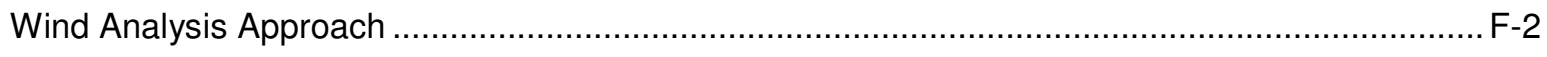

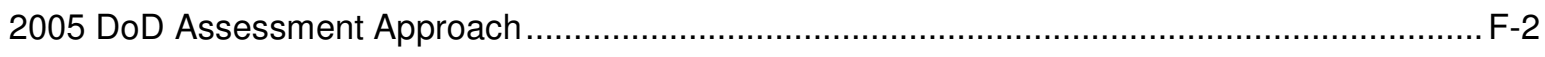

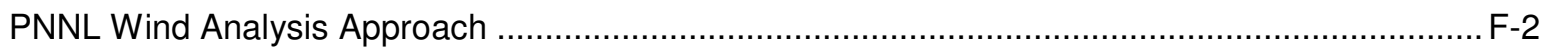

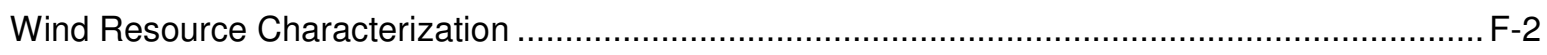

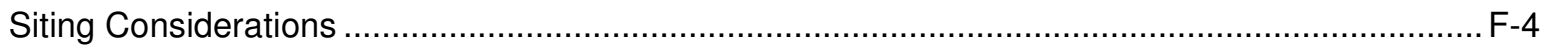

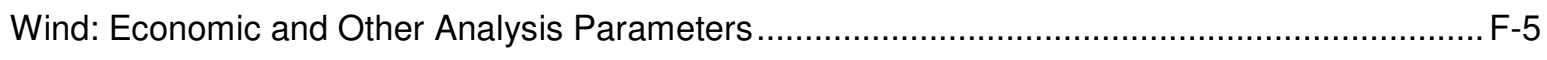

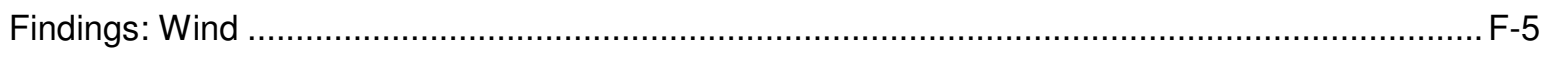

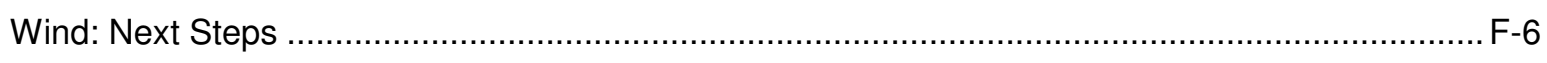

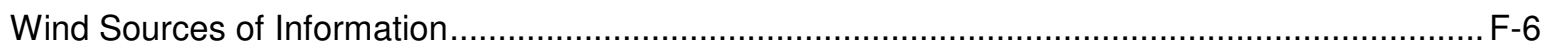

Appendix G: Analysis of Shale Gas Opportunities ....................................................................... G-1

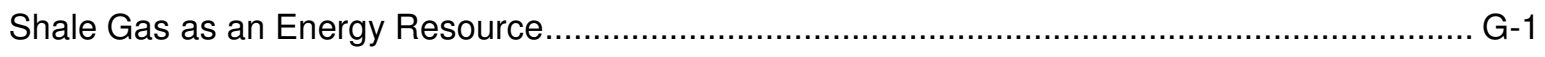

Shale Gas Opportunities at Fort Campbell ........................................................................ G-1 


\section{Figures}

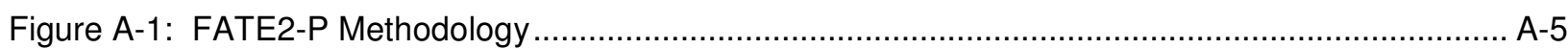

Figure C-1: Location of Boreholes with Published Geothermal Data near Fort Campbell .................... C-3

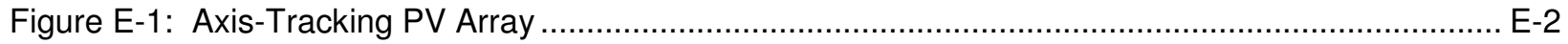

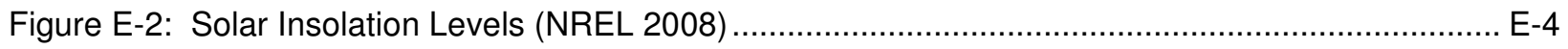

Figure E-3: Average Daily Insolation at Fort Campbell................................................................. E-5

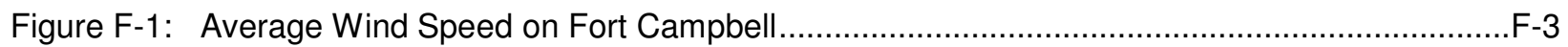

Figure G-1: Map of Illinois Basin (Smith Oil Group INC., 2006) …..................................................

Figure G-2: Location of Fort Campbell in Relation to the New Albany Shale Gas Play (EIA 2010)......... G-2 


\section{Tables}

Table 1: Summary of Promising Renewable Energy Projects at Fort Campbell ..................................... v

Table 2: Legislated Renewable Energy Targets for DoD ................................................................ 3

Table 3: Summary of Fort Campbell Renewable Energy Opportunities .................................................. 9

Table 4: Simple Payback Periods for Building Groups Analyzed in FEDS ${ }^{*}$........................................... 10

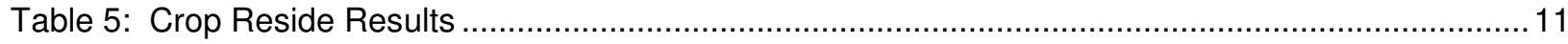

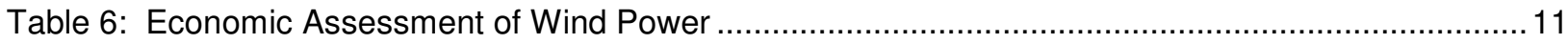

Table 7: Economic Results for Solar Technologies ........................................................................ 12

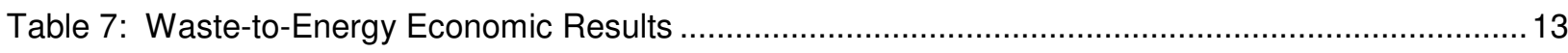

Table A-1: MACRS Depreciation Rates for Renewable Energy Projects .............................................. A-3

Table A-2: Discount Rate Assumptions in the ECIP Model .......................................................... A-4

Table B-1: Crops and Biomass Production near Fort Campbell...................................................... B-6

Table B-2: Waste near Fort Campbell .............................................................................................. B-9

Table B-3: Economic Assumptions, constant \$2010 ..................................................................... B-12

Table D-1: Building Groups Analyzed in FEDS for GSHPs ............................................................. D-3

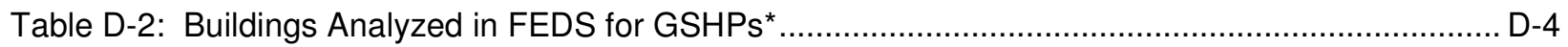

Table D-3: Simple Payback Period for Building Groups Analyzed in FEDS for GSHPs* .................... D-6

Table D-4: Simple Payback Period for Building Groups Analyzed in FEDS for GSHPs ${ }^{\star}$...................... D-7

Table E-1: Monthly Averaged Insolation Incident on a South-Facing Tilted Surface at Fort Campbell

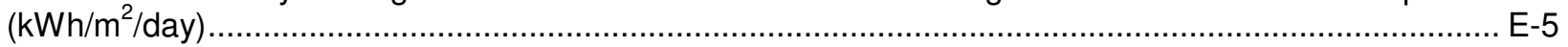

Table E-3: Solar Electric Production by System Type at Fort Campbell ................................................ E-6

Table E-3: Economic Results for Solar Technologies at Fort Campbell.............................................. E-7

Table F-1: Classes of Wind Power Density at 50 Meters ...............................................................

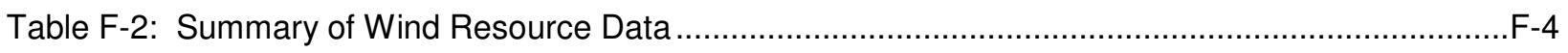

Table F-3: Performance, Cost, and Economic Characteristics...........................................................F-5

Table F-4: Economic Assessment of Wind Power..........................................................................F-6 


\section{Introduction}

Pacific Northwest National Laboratory (PNNL) has been directed by the U.S. Army Installation Management Command (IMCOM) to conduct detailed analyses of the potential for electricity generation at selected U.S. Army installations. The goal of the analyses is to identify economically feasible opportunities for generation of electricity from renewable resourcesgeneration that is significant enough to warrant connection to the grid and/or to contribute in a meaningful way to the aggressive renewable energy goals of the Army and the Department of Defense (DoD).

In 2005, PNNL led a study to identify utility-scale electricity generation opportunities at DoD installations. That study focused on solar, wind, and geothermal. A limited number of attractive large-scale commercial opportunities were identified, and their implementation is now being pursued. The study also identified a number of potential smaller opportunities that needed to be investigated further before project implementation decisions could be made.

This analysis of opportunities at Fort Campbell is one of the suite of analyses being conducted at Army installations as follow-on to the 2005 study. The goal is to revisit potential renewable opportunities, updating the analysis for changes in economics, incentives, knowledge about the available renewable resource, and other factors. It is focused on any size project greater than 1 MW. In addition, IMCOM has directed PNNL to evaluate the potential for biomass, waste-toenergy, and retrofitting heating and cooling systems in existing buildings with ground source heat pumps (GSHPs). Retrofitting with GSHPs is obviously not an electricity generation opportunity, but it is an opportunity for significant energy savings and replacement of fossil fuels across DoD, and can contribute toward some renewable goals. As part of the analysis, IMCOM has directed PNNL to lay out the steps necessary to implement the project opportunities that are identified.

The overall findings of this analysis are summarized in the main body of the report. The business case approach that underlies the analysis of each renewable technology is documented in Appendix A. Appendix B describes the analysis conducted on biomass and waste-to-energy technologies. Appendix C describes the geothermal analysis; Appendix D, the GSHP analysis; Appendix E, the solar analysis; Appendix F, the wind energy analysis, and Appendix G, shale gas. 


\section{Overview of Federal and DoD Renewable Requirements}

The Army needs to satisfy multiple goals and constraints while securing its energy suppliesfocusing on procurement of the lowest-cost energy that meets high reliability standards and minimum vulnerability to interruption from natural or intentional causes. Overlaid on this challenge is the need to comply with a series of somewhat contradictory statutes and policies, as laid out in Table 2. These include:

- Energy Policy Act (EPAct) Section 203. This law mandates the minimum contribution of renewable electricity to an installation's total electricity consumption to the extent that it is economically feasible and technically practicable. The target fractions are $3 \%$ for FY 2007 through FY 2009, 5\% through FY 2012, and not less than 7.5\% beginning in FY 2013.

- Executive Order (EO) 13423. The Executive Order reiterates the EPAct goals; however, it uses a different basis than EPAct for measuring and crediting progress. For example, renewable thermal energy counts toward the renewable goal.

- National Defense Authorization Act (NDAA). The NDAA codifies DoD's voluntary goal of $25 \%$ by 2025 , but does not include any interim targets. Renewable thermal energy counts toward the renewable goal.

- Energy Independence and Security Act (EISA). EISA established two additional renewable goals for new buildings and retrofits. One requires $30 \%$ of domestic hot water to be supplied from solar energy, and the other requires all fossil fuels used in buildings to be displaced by 2030. This is not an energy generation goal like the others, but is important to note.

Table 2: Legislated Renewable Energy Targets for DoD

\begin{tabular}{|l|c|c|c|c|}
\hline & $\begin{array}{c}\text { EPAct Section } \\
\mathbf{2 0 3}\end{array}$ & $\begin{array}{c}\text { Executive Order } \\
\mathbf{1 3 4 2 3}\end{array}$ & $\begin{array}{c}\text { National Defense } \\
\text { Authorization } \\
\text { Act }\end{array}$ & $\begin{array}{c}\text { Energy } \\
\text { Independence } \\
\text { and Security Act }\end{array}$ \\
\hline Target / Goal & $\begin{array}{c}\text { Increasing targets } \\
\text { reaching 7.5\% of } \\
\text { electric energy } \\
\text { from renewables }\end{array}$ & $\begin{array}{c}7.5 \% \text { of electric } \\
\text { energy from } \\
\text { renewables; 50\% } \\
\text { from new (post- } \\
\text { 1998) sources }\end{array}$ & $\begin{array}{c}\text { Equivalent of } \\
25 \% \text { of electric } \\
\text { energy from } \\
\text { renewables }\end{array}$ & $\begin{array}{c}\text { 30\% of hot water } \\
\text { demand from } \\
\text { solar }\end{array}$ \\
\hline Target Dates & 2013 & 2013 & 2025 & $\begin{array}{c}\text { All new } \\
\text { construction / } \\
\text { major renovations }\end{array}$ \\
\hline Mandatory? & Yes & Yes & No & Yes \\
\hline $\begin{array}{l}\text { Considers thermal } \\
\text { energy "renewable"? }\end{array}$ & No & Yes & Yes & N/A \\
\hline \hline
\end{tabular}

This assessment is primarily for renewable energy provision and retrofit applications in existing buildings. Accordingly, potential in new building construction is mentioned only in passing. The Department of Energy (DOE) is responsible for developing guidance for EPAct and EO 13423. DOE's guidelines for EO compliance, unlike EPAct, allow credit for renewable energy that reduces electricity use from thermal sources; however, it adds a requirement that at least 
$50 \%$ of renewable energy must come from "new" resources, which are those put into service after January 1, 1999.

Congress did not provide a definition of "renewable" in the NDAA language, and DOE is not responsible for establishing DoD or Army policies to achieve the goals in the NDAA. The current Army energy strategy and associated draft renewable policy takes an expansive view of renewables that encompasses thermal energy from renewable sources. As a result, the Army needs to proceed in a way that makes sense for the Army in a good faith effort to satisfy Congressional, Administration, and Pentagon mandates and directives. The expectation is that the Army will meet the stricter definitions of EPAct on its way to meeting the much higher renewable goals of the NDAA. 


\section{Analysis of Renewables at Fort Campbell}

PNNL's renewable energy analysis includes a preliminary assessment based on readily available information sources, a site visit to present the preliminary findings and gather additional information, and a concluding assessment, which is documented in this report.

The site visit to Fort Campbell took place on June 10, 2010 with Bryan Russo and Ron Nesse attending for PNNL. Fort Campbell personnel at the briefing included the site's energy manager Dewayne Smith.

\section{Approach for Identifying, Analyzing, and Implementing Renewable Energy Projects}

Renewable energy resources are unlike conventional resources because the "fuel" is essentially free. However, harnessing this free resource requires substantial investment in resource exploration, characterization, and collection; project development; and ongoing maintenance and operation.

Economical development of renewable energy depends upon these critical elements:

- Access to a renewable resource,

- Development costs, and

- Financing that is economically attractive and allowed by Federal and DoD regulations.

Naturally, a renewable resource has to be available and accessible to be developed. The best resources are those with the greatest potential for displacing conventional fuels or power supplies. Development cost, however, can be prohibitive, and a project based upon an excellent resource located many miles away from utility lines may be inferior to a project based upon a lesser resource nearby. For example, an excellent wind resource far from an adequate transmission line may be less attractive than an inferior resource adjacent to a transmission line. Similarly, "free" waste resources that could be used in a central plant may not be economic if the transportation, handling, and storage costs are greater than the continued use of conventional heating fuels.

Development costs are relatively comparable for similar size projects, irrespective of resource quality. For this reason, the quality of the resource is important because for the same investment, a site will produce more energy from a higher quality resource than a lower quality one.

However, development costs also include access to transmission capacity for shipping power to users, or alternatively, access to a retail customer. This is a critical difference, because power shipped over transmission lines has to compete with the prevailing wholesale price for power from conventional resources. Typically, renewables are not competitive in these markets, unless a buyer specifically demands renewable power. However, if the power can be used on-site to displace power purchased from the local utility, it competes against that customer's retail rate. Because these rates include costs for transmission, distribution, and overhead costs, they are higher than wholesale power prices and make competing renewable projects more economically attractive.

It is important that economic analyses of renewable energy opportunities use realistic data on avoided energy costs, project costs, and available incentives. A common analytic mistake is the use of average cost per kWh, the so-called "blended" rate, for all renewable energy analyses. 
Using the blended rate will lead to inaccurate results when a renewable resource is intermittent (as is the case with wind and solar resources) because intermittent resources cannot be guaranteed to reduce peak demand. Even non-intermittent resources may not result in reduced peak demand because of periodic maintenance shutdowns and unscheduled outages. The economic analyses in this report use only the energy component of the electricity bill (i.e., the marginal rate) to evaluate intermittent resources, which is admittedly conservative. The blended rate is used for economic analysis of base-load renewable energy systems.

Additionally, the installation's utility may impose a standby or other fee for a major on-site generation project that needs to be reflected in the project's cost calculation. The analyses conducted here make no assumptions regarding standby charges because those are typically assessed on a project-by-project basis.

The economic analyses in this report used two approaches: Energy Conservation Investment Program (ECIP) funding and third-party financing. Under the latter arrangement, power is sold through a contract that is commonly called a power purchase agreement (PPA). This analysis assumed that an internal rate of return (IRR) of $10 \%$ is the minimum required to attract a developer. The ECIP analyses assumed projects were not cost-effective if the savings-toinvestment ratio (SIR) was less than 1.0.

\section{Importance of Financing Mechanisms for Project Feasibility}

Financing is a critical part of development costs because the high first costs of renewable energy systems are sensitive to financial factors such as incentive payments, tax breaks, and interest rates. Incentive payments and tax breaks reduce first costs, lowering both the overall project cost and interest costs. Because financing is so critical, project economics (payback rates, life-cycle costs, etc.) constitute the best initial screen for project potential. This screen needs to reflect various financing alternatives, which helps energy managers decide on the best project development approach.

This study focuses on large projects that have a high degree of potential. Projects smaller than 1 MW are not analyzed except for special cases. The large projects analyzed typically exceed any realistic expectation for appropriated funding, and as a result, the assessments consider commercial (third-party) development of projects. Besides funding limitations, there are other reasons that these large projects should be implemented by third-party investors. Under current DoD philosophy, resource development is not considered a core DoD mission and should be left to the private sector. In addition, private developers can take advantage of tax credits, and they value renewable energy credits (RECs) more highly than the Army does. As a result, letting the developers claim tax credits and retain RECs, if available, will reduce the cost of energy to the installation if the developer is selling power from the project to the site.

\section{The Political and Economic Environment for Renewables at Fort Campbell}

\section{Fort Campbell Energy Characterization}

Fort Campbell is provided electricity from the Tennessee Valley Authority (TVA), which is delivered to two substations, Edgoten Substation and Screaming Eagle Substation, and distributed through an Army owned distribution system. The site consumed 289,508 MWh in FY 2009, and the total bill was \$21.1 million. 
Based on FY 2009 bills, the blended rate was calculated to be $7.3 \phi / \mathrm{kWh}$, and the marginal rate was calculated to be $4.14 \phi / \mathrm{kWh}$. The blended rate was used for base-load renewable energy resources, which are not intermittent. These resources include biomass, waste-to-energy (WTE), and geothermal. Solar and wind are intermittent resources, and cannot reliably reduce demand costs, and therefore, the marginal rate was applied to these resources.

\section{State Incentives for Renewable Project Development}

Fort Campbell is unique because it straddles two states, Tennessee and Kentucky. State incentives for renewable energy projects were examined for both states. Kentucky's renewable energy incentives provide an extra advantage when compared with Tennessee's incentives.

Kentucky's main renewable energy incentives are in the form of sales tax exemptions and a Tennessee Valley Authority (TVA) renewable energy credit (REC), while Tennessee only has a $67 \%$ exemption of property taxes for wind energy systems and the TVA REC. Therefore, unless a renewable energy facility needed to be specifically located in Tennessee to take advantage of a resource (e.g., landfill gas), it was assumed that the equipment would be sited in Kentucky.

Kentucky has a corporate tax incentive for photovoltaic units and wind but is limited to $\$ 1,000$ and thus was not included in this analysis. Kentucky exempts sales tax for solar photovoltaic, wind, biomass, and landfill gas equipment. The exemption cannot be greater than half of the investment and must be at least $1 \mathrm{MW}$ in size. Also, TVA provides a REC for solar, wind and biomass facilities under $1 \mathrm{MW}$. The credit is $\$ 0.12 / \mathrm{kWh}$ for 10 years for solar and $\$ 0.03 / \mathrm{kWh}$ for other renewable resources. Because the credit is limited to plants sized less than $1 \mathrm{MW}$, the credit was only applied to solar facilities.

These incentives are explained in detail in Appendix A.

\section{Federal Incentives for Renewable Project Development}

Federal incentives for renewable energy include investment tax credits for corporations, significantly accelerated depreciation of equipment, and production tax credits. A $30 \%$ tax credit is available for photovoltaic (PV) projects, and $10 \%$ for geothermal and biomass electricity projects, with no incentive limits. The credits may be taken on equipment placed in service prior to January 1, 2017. Wind is not eligible for the business energy tax credit. The tax basis for depreciation must be reduced by the amount of any Federal subsidy used in the financing of the eligible equipment.

Depreciation for most renewable energy equipment qualifies for significantly accelerated depreciation. For solar, wind, and geothermal, the modified accelerated cost recovery system (MACRS) provides for 5-year recovery of the cost of equipment. The 5-year recovery period does not apply to biomass or WTE equipment.

The renewable energy production tax credit (PTC), originally established in 1992, provides a tax credit for each kilowatt-hour of electricity produced. The PTC is $2.1 \phi / \mathrm{kWh}$ for wind, geothermal, and closed-loop biomass (biomass that is grown with the sole purpose of being used to generate energy) and can be taken for 10 years. The PTC is $1.1 \phi / \mathrm{kWh}$ for electricity produced from open-loop biomass and municipal solid waste (MSW) resources and can be taken for 5 years. Solar electricity generation has been excluded for equipment placed in service after December 2005. The PTC has been allowed to lapse and has then been renewed several times 
Available tax incentives reduce the first-year costs of qualified renewable projects. The lower first cost also reduces the amount of money that must be borrowed to develop a project and thus, the associated interest and carrying costs. The combination reduces the delivered cost of power if developed by a private party with a tax obligation. Government-owned projects do not benefit from tax-based incentives. All of the PPA analyses conducted in this report assume that the PTC and other tax credits will be available when the equipment is placed in service. 


\section{Results and Recommendations}

A summary of analysis results is presented in Table 3, broken down into economic (green), marginal (yellow), or uneconomic (red) projects. The underlying analyses and recommendations for each of these technologies and potential projects are provided in the following subsections.

Table 3: Summary of Fort Campbell Renewable Energy Opportunities

\begin{tabular}{|c|c|c|c|c|c|c|c|c|}
\hline & $\begin{array}{l}\text { Renewable } \\
\text { Resource and } \\
\text { Technology }\end{array}$ & $\begin{array}{c}\text { Resource } \\
\text { Estimate }\end{array}$ & $\begin{array}{l}\text { Earliest } \\
\text { Output }\end{array}$ & Figures of Merit & $\begin{array}{l}\text { Financing } \\
\text { Mechanisms } \\
\text { Evaluated }\end{array}$ & Location--Requirements & Key Assumptions & $\begin{array}{l}\text { Next Steps } \\
\text { Comments }\end{array}$ \\
\hline \multirow{2}{*}{ 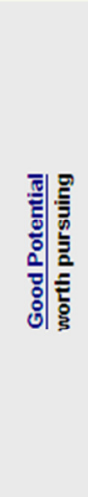 } & $\begin{array}{l}\text { Ground } \\
\text { Source Heat } \\
\text { Pump } \\
\text { (Thermal } \\
\text { Energy) }\end{array}$ & TBD & 2011 & $\begin{array}{l}\text { ECIP scenario: } \\
\text { SIR } 1.0-1.5 \\
\text { SPB } 10.4-13.4\end{array}$ & $\begin{array}{l}\text { ECIP } \\
\text { IPP } \\
\text { UESC } \\
\text { ESPC }\end{array}$ & $\begin{array}{c}\text { Adequate heat sources } \\
\text { and sinks proximate to } \\
\text { GSHPS }\end{array}$ & $\begin{array}{l}\text { There are buildings } \\
\text { that require heating } \\
\text { and potentially cooling. } \\
\text { Suitable land area and } \\
\text { soil characteristics for } \\
\text { closed loop GSHPs. }\end{array}$ & $\begin{array}{l}\text { Suite surveys to } \\
\text { determine whether } \\
\text { suitable heat sinks } \\
\text { and sources exist, } \\
\text { and to provide the } \\
\text { detailed soil } \\
\text { characterization to } \\
\text { base system design. }\end{array}$ \\
\hline & $\begin{array}{l}\text { Waste to } \\
\text { Energy }\end{array}$ & 20-27 MW & 2013 & $\begin{array}{c}\text { SIR: } 1.6-1.9 ; \\
\text { SPB: } 7.5-9.1 \text { years }\end{array}$ & IPP & $\begin{array}{l}\text { A } 5 \text {-acre site near major } \\
\text { roads, a utility } \\
\text { substation, water, } \\
\text { sewage, and an } \\
\text { appropriate industrial } \\
\text { infrastructure }\end{array}$ & $\begin{array}{l}\text { Adequate MSW for the } \\
\text { plant sized selected. } \\
50 \% \text { of tipping fees } \\
\text { available with MSW to } \\
\text { plant. }\end{array}$ & $\begin{array}{l}\text { Confirm waste } \\
\text { availability and } \\
\text { tipping fees. } \\
\text { Economics are highly } \\
\text { dependent upon } \\
\text { tipping fee available } \\
\text { from waste providers. }\end{array}$ \\
\hline 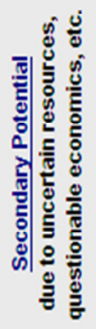 & $\begin{array}{l}\text { Biomass } \\
\text { Generation } \\
\text { Plant }\end{array}$ & $\begin{array}{c}79 \text { MW of } \\
\text { available } \\
\text { crop waste }\end{array}$ & 2013 & $\begin{array}{c}10 \% \text { IPP scenario }= \\
7.7 \text { \&/KWh break even } \\
\text { rate } \\
\text { ECIP scenario: } \\
\text { SIR } 1.2 \\
\text { SPB: } 11.1\end{array}$ & IPP & $\begin{array}{l}\text { A } 5 \text {-acre site near major } \\
\text { rods, a utility substation, } \\
\text { water, sewage, and an } \\
\text { appropriate industrial } \\
\text { infrastructure, plus } \\
\text { feedstock storage space }\end{array}$ & $\begin{array}{l}\text { Off-site crops will be } \\
\text { available for } \$ 20 \text { per } \\
\text { ton, sufficient on-site } \\
\text { storage is available }\end{array}$ & $\begin{array}{l}\text { Do not pursue this } \\
\text { technology unless } \\
\text { electric rates } \\
\text { increase. }\end{array}$ \\
\hline \multirow{3}{*}{ 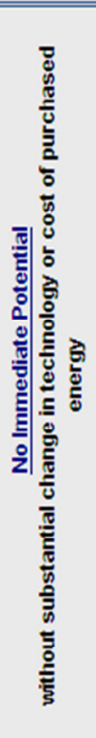 } & $\begin{array}{l}\text { Utility-Grade } \\
\text { Solar Electric } \\
\text { Power Plant }\end{array}$ & $\begin{array}{c}100 \mathrm{KW}-1 \\
\text { MW (or } \\
\text { more if } \\
\text { space is } \\
\text { available) }\end{array}$ & 2012 & $\begin{array}{c}\text { 10\% IPP scenarios = } \\
23-33 \text { c/kWh break } \\
\text { even rates } \\
\text { ECIP scenarios: } \\
\text { SIR } 0.10-0.15 \\
\text { SPB } 90+\end{array}$ & $\begin{array}{l}\mathrm{ECIP} \\
\mathrm{IPP}\end{array}$ & $\begin{array}{l}\text { Small scale: rooftops } \\
\text { (especially when } \\
\text { replacing rooftops), open } \\
\text { ground areas with } \\
\text { minimal shading or } \\
\text { concerns over } \\
\text { vandalism. } \\
\text { Large scale: near high } \\
\text { voltage transmission } \\
\text { lines, adequate open } \\
\text { space for array and } \\
\text { inverter system } \\
\end{array}$ & $\begin{array}{l}\text { Proposed project will } \\
\text { not interfere with any } \\
\text { on-site systems. }\end{array}$ & $\begin{array}{l}\text { PV via an ECIP is not } \\
\text { viable. Wait for a } \\
\text { Renewable Portfolio } \\
\text { Standard (RPS) in } \\
\text { enacted, electric } \\
\text { rates increase, or PV } \\
\text { capital costs } \\
\text { decrease. REC sales } \\
\text { are possible and } \\
\text { should be } \\
\text { considered. }\end{array}$ \\
\hline & $\begin{array}{l}\text { High } \\
\text { Temperature } \\
\text { Geothermal } \\
\text { Generation }\end{array}$ & NA & NA & NA & NA & NA & $\begin{array}{l}\text { No known high } \\
\text { temperature resource }\end{array}$ & $\begin{array}{l}\text { Nothing unless a } \\
\text { viable geothermal } \\
\text { resource is } \\
\text { discovered. }\end{array}$ \\
\hline & $\begin{array}{l}\text { Utility Grade } \\
\text { Wind Farm }\end{array}$ & $\begin{array}{c}1.5 \mathrm{MW} \\
\text { installed } \\
\text { capacity at } \\
13.5 \%\end{array}$ & 2012 & $\begin{array}{c}10 \% \text { IRR scenario }= \\
30 \% / k W h \text { break even } \\
\text { rate } \\
\text { ECIP scenario: } \\
\text { SIR -negative } \\
\text { SPB - negative }\end{array}$ & $\begin{array}{l}\text { ECIP } \\
\text { IPP }\end{array}$ & $\begin{array}{l}\text { Projects need to be } \\
\text { located within } \\
\text { approximately } 1 \text { mile of } \\
\text { existing transmission } \\
\text { lines, or new lines will } \\
\text { need to be constructed } \\
\text { and away from active } \\
\text { aifields. }\end{array}$ & $\begin{array}{l}\text { Proposed project will } \\
\text { not interfere with any } \\
\text { on-site systems. }\end{array}$ & $\begin{array}{l}\text { If incentives become } \\
\text { available or there is a } \\
\text { rate increase, the } \\
\text { feasibility of a wind } \\
\text { project should be } \\
\text { reevaluated }\end{array}$ \\
\hline
\end{tabular}

ECIP = Energy Conservation Investment Program; SIR = savings-to-investment ratio; SPB = simple payback; IPP = independent power producer; UESC $=$ utility energy services contract; ESPC $=$ energy savings performance contract 


\section{Ground Source Heat Pump Findings and Recommendations}

The cost-effectiveness of retrofitting existing heating, ventilating, and air conditioning (HVAC) systems with GSHPs on Fort Campbell was evaluated using the Facility Energy Decision System (FEDS) building energy modeling program. FEDS analyzed open-loop, horizontal closed-loop, and vertical closed-loop GSHPs using data from a 2009 PNNL data-gathering trip.

GSHPs were found to be cost-effective for a number building groups. GSHPs work well in buildings with relatively balanced heating and cooling loads because the installed capacity can be fully utilized in both the summer and winter. Although Fort Campbell has more heatingdegree-days than cooling-degree-days, many buildings at Fort Campbell have relatively balanced heating and cooling loads because of internal heat gains. Open-loop systems were found to be the most cost-effective, followed by horizontal and then vertical loop systems. Projects were identified for buildings with natural gas and central heat. All of the cost-effective GSHP projects were found in buildings that are cooled with electric package units, as shown in Table 4.

Table 4: Simple Payback Periods for Building Groups Analyzed in FEDS*

\begin{tabular}{|c|c|c|c|}
\hline \multirow{2}{*}{ Description } & \multirow{2}{*}{ Group ID } & \multicolumn{2}{|c|}{ Appropriated Financing } \\
\hline & & Open** & Horizontal \\
\hline Older Office with Warehouse & $10 \mathrm{~g}$ (Office section) & 10.4 & - \\
\hline Communications and Electronics & $23 a$ & - & 13.4 \\
\hline New Mid-Sized Barracks & $30 \mathrm{~h}$ & 11.5 & 13.2 \\
\hline Fitness Center & $80 c$ & 13.1 & - \\
\hline
\end{tabular}

* Building groups with no economically feasible projects are not included in this list

** Open-loop GSHP

$†$ Horizontal closed-loop GSHP

With ECIP funding, open-loop and horizontal closed-loop systems were found to be costeffective most often. For buildings with natural gas heating, GSHP projects have simple payback periods of 10.4 years for older warehouse/office buildings and as high as 13.4 years for communications and electronics buildings. All of the cost-effective GSHP projects are currently served by either natural gas or, in the case of building set $23 \mathrm{a}$, electric resistance heat. No costeffective retrofits were identified for buildings served by central energy plants (CEPs). No alternative financed projects proved to be cost-effective because the return on investment must be better than with ECIP funded projects. Because ECIP-funded projects already have long paybacks, it is not surprising that no alternative projects proved economic.

The building-specific results should be investigated for available land area for heat exchanger wells or loops to determine whether a GSHP is practical to install in each recommended location. Detailed results of these analyses are provided in Appendix D.

\section{Biomass Findings and Recommendations}

The availability of animal waste, cellulosic biomass, mill residue, and other industrial waste are all inadequate to consider a large biomass generation project. As shown in Table 5, crop residues were found to have marginally positive economic results. However, to achieve an SIR of 1.2, the plant size would need to be in excess of $78 \mathrm{MW}$, which is considerably larger than the 
site's load and will require arrangements to sell the excess energy. Moreover, it assumes a high degree of crop waste availability from the surrounding farms.

Table 5: Crop Reside Results

\begin{tabular}{||l|c|}
\hline Biomass Source & Wheat, Corn, and Barley Residue \\
\hline Technology & Gasification \\
\hline Plant Size & $78.6 \mathrm{MW}$ \\
\hline Feedstock Amount & 675,460 tons $/ \mathrm{yr}$ \\
\hline Total Plant Cost & $\$ 2,916.6 / \mathrm{kW}$ \\
\hline \multicolumn{1}{|c|}{ Capital Cost } & $\$ 2,916.6 / \mathrm{kW}$ \\
\hline \multicolumn{1}{|c|}{ Sales Tax } & $\$ 0.0 / \mathrm{kW}$ \\
\hline Fixed Operations and Maintenance (O\&M) Cost & $\$ 44.4 / \mathrm{kW}$ \\
\hline Variable O\&M Cost & $2.96 / \mathrm{kWh}$ \\
\hline Feedstock Cost & $\$ 20 / \mathrm{ton}$ \\
\hline \hline SIR & 1.2 \\
\hline Simple Payback & 11.1 years \\
\hline Internal Rate of Return (IRR), No Financing & $8.96 \%$ \\
\hline
\end{tabular}

Given the marginal economics, the scope of the plant, and assumptions about crop waste availability, it is recommended a crop residue plant be given a relatively low priority level. See Appendix B for more details.

\section{Wind Energy Findings and Recommendations}

Fort Campbell has a low wind energy potential, and the analysis shows that wind energy projects at Fort Campbell have poor economics given the current cost assumptions, and should not be pursued on the basis of economics at this time. If capital costs decrease, more incentives become available, and/or utility rates increase, Fort Campbell should reevaluate wind energy project economics. Alternatively, Fort Campbell could consider pursuing a demonstration project because the site has many ideal characteristics for this type of development.

With the site's wind resource and the current cost assumptions, the marginal electric rate would need to be $29.7 \not / \mathrm{kWh}$ to provide a $10 \%$ IRR. This is substantially more than the current electric rate at Fort Campbell. Using ECIP funding is not a sensible option because the SIR and paybacks are negative. These results are shown in Table 6. This analysis is detailed in Appendix F.

Table 6: Economic Assessment of Wind Power

\begin{tabular}{|c|c|c|c||}
\hline Financing Scenario & \multicolumn{2}{|c|}{ ECIP } & IPP \\
\hline Economic Factor & SIR & Simple Payback, years & Cost of Electricity at 10\% IRR $\mathbf{c / k W h}$ \\
\hline Large Wind, 1.5 MW & negative & negative & 29.66 \\
\hline
\end{tabular}




\section{Solar Energy Findings and Recommendations}

With current electricity prices and the available solar resource, PV did not prove economic. Fort Campbell's solar resource was found to be 4.4 to $6.0 \mathrm{kWh}$ solar $/ \mathrm{m}^{2} / \mathrm{day}$, depending on the mounting technology. Ground-mounted fixed-angle PV, axis-tracking PV, and buildingintegrated roof-mounted PV were all too expensive for the amount of energy produced. Table 7 shows the detailed economic results for the ECIP funding and third-party financing analyses for the PV technologies. See Appendix E for analysis details.

Table 7: Economic Results for Solar Technologies

\begin{tabular}{|c|c|c|c|c|}
\hline Solar PV System & $\begin{array}{l}\text { Ground- } \\
\text { Mounted Fixed- } \\
\text { Tilt PV }\end{array}$ & $\begin{array}{l}\text { Ground-Mounted } \\
\text { Axis-Tracking PV }\end{array}$ & $\begin{array}{l}\text { Roof-Mounted } \\
\text { CdTe PV }\end{array}$ & $\begin{array}{l}\text { Roof- } \\
\text { Mounted Si } \\
\text { PV }\end{array}$ \\
\hline $\begin{array}{l}\text { Equipment Cost Assumptions, } \\
\$ / k W\end{array}$ & 5,625 & 6,625 & 4,000 & 4,500 \\
\hline SIR & 0.12 & 0.10 & 0.15 & 0.13 \\
\hline Simple Payback, yrs & 120 & 136 & 95 & 109 \\
\hline $\begin{array}{l}\text { Cost of Electricity at } 10 \% \text { IRR, } \\
\text { c/kWh }\end{array}$ & 32.73 & 30.86 & 23.59 & 27.80 \\
\hline Variable O\&M, $\boldsymbol{c} / \mathbf{k W h}$ & 0.0 & 0.0 & 0.0 & 0.0 \\
\hline Fixed O\&M, \$/net kW & 20 & 33 & 20 & 20 \\
\hline $\begin{array}{l}\text { Federal Energy Tax Credit (a } \\
\text { credit worth a percentage of the } \\
\text { expenditures) }\end{array}$ & $30 \%$ & $30 \%$ & $30 \%$ & $30 \%$ \\
\hline Production Tax Credit, $\propto / \mathrm{kWh}$ & $12 \phi / \mathrm{kWh}$ & $12 \phi / \mathrm{kWh}$ & $12 \phi / \mathrm{kWh}$ & $12 \phi / \mathrm{kWh}$ \\
\hline
\end{tabular}

Although the economics are unfavorable, there is interest at Fort Campbell in solar demonstration projects and microgrid applications. Fort Campbell should continue to monitor the market conditions affecting solar energy, the incentives available, and the installation's energy needs so a project can be reevaluated in the future if conditions change favorably.

\section{Waste-to-Energy Findings and Recommendations}

Multiple off-site MSW scenarios showed favorable economics in the initial screening. Two municipal solid waste (MSW) projects and one landfill gas (LFG) scenario appear to support economic electricity generation at this time. A detailed economic analysis was conducted for the scenarios considered. The results are shown in Table 8. 
Table 8: Waste-to-Energy Economic Results

\begin{tabular}{|c|c|c|c|}
\hline Waste Source & $\begin{array}{c}\text { Fort Campbell, Family Housing, } \\
\text { and Bi-County Landfill }\end{array}$ & $\begin{array}{c}\text { Fort Campbell, Family Housing, } \\
\text { and Bi-County Landfill }\end{array}$ & $\begin{array}{l}\text { Bi-County } \\
\text { Landfill } \\
\end{array}$ \\
\hline Technology & Combustion & Gasification & Generators \\
\hline Plant Size & $20.4 \mathrm{MW}$ & $27.0 \mathrm{MW}$ & $3.6 \mathrm{MW}$ \\
\hline $\begin{array}{l}\text { Feedstock } \\
\text { Amount }\end{array}$ & 185,390 tons/yr & 185,390 tons/yr & $540,160 \mathrm{kcf} / \mathrm{yr}$ \\
\hline $\begin{array}{l}\text { Total Plant } \\
\text { Cost }\end{array}$ & $\$ 4,000.9 / \mathrm{kW}$ & $\$ 3,783.9 / \mathrm{kW}$ & $\$ 1,548.8 / \mathrm{kW}$ \\
\hline $\begin{array}{l}\text { Capital } \\
\text { Cost } \\
\end{array}$ & $\$ 3,847.0 / \mathrm{kW}$ & $\$ 3,638.4 / \mathrm{kW}$ & $\$ 1,414.4 / \mathrm{kW}$ \\
\hline Sales Tax & $\$ 153.9 / \mathrm{kW}$ & $\$ 145.5 / \mathrm{kW}$ & $\$ 134.4 / \mathrm{kW}$ \\
\hline $\begin{array}{l}\text { Fixed O\&M } \\
\text { Cost }\end{array}$ & $\$ 97.1 / \mathrm{kW}$ & $\$ 90.5 / \mathrm{kW}$ & $\$ 160 / \mathrm{kW}$ \\
\hline $\begin{array}{l}\text { Variable O\&M } \\
\text { Cost }\end{array}$ & $-0.9 \$ / k W h$ & $-1.0 \$ / k W h$ & $1.3 \phi / \mathrm{kWh}$ \\
\hline Feedstock Cost & $-\$ 17.5 /$ ton & $-\$ 17.5 /$ ton & $\$ 0.5 / \mathrm{kcf}$ \\
\hline SIR & 1.6 & 1.9 & 2.6 \\
\hline Simple Payback & 9.1 years & 7.5 years & 5.3 years \\
\hline $\begin{array}{l}\text { IRR, No } \\
\text { Financing } \\
\end{array}$ & $11.34 \%$ & $12.41 \%$ & $21.02 \%$ \\
\hline
\end{tabular}

Two different technologies were examined for the MSW analysis: gasification and combustion. Gasification is more efficient than combustion, but not as mature or common in commercial operation as combustion. For Fort Campbell, scenarios using gasification were more economical and had an SIR of 1.9 compared to 1.6 for combustion. However, the scale of these projects, at 20 to $27 \mathrm{MW}$ for combustion and gasification, respectively, is considerable and requires the combined waste stream of Fort Campbell, the family housing, and the Bi-County Landfill. Electricity generation with landfill gas also initially appeared to be a possible option as a 3.6MW power plant would have an SIR of 2.6. However, landfill gas is no longer available as this resource is being privately developed at the Bi-County Landfill.

For now, the MSW project is the only potentially feasible option for large-scale waste-to-energy renewable energy generation at Fort Campbell. It is recommended to proceed with the verification of assumptions and investigation into legal issues required for implementation if air quality and waste availability issues are not insurmountable. Additionally, previous attempts to establish long-term waste to energy power plants in the area have not been successful. These prior attempts may pose a hurdle to future waste to energy projects as political and community buy-in may be challenging to secure. See Appendix B for more details.

\section{Geothermal Power Findings and Recommendations}

According to existing data, Fort Campbell lacks naturally occurring hot water/steam fields and elevated temperatures at economic depths (less than 3,000 $\mathrm{m}$ ). To reach the required temperature of at least $212^{\circ} \mathrm{F}\left(100^{\circ} \mathrm{C}\right)$, drilling to a depth in excess of $3,000 \mathrm{~m}$ is required, resulting in high drilling costs.

Because the geothermal resource is inadequate to support an economic project at Fort Campbell, no immediate action should be taken. Considering the geology of the area in which Fort 
Campbell is located, it is unlikely that there will be any changes in resource availability in the near future. Detailed data and results are provided in Appendix C.

\section{Shale Gas Findings and Recommendations}

Lastly, Fort Campbell personnel are aware of the shale gas potential in areas surrounding the site, and as a result, the site requested that PNNL perform a cursory review of existing literature to determine if there may be a shale gas resource. These resources indicate that Fort Campbell is located near the southern edge of the Illinois Basin, one of North America's oldest oil and gas provinces. The Illinois Basin is a large depositional and structural basin encompassing approximately $60,000 \mathrm{mi}^{2}\left(155,000 \mathrm{~km}^{2}\right)$ and spanning across four states: Illinois, Indiana, Kentucky, and Tennessee. Recent drilling activity in the Illinois Basin has mainly been focused on shale gas produced from the New Albany Shale. The New Albany Shale is a Devonian age, hydrocarbon rich shale that underlies much of the Illinois Basin. In general, the New Albany Shale is relatively shallow in terms of oil and gas drilling (600 to 5,000 ft) and has sufficient thickness and natural fractures to accommodate accumulation of natural gas pockets. According to the Energy Information Administration's map of active shale gas plays in the United Sates (EIA 2010), Fort Campbell is located to the south of the New Albany shale gas play (Figure G2), which is the region within the Illinois basin that is recognized for having an economic quantity of gas. Additional investigations should focus on using existing published resources that could help identify the geochemical, lithologic, structural and stratigraphic conditions of the New Albany shale beneath Fort Campbell. 


\section{APPENDIX A}

\section{Business Case Analysis Approach}


Renewable Energy Opportunities at Fort Campbell, Tennessee/Kentucky Pacific Northwest National Laboratory, March 2011 


\section{Appendix A: Business Case Analysis Approach}

\section{Overall Basis for Project Economic Feasibility}

The renewable projects considered in this analysis need to compare favorably against the current commercial price of electricity to be purchased by Fort Campbell to be economically feasible. Fort Campbell obtains its electricity from the Tennessee Valley Authority (TVA).

TVA provided Fort Campbell with 289,508 MWh in FY 2009. Peak energy consumption occurred in August at 30,254 MWh, and the smallest monthly electrical consumption occurred in November. The total FY 2009 bill was \$13.0 million.

TVA charges Fort Campbell on a fixed-price basis for electricity and power. In FY 2009, TVA charged Fort Campbell 3.09 $\phi / \mathrm{kWh}$, independent of seasonality or time of use. Demand charges were $\$ 16.77 / \mathrm{kW}$, which is notably expensive. In addition to electric and demand charges, there is a variable fuel surcharge that ranged from $0.5 \phi / \mathrm{kWh}$ in July to $1.9 \phi / \mathrm{kWh}$ in November. The blended rate was calculated to be $7.3 \phi / \mathrm{kWh}$, and the marginal rate, which excludes demand charges, was calculated to be $4.1 \phi / \mathrm{kWh}$.

Solar and wind renewable energy resources would displace the direct energy $(\mathrm{kWh})$ charge, or the marginal rate. Geothermal and waste-to-energy need to compare favorably against the average cost (including demand charges), or the blended rate. The ground source heat pump (GSHP) analysis used the detailed time-of-use rate schedule to calculate operational cost savings.

Natural gas is provided by Clarksville Gas at a cost of \$7.57/MMBtu.

All but one of the analyses was conducted using the Financial Analysis Tool for Electric Energy Projects (FATE2-P) financial analysis model, described later in this appendix. The analysis for GSHPs was conducted using the Federal Energy Decision System (FEDS) model, also described in this appendix.

\section{Analytic Approaches}

In assessing the economic feasibility of renewable energy projects at Fort Campbell, Pacific Northwest National Laboratory (PNNL) generally evaluated two business case alternatives, (1) investment by an independent power producer (IPP), and (2) Energy Conservation Investment Program (ECIP) funding. These two funding sources have the best returns on Federal investments among the available alternatives. Two other funding mechanisms were examined when evaluating GSHP projects: (3) the utility energy services contract (UESC), and (4) the energy savings performance contract (ESPC).

Under an IPP scenario, an independent power producer will generally fund, construct, and operate a renewable energy facility, selling power into the competitive marketplace and/or directly to the site that hosts the energy project. This scenario is generally economic when the third-party investor can take advantage of substantial Federal and state incentives. The incentives depend on the type of renewable energy generated and may include production tax credits, investment tax credits, substantially accelerated tax depreciation of assets, reductions in sales taxes, and exemption from property tax.

ECIP is one standard DoD approach for making energy efficiency and renewable energy investments using Federally appropriated funding. ECIP investment awards are made based 
upon savings to investment ratio (SIR) and simple payback criteria. ECIP funding is limited, and is awarded on a competitive basis within the Army-only the most economic projects can be assured funding. The approach used in the analyses follows the Federal life-cycle cost (LCC) methodology and procedures in 10 CFR, Part 436, Subpart A. The LCC calculations are based on the Federal Energy Management Program (FEMP) discount rates and energy price escalation rates updated on April 1, 2009.

The UESC and ESPC are similar approaches, where a third party invests in an energy project on the Federal facility in return for a share of the energy savings that result. The major difference is that under an UESC, the third party is a utility - generally the utility providing energy to the Federal facility. Under an ESPC, the investment party is a non-utility, generally an engineering firm that specializes in energy projects. Under UESC and ESPC, the third party must be repaid out of each year's operational dollars, and the investment must be repaid within the lifetime of the asset. Generally, UESC is more feasible than ESPC because utilities can obtain capital less expensively than can the ESPC contractor. But not all utilities fund UESC projects and the types of projects funded may be limited, opening the door for ESPC. The UESC/ESPC cannot generally capture depreciation or tax incentives that would be afforded an IPP.

\section{Independent Power Producer Assumptions}

In addition to capital and operating costs, project feasibility for the IPP is dependent on Federal and state tax incentives, interest rates, inflation rates, and required rates of return discussed in the following sections.

\section{Federal Incentives for Renewable Energy}

Federal incentives for renewable energy include investment tax credits for corporations, significantly accelerated depreciation of equipment, and production tax credits. Combining the incentives with attractive market prices can, in certain cases, lead to feasible renewable energy projects.

\section{Tax Credits}

A $30 \%$ business energy tax credit (investment tax credit) is available for photovoltaic and smallscale wind projects; a $10 \%$ credit is available for geothermal and biomass electricity projects (DSIRE 2010a). Large-scale wind, geothermal and biomass electricity generation projects also qualify for production tax credits (JCT 2007), but both cannot be taken at the same time. Financial crisis emergency legislation lengthened the investment tax credit period by 8 years to January 1, 2017 from its previous end of December 31, 2008 (H.R. 1424 2008). There are no incentive limits for solar and geothermal electric.

\section{Depreciation}

Most renewable energy equipment qualifies for significantly accelerated depreciation using the modified accelerated cost recovery system (MACRS). According to 168(e)(3)(B)(vi), most renewable energy production facilities would qualify for 5-year accelerated depreciation (U.S. Treasury 2009a). 
Table A-1 provides the depreciation rates used in the model for 5-year property. The rates reflect the use of the 3/4-year convention. The basis is reduced by $50 \%$ of any energy investment tax taken (JCT 2007). The tax basis for depreciation must also be reduced by the amount of any Federal subsidy used in the financing of the eligible equipment (26 USC $\S 48$ ).

Table A-1: MACRS Depreciation Rates for Renewable Energy Projects

\begin{tabular}{||c|c|c|c|c|c||}
\hline \hline Year 1 & Year 2 & Year 3 & Year 4 & Year 5 & Year 6 \\
\hline $35 \%$ & $26 \%$ & $15.6 \%$ & $11.01 \%$ & $11.01 \%$ & $1.38 \%$ \\
\hline
\end{tabular}

\section{Production Tax Credits}

The renewable energy production tax credit (PTC) provides a per-kWh-produced tax credit for electricity generated. The PTC is $2.1 \% / \mathrm{kWh}$ in 2009 for wind, geothermal, and closed-loop biomass (biomass that is grown with the sole purpose of being used to generate energy) and can be taken for 10 years. The PTC is $1.1 \notin / \mathrm{kWh}$ for electricity produced from open-loop biomass and municipal solid waste resources and can be taken for 5 years (U.S. Treasury 2009b). The PTC for solar electricity generation has been excluded for equipment placed in service after December 2005 (H.R. 6111 2006). The PTC has been allowed to lapse and then been renewed several times. All of the analyses assume it will be available when the equipment is placed in service.

\section{Kentucky and Tennessee-Specific Incentives and Taxes}

Fort Campbell lies across four counties in Kentucky and Tennessee. We assumed the facilities would be in Christian County, Kentucky or Montgomery County, Tennessee. Unless a renewable energy facility needed to be specifically located in Tennessee to take advantage of the resource or the resource was significantly better in Tennessee, we assumed that the equipment would be sited in Kentucky. Kentucky's renewable energy incentives provide an extra advantage when compared with Tennessee's incentives. Kentucky's main renewable energy incentives are in the form of sales tax exemptions and a Tennessee Valley Authority (TVA) Renewable Energy Credit (REC), while Tennessee only has $67 \%$ exemption of property taxes for wind energy systems (DSIRE 2010e) and the TVA REC (DSIRE 2010f).

Kentucky has a corporate tax incentive for photovoltaic units and wind but is limited to $\$ 1,000$ and thus was not included in this analysis (DSIRE 2010b). Kentucky exempts sales tax for solar photovoltaic, wind, biomass, and landfill gas equipment. The exemption cannot be greater than half of the investment and must be at least $1 \mathrm{MW}$ in size (DSIRE 2010c).

The TVA provides a REC for solar, wind and biomass facilities under $1 \mathrm{MW}$. The credit is $\$ 0.12 / \mathrm{kWh}$ for 10 years for solar and $\$ 0.03 / \mathrm{kWh}$ for other renewable resources. Because the credit is limited to plants sized less than $1 \mathrm{MW}$, the credit was only applied to solar facilities (DSIRE 2010d, TVA 2010).

Kentucky income tax is 6\% (KDOR 2010). The sales tax for waste-to-energy plants is $4 \%$ (KDOR 2008). Property taxes are assessed on $100 \%$ of assessed value and assumed to be $1.38 \%$ based on Christian County information (CCK 2009).

For sites in the Tennessee, the only incentive used is the TVA renewable energy credit described above. Wind on the Tennessee portion of fort was not modeled because the Kentucky incentives 
were at least as good and wind is generally uneconomic when the resource is rated at class 1 , as it is at Fort Campbell. Tennessee has several other green incentives, but they relate to the manufacture of green facilities or facilities that manufacture green energy products, such as solar photovoltaic cells, and do not directly provide tax incentives to developers of renewable energy facilities such as wind, solar, and biomass/waste-to-energy (TDOR 2009).

Tennessee has a franchise tax, which is the equivalent of a state property tax on real property or net worth. The franchise tax is $0.25 \%$ of net worth. The Tennessee income tax is $6.5 \%$ and is called an excise tax. The sales and use tax in Tennessee is between $9.25 \%$ and $9.75 \%$ with the Montgomery County at 9.5\% (TDOR 2009, MCAB 2009). Tennessee splits the taxation of property into real property and tangible personal property for property taxation purposes. Each type of property is assessed at a different percentage of fair market value. The total assessed value is based on $40 \%$ of fair market value for real property, while tangible property is assessed at $30 \%$ of value. We assumed that Tennessee would rule a portion of all the facilities as tangible personal property rather $100 \%$ real property. It was assumed that landfill gas plants would be $30 \%$ real and $70 \%$ tangible property providing a composite effective rate of 0.944 cents per $\$ 100$ of value until plant equipment has depreciated to zero. The property tax rate for Montgomery County is $2.88 \%$ before being adjusted by assessed valuation percentages (MCAP 2010).

\section{Other Independent Power Producer Assumptions}

The minimum after-tax internal rate of return (IRR) used in the analysis of IPP opportunities was $10 \%$. The typical after-tax rate of return for most third-party developers is closer to $15 \%$, but there appears to be a suite of renewable energy developers willing to accept a lower return. Both costs and prices were assumed to escalate with an inflation rate of $1.2 \%$.

\section{Energy Conservation Investment Projects}

The assumptions for ECIP are driven by FEMP. Table A-2 lays out the discount rates underlying the model as of April 2009. The real and nominal rates for DOE/FEMP imply a 1.2\% inflation rate. New discount rates were obtained from Rushing and Lippiatt (2009).

Table A-2: Discount Rate Assumptions in the ECIP Model

\begin{tabular}{|r|c|c|c|c|c|c||}
\hline \hline Discount Rate & $\begin{array}{c}\text { DOE } \\
\text { FEMP }\end{array}$ & $\begin{array}{c}\text { OMB 3- } \\
\text { year }\end{array}$ & $\begin{array}{c}\text { OMB 5- } \\
\text { year }\end{array}$ & $\begin{array}{c}\text { OMB 7- } \\
\text { year }\end{array}$ & $\begin{array}{c}\text { OMB 10- } \\
\text { year }\end{array}$ & $\begin{array}{c}\text { OMB 30- } \\
\text { year }\end{array}$ \\
\hline Real & $3.0 \%$ & $2.1 \%$ & $2.3 \%$ & $2.4 \%$ & $2.6 \%$ & $2.8 \%$ \\
\hline Nominal & $4.2 \%$ & $3.3 \%$ & $3.5 \%$ & $3.6 \%$ & $3.8 \%$ & $4.0 \%$ \\
\hline
\end{tabular}

\section{FATE2-P Model Description}

The FATE2-P (Financial Analysis Tool for Electric Energy Projects) financial analysis model was used to evaluate the feasibility of renewable energy projects at Fort Campbell. The spreadsheet model was developed by Princeton Economic Research, Inc. and the National Renewable Energy Laboratory for the U.S. Department of Energy. FATE2-P can be used to develop pro forma financial statements for a utility using a revenue requirements approach or an IPP using the discounted rate of return approach. Both approaches are diagrammed in Figure A1. Other models produce very similar results given the same inputs. The revenue requirements approach follows a cost-based utility revenue requirements analysis, and the IPP approach uses a 
market-based discounted cash flow return. The FATE2-P model has been updated by PNNL to include the Military Construction (MILCON) ECIP Module in addition to the rate of return methodology. The model has been used to model improved technology designs, resource variability, and favorable tax treatment on renewable energy products. The advantage this model has over other models is that it is already suited for handling all of the renewable energy technologies in this study through one model, thus providing results on a comparable basis across all technologies.
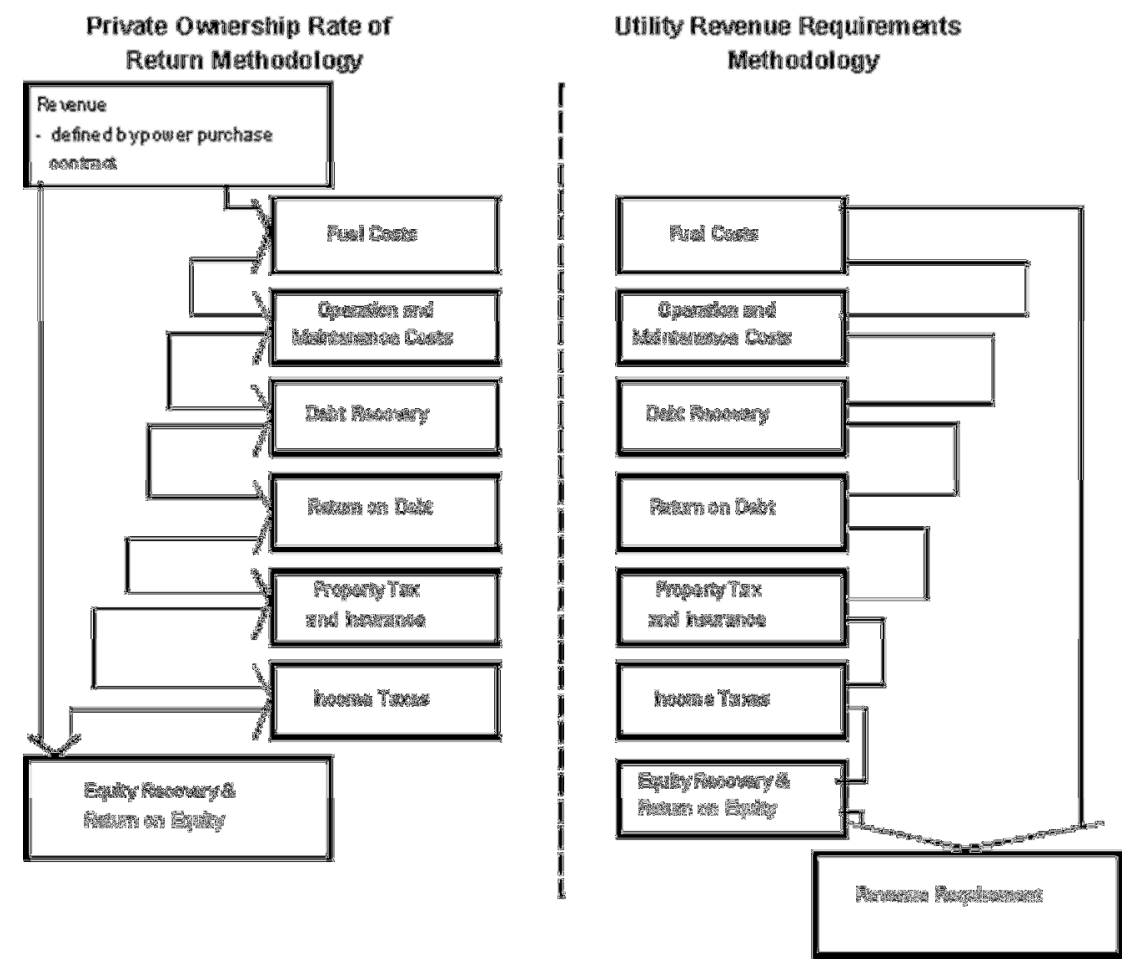

Figure A-1: FATE2-P Methodology

\section{Private Ownership Rate of Return Methodology}

The Private Ownership Rate of Return Module (IPP) develops an annual after-tax cash flow based on the revenues defined in the power purchase contract and costs associated with constructing and operating the generation facility. The goal of this approach is to capture the relevant investment costs after-tax and compare them with the net cash flow from the after-tax investment over time. The model contains sections to capture the relevant costs of construction, including the debt and equity capital accumulation to purchase the investment and the associated payback of debt and equity capital. In addition, the model has sections associated with revenue generation, cash flow, an income statement, and associated statements to calculate tax liabilities to capture after-tax cash flow. The financing section includes several pertinent sections including sources and uses, construction and debt accumulation, reserve funds requirements, debt schedule, amortization of debt fees, and debt service coverage ratios.

$\checkmark$ The Sources and Uses of Funds section shows the allocation of construction funds between components and sources of those funds. Uses of funds include construction 
cost, AFUDC (allowances for funds used during construction), and underwriters' fees for both debt and equity.

$\checkmark$ The construction and debt accumulation statement is capable of handling a 6-year construction period starting at any date. Any construction draw schedule can be used for 1 to 6 years. An equal percentage draw schedule for each year of any given construction length is the default.

$\checkmark$ The model contains major maintenance and debt-service reserve funds. Both types of accounts generate interest income that becomes a part of the income statement through a drawn-off interest calculation. The model does not currently calculate a working capital reserve account. Such an account would add interest costs to the cost statement in addition to the interest costs on the capital investment.

$\checkmark$ The debt schedule allows three types of financing: level payment, bullet, and customized. Level payment is customary for projects that have adequate cash flow to satisfy debt coverage payments and are of short duration. Customized is required when certain years fall below the minimums set by the investment banking industry.

$\checkmark$ Cash flow statements can be constructed for up to 30 years of revenue generation plus the 6-year construction time frame.

$\checkmark$ The revenue module contains a variable capacity factor that must be filled in by the analyst to capture depletion of the geothermal fields or the capacity of wind or the other renewable energy resources. This section also allows for secondary energy by-product credits (such as for steam if it has value), and up to six different types of subsidy payments, if available. The model also accepts after-tax production credits, if available, and includes interest on reserves.

$\checkmark$ Cash expenses statements include standard operations and maintenance (O\&M) costs (both fixed and variable), general and administrative (G\&A), insurance, and land fees. There is major maintenance expense along with a reserve fund dedicated to covering the major maintenance when it occurs. Up to two different fuel costs can be entered. There is also an entry for royalty fees associated with geothermal.

$\checkmark$ The earnings statement in this model calculates earnings and taxes based on a tax table. Operating income is calculated by subtracting cash and operating expenses from revenue, as described in the section above. Taxable income is determined by subtracting cash and non-cash expenses such as interest, depreciation, amortization of fees, IDC (interest during construction) and depletion allowances. Taxes paid and tax credits received are netted and after-tax book income is calculated. The net taxes paid become a part of the cash flow.

$\checkmark$ The model includes straight-line and MACRS depreciation approaches, with mid-quarter convention depreciation tables. Straight-line allows for the calculation of book basis value of assets and liabilities, while MACRS allows for the taxable basis of the investment.

$\checkmark$ The model amortizes debt-related fees over 15 years and equity organizational fees over 5 years. Equity tax advice is expensed in the first year, and equity broker fees are excluded. 
$\checkmark$ The model calculates depletion allowances on geothermal projects. The model also depletes certain AFUDC when appropriate.

$\checkmark$ Income tax and other tax statements are prepared for Federal and state taxes paid as well as tax credits earned. Tax calculations include excise taxes, Federal, state and local taxes. Depreciation calculations used to capture after-tax cash flow can use either straight-line or MACRS. There is also a section to incorporate local property taxes and special tax assessments.

$\checkmark$ The assumptions section is fairly extensive and covers construction costs, debt acquisition, equity acquisition, capacity factors, fixed and variable O\&M inputs, financial factors such as interest rates, G\&A expenses, real escalation in O\&M charges, unfired fuel assumptions, byproduct credits, asset life, inflation rates, tax rates, property tax rates, insurance, investment tax credits, AFUDC, local gross receipts tax, and special property tax assessments.

$\checkmark$ Total plant cost (overnight) is divided into: sales tax; rotor, gearbox, generator; tower and civil work; controls, transformer, interconnect; design/engineering; permitting/environmental, construction labor and supervision; contingency; home office overhead; real escalation in construction cost; miscellaneous depreciable cost (last year of construction); sales tax on miscellaneous depreciable cost; land cost; and startup cost.

\section{ECIP Module}

The FATE2-P model also includes a life-cycle cost module based on the Buildings Life-Cycle Cost (BLCC) model (produced by the National Institute of Standards and Technology) and a MILCON ECIP module, which in turn fills out Form 1391. The ECIP module currently reflects 2009 forecast discount and inflation rates. The ECIP module provides values for first-year savings, simple payback, total discounted operational savings, SIR, and adjusted IRR.

\section{The Facility Energy Decision System (FEDS) Model}

FEDS is a building energy modeling software developed by PNNL to support the economic analysis of efficiency technologies at large, multi-building sites. Building characteristics are entered into the model using as much detail as possible, and the model uses the given information to make inferences for the remaining characteristics. Multiple sets of building data can be entered into the same model, so that an entire site can be represented at once. The optimization cycle uses data about the location of the site and the energy prices entered into the model to determine cost-effective retrofits for each set of building data, and to calculate costs and savings. The suggested retrofits can range from lighting to building envelope to heating and cooling, covering all aspects of a building's energy use and considering interactive effects. In addition, the model can be adjusted to consider just one type of retrofit. In this analysis, GSHPs were the only technology analyzed using FEDS at Fort Campbell.

\section{Business Case Analysis Sources of Information}

Christian County Kentucky (CCK). 2009. “2009 Tax Rates.” Accessed 5/26/2010 at http://www.christianpva.com/ 
Commonwealth of Kentucky (KDOR). 2008. "Kentucky sales and use tax instructions." Department of Revenue, 51A205 (7-08) Accessed on May 26, 2010 at http://revenue.ky.gov/forms/cursalefrm.htm

Commonwealth of Kentucky Department of Revenue (KDOR). 2010. "Corporation Income Tax." Accessed at http://revenue.ky.gov/business/corptax.htm

DSIRE. 2010a. Federal Incentive/Policies for Renewables and Efficiency: Business Energy Investment Tax Credit (ITC). Accessed April 23, 2010 at http://www.dsireusa.org/incentives/incentive.cfm?Incentive_Code=US02F\&re=1\&ee=1 (last update June 10, 2009).

DSIRE. 2010b. Kentucky: Incentives/Policies for Renewables and Efficiency." Accessed May 26, 2010 at http://www.dsireusa.org/incentives/index.cfm?re=1\&ee=1\&spv=0\&st=0\&srp=1\&state=KY

DSIRE. 2010c. Kentucky: Incentives/Policies for Renewables \& Efficiency: Sales Tax Exemption for Large-Scale Renewable Energy Projects. Accessed May 26, 2010 at http://www.dsireusa.org/incentives/incentive.cfm?Incentive_Code=KY26F\&re=1\&ee=1 (last review November 13, 2009).

DSIRE. 2010d. Kentucky: Incentives/Policies for Renewables \& Efficiency: TVA - Generation Partners Program. Accessed May 26, 2010 at http://www.dsireusa.org/incentives/incentive.cfm?Incentive_Code=KY01F\&re $=1 \&$ ee $=1$ (last review June 24, 2010).

DSIRE. 2010e. Tennessee: Incentives/Policies for Renewables \& Efficiency: Wind Energy Systems Exemption. Accessed August 10, 2010 at http://www.dsireusa.org/incentives/incentive.cfm?Incentive_Code=TN03F\&re=1\&ee=1 (last review October 5, 2009).

DSIRE. 2010f. Tennessee: Incentives/Policies for Renewables \& Efficiency: TVA - Generation Partners Program. Accessed May 26, 2010 at http://www.dsireusa.org/incentives/incentive.cfm?Incentive_Code=TN02F\&re=1\&ee=1 (last review June 24, 2010).

H.R. 1424. 2008. Emergency Economic Stabilization Act of 2008. Enrolled Bill. http://www.govtrack.us/congress/billtext.xpd?bill=h110-1424.

H.R. 6111. 2006. Tax Relief and Health Care Act of 2006 (Enrolled as Agreed to or Passed by Both House and Senate). Title II, Section 201. Summary available at http://www.govtrack.us/congress/bill.xpd?bill=h109-6111\&tab=summary.

JCT - Joint Committee on Taxation. 2007. Description of the Chairman's Modification to the Provisions of the "Heartland, Habitat, Harvest and Horticulture Act of 2007" (JCX-96-07). Available at http://www.jct.gov/publications.html?func=select\&id=19.

Montgomery County, Tennessee Assessor of Property (MCAP). Ca 2010. "Calculating Property Tax." Accessed August 10, 2010 at http://www.montgomerycountytn.org/County/assessor/calculate.aspx 
Montgomery County, Tennessee Department of Accounts and Budgets (MCAB). August 2009. "Montgomery County Tax Rates." Accessed August 10, 2010 at http://www.montgomerycountytn.org/county/account_budget/taxrates.aspx

Rushing, Amy S and Barbara C Lippiatt. 2009. Energy Price Indices and Discount Factors for Life-Cycle Cost Analysis - April 2009. NISTIR 85-3273-23 (Rev. 5/09). U.S. Department of Commerce, National Institute for Standards and Technology, Washington D.C.

Tennessee Department of Revenue (TDOR). Ca 2009. "Tennessee Tool Kit: A Guide to Programs Aimed at Help Communities Create Higher Skilled, Better Paying Jobs." Accessed August 10, 2010 at http://tnecd.gov/multimedia_center/ecdpub.html

TVA incentive 12 cents/kWh for 10 years for renewables, limited to $999 \mathrm{~kW}$. Tennessee Valley Authority (TVA). 2010. "Generation Partners ${ }^{\text {SM }}$." Accessed 7/27/2010 at http://www.tva.com/greenpowerswitch/partners/

United States Code. "26 USC § 48. Title 26. Internal Revenue Code. Subtitle A - Income Taxes. Chapter 1 - Normal Taxes and Surtaxes. Subchapter A - Determination of Tax Liability. Part IV - Credits Against Tax. SubPart E - Rules for Computing Investment Credit.

United States Code Service. 2006. "16 USC § 796 (2006). Title 16 - Conservation. Chapter 12-Federal Regulation and Development of Power. Subchapter 1 - Regulation of the Development of Water Power and Resources. Definitions. 2006.

United States Code Service. 2006. "26 USC § 168 (2006). Title 26. Internal Revenue Code. Subtitle A - Income Taxes. Chapter 1 - Normal Taxes and Surtaxes. Subchapter B Computation of Taxable Income. Part VI - Itemized Deductions for Individuals and Corporations.

U.S. Treasury - United States Department of the Treasury. 2009a. Publication 946: How to Depreciate Property. Internal Revenue Service. Washington, D.C. Accessed June 2010 at http://www.irs.gov/app/picklist/list/publicationsNoticesPdf.html (last updated April 26, 2010).

U.S. Treasury - United States Department of the Treasury. 2009b. Form 8835: Renewable Electricity, Refined Coal, and Indian Coal Production Credit. Internal Revenue Service. Washington, D.C. Accessed June 2010 at http://www.irs.gov/pub/irs-pdf/f8835.pdf (last updated 2009). 
A-10

Renewable Energy Opportunities at Fort Campbell, Tennessee/Kentucky Pacific Northwest National Laboratory, March 2011 


\section{APPENDIX B}

Analysis of Biomass and Waste-to-Energy Opportunities 
Renewable Energy Opportunities at Fort Campbell, Tennessee/Kentucky Pacific Northwest National Laboratory, March 2011 


\section{Appendix B: Analysis of Biomass and Waste-to-Energy Opportunities}

\section{Biomass and Waste-to-Energy Technology}

The term "biomass" refers to renewable fuels used for power production that include agricultural waste, forest and wood processing waste, animal waste, industrial waste, dedicated biomass crops, and methane from landfills and wastewater treatment plants. Waste-to-energy (WTE) is similar, but includes municipal solid waste (MSW) and construction and demolition (C\&D) waste as fuel sources. These feedstocks qualify as renewable sources for Energy Policy Act of 1992 (EPAct) compliance purposes, but some states and alternative goals have different feedstock requirements. While biomass and WTE projects may be different in terms of their fuel sources, fuel collection modes, and fuel cost profiles, ultimately, the energy production often relies on similar technologies.

The primary technologies for producing electricity rely on steam turbines, gas turbines, or combined cycle turbine generators. Generators are energized by steam produced from direct combustion of raw material, or a synthetic gas (syngas) produced through anaerobic digestion or gasification. Direct combustion and anaerobic digestion technologies are mature and have been proven commercially. Gasification technologies are newer to the market, but are promising based on a number of successful installations. Anaerobic digestion is widely used but primarily for smaller applications in rural and municipal projects rather than large commercial installations.

Combustion systems burn biomass to produce steam in a boiler, turning a turbine connected to a generator. This method of producing electricity is quite inefficient, at about 20 to $30 \%$. In these systems, combustion products tend to form deposits on the heat transfer surfaces, increasing maintenance requirements and decreasing the lifetime of these surfaces because of corrosion and erosion. Ash has to be collected and removed from the system. The variability of incoming feedstock in terms of its composition and moisture content can present problems in combustion systems, most notably with MSW and mixed feeds. Systems that use a more homogeneous feedstock benefit from more complete combustion, which increases efficiency and reduces combustion waste products and emissions. Various boiler designs try to address these issues.

Gasification is more efficient than combustion, but the technologies employed are not as mature or common in commercial operation. The two basic types of gasification are direct-fired (aerobic) and indirect-fired (anaerobic). Gasification uses oxygen (direct-fired systems only), steam, heat, and pressure to break down organic materials to produce syngas, which is primarily hydrogen and carbon monoxide. Syngas is cleaned to remove impurities, then is used to generate electricity in a gas turbine or fuel cell, or is used to produce transportation fuels and/or commercially valuable chemicals. For on-site syngas applications, it is important to consider who owns and maintains Fort Campbell's gas lines because existing infrastructure would ideally be used to transport the syngas. The syngas resulting from direct-fired systems has a lower heating value than the syngas from indirect-fired systems, and requires significant upgrading and processing to be used as fuel. The inorganic materials are discharged as inert solids that can often be used for another purpose. There are many types of gasification designs that use different amounts of oxygen and steam at different stages and temperatures, producing different amounts of waste heat, syngas, and solids.

B-1 Renewable Energy Opportunities at Fort Campbell, Tennessee/Kentucky Pacific Northwest National Laboratory, March 2011 
Plasma melting is one gasification process just now entering the commercial market for use with MSW. Although it has a short track record, it is worth considering because of its positive attributes for use on a military facility. The plasma melter uses a plasma torch to decompose the material being gasified, resulting in a much higher temperature and more complete reaction. This new technology produces only syngas from the organics, molten metal from any metals, and a hard glass-like substance from the inorganics. Gaseous emissions are released and scrubbed to remove pollutants, and the solid waste can be sold and used for other commercial purposes, such as construction material. Ash collected from syngas cleaning can be fed back into the plasma melter. Hazardous materials can also be gasified in this process, sealing the toxic substances into the solid waste with no potential for leaching (EvTEC 2002).

Digesters tend to be smaller systems and are typically used just for biomass. They are usually located at the biomass source, such as farms with significant amounts of animal manure and wastewater treatment facilities. Digesters break down biomass in warm, wet environments to produce methane, which can be captured as fuel for generating electricity. Aerobic digesters are common in developing countries for production of heating and cooking fuel in rural areas. Anaerobic digesters limit the amount of oxygen in the gasification process, producing gas with a higher concentration of methane, which is better for power production. Because of the smaller size of digester systems, electricity is typically generated using fuel cells, microturbines, or reciprocating engines.

Methane is also produced through anaerobic digestion in landfills as the garbage underground breaks down. Historically, it has been left in the ground, but the risk of fire and greenhouse gas emissions has led the Environmental Protection Agency (EPA) to require landfills to remove the methane. The methane could be used in an electricity generation system if the economics are positive. The most economic opportunities for landfill methane capture and use are in cases where the landfill already has a collection system in place, is active or recently closed (methane production tapers off as landfills age), and has sufficient waste (typically at least 1 million tons) to generate a significant amount of methane. The landfill must be lined as well, to prevent water intrusion into the landfill that stifles digestion of the waste and methane production and to prevent the methane from migrating into the surrounding soil. New landfills are typically lined by regulation; many older ones are not. Methane production even from large landfills is relatively low; as a result, power facilities that use it are typically small systems located on-site using fuel cells, microturbines, or reciprocating engines.

For all of these technologies, except landfill gas, a power plant will require feedstock storage space, feedstock preparation equipment, feed equipment, processing equipment, product cleaning and collection equipment, electricity generation equipment, ash and waste storage space, water for steam and cooling, and emissions control equipment. The specific infrastructure and space required for each of these depends on the type of feedstock and process application, the amount of feedstock used, and existing site conditions. As an example, one plasma gasification project evaluated could process 250 tons of MSW per day in an 80-foot by 175 -foot area, not including storage space. However, permanent systems with infrastructure typically need up to 5 acres (excluding feedstock storage).

Some feedstocks require year-round storage, because they are only available seasonally (e.g., crop residue); some feedstocks are available almost continuously and require less storage space

B-2 Renewable Energy Opportunities at Fort Campbell, Tennessee/Kentucky Pacific Northwest National Laboratory, March 2011 
(e.g., MSW). A feedstock available continuously may need about 20 days of fuel stored in case of supply interruption, which can use about 40 acres of land, depending on the overall size of the plant. Most plants only store 3 to 5 days of fuel on-site, requiring about 4 to 5 acres. Feedstocks available only once or twice a year will need hundreds of acres of land for storage. Some feedstocks can be compressed into uniform-sized pellets to simplify storage, transport, and combustion. However, the pelletization can add $20 \%$ to fuel costs. Storage areas may have to be located some distance away from the plant because of site constraints, but nearby storage is preferred to reduce operational costs.

Emissions control requirements depend upon the process used and current regulations affecting the site. Some gasification processes (with gas scrubbers) produce no criteria pollutants, such as $\mathrm{SO}_{\mathrm{X}}$ and $\mathrm{NO}_{\mathrm{X}}$. However, air emissions are inevitable if the resulting syngas is burned in a conventional power generator. Consideration of emissions will have to be made regarding the approach to any proposed project. Plants owned and operated by third parties will qualify for separate permitting, so that may be the best opportunity for Fort Campbell.

The capital cost of biomass plants ranges from about $\$ 1,500$ to $\$ 7,000 / \mathrm{kW}$, depending upon scale and specific technologies used (Aabakken 2006). Smaller projects cost much more, resulting in higher energy costs, while larger projects cost less per $\mathrm{kW}$, resulting in more affordable energy costs. Direct combustion technologies tend to be both larger and less capitalintensive than those based on syngas. Digesters tend to have a higher unit cost, primarily because of their smaller size. Operation and maintenance $(\mathrm{O} \& \mathrm{M})$ for digesters is also more expensive, costing about $2.0 \notin / \mathrm{kWh}$, compared to about $1.0 \phi / \mathrm{kWh}$ for combustion plants (Aabakken 2006). The advantage for digesters is the low cost of fuel, which is typically free local waste (i.e., sewage sludge, manure).

Even a "free" feedstock such as crop wastes, which is not currently collected nor located at one site, does not guarantee a successful project because collection, transportation, and storage costs can be, and often are, economically prohibitive. The economics of MSW projects are typically more attractive than other biomass projects because fuel is often delivered free or even accompanied by payment in the form of a tipping fee. Most landfills are operated or franchised by a local government. Many of these derive operating revenues from fees that are added to the actual operating costs of the landfill. As a result, the tipping fee may be inflated over actual costs and therefore not an accurate representation of costs that can be avoided.

\section{Siting Considerations}

For all of these technologies, except landfill gas, a power plant will require feedstock storage space, feedstock preparation equipment, feed equipment, processing equipment, product cleaning and collection equipment, electricity generation equipment, ash and waste storage space, water for steam and cooling, and emissions control equipment. The specific infrastructure and space required for each of these depends on the type of feedstock and process application, the amount of feedstock used, and existing site conditions. Permanent systems with infrastructure typically need up to 5 acres (excluding feedstock storage).

Some feedstocks require year-round storage, because they are only available seasonally (e.g., crop residue); some feedstocks are available almost continuously and require less storage space B-3 Renewable Energy Opportunities at Fort Campbell, Tennessee/Kentucky
Pacific Northwest National Laboratory, March 2011 
(e.g., MSW). A feedstock available continuously may need about 20 days of fuel stored in case of supply interruption, which can use about 40 acres of land, depending on the overall size of the plant. Most plants only store 3 to 5 days of fuel on-site, requiring about 4 to 5 acres. Feedstocks available only once or twice a year will need hundreds of acres of land for storage. Some feedstocks can be compressed into uniform-sized pellets to simplify storage, transport, and combustion. However, the pelletization can add $20 \%$ to fuel costs. Storage areas may have to be located some distance away from the plant because of site constraints, but nearby storage is preferred to reduce operational costs.

\section{Biomass and Waste-to-Energy Analysis Approach}

The critical factor in determining feasibility for biomass energy generation is feedstock availability. There are a number of potential feedstocks that were evaluated for use at Fort Campbell. The following questions were asked about each feedstock:

$\checkmark$ Does this material exist in the surrounding region within 60 miles? (The maximum economic transport distance is assumed to be 30 to 60 miles.)

$\checkmark$ How much is available within this area, on average? Is availability constant or variable, depending on crop rotation cycles and/or market conditions?

$\checkmark$ How much is available for use as a feedstock? Availability is based on the feedstock being able to be collected and the lack of competing uses or markets. For example, wheat straw is typically left in the field to protect and rebuild the soil. If it is collected, the resulting bales may have higher value as animal bedding than as fuel, creating a competing market for what was otherwise a waste material on the ground.

$\checkmark$ How much electricity can be produced from the available biomass? This is a function of the quantity of material available, moisture content, and its relative heat value.

In this analysis, if the power potential available from a feedstock was less than $1 \mathrm{MW}$, the feedstock was considered infeasible. The narrowed list of possible feedstocks was then evaluated on a simple economic basis. Feedstock costs were estimated based on tipping fees, collection costs, transportation costs, current market rates, and other relevant information. Other operational costs and construction costs were estimated by scaling existing plant data for the primary technology types. Based on the amount of feedstock available and the size of plant required, a levelized cost of electricity was estimated for each. Fort Campbell's blended electricity cost of $7.30 \notin / \mathrm{kWh}$ was used as the target cost of electricity for this economic analysis.

PNNL staff created a new tool that supports analyses of various plant sizes, costs, and fuel sources in a generic manner. This facilitates "what if" analyses where critical information about fuel source and cost is unavailable. The result is an estimate of what power from a project would cost using available data and staff assessments for missing data. It also allows staff to reverse engineer an answer using Fort Campbell's power cost as a given. Specifically, the tool can be set up to provide an estimate of what size plant and fuel cost is needed to produce power for less than the current and projected future power rate. Data from a 2003 National Renewable Energy Laboratory (NREL) study of biomass fuels was used to initiate the analytic tool (Bain et al. 2003). The 2003 study costs were converted into 2009 dollars and scaled according to varying plant sizes following the methodology used in the study. Any size plant can be evaluated and any value can be varied to test for financial feasibility. The tool was only used for preliminary 
screening because it does not adequately address taxes, incentives, or other factors. These economic factors have a significant impact on project feasibility, especially if it is assumed the power project will not be owned and operated by the government.

If the analysis resulted in highly uneconomic estimated costs, the option was rejected. For any options that appeared to be reasonably close to cost-effective in the screening tool, further economic analysis was completed, including evaluating tax credits, other incentives, different financing options, and ranges of feedstock sources and amounts. Any risks or potential issues associated with these remaining project options were noted, to present all considerations surrounding an implementation decision. When possible, these were quantified.

\section{Biomass and Waste Resource Characterization}

The following biomass and waste types were assessed for potential as feedstocks.

- Agricultural (crop residues, animal waste, dedicated biomass crops)

- Forest (thinnings, logging slash)

- Industrial (mill residue, other industry waste)

- Waste (MSW, landfill gas, biogas or biosolids from wastewater treatment plants).

\section{Agricultural Biomass}

The States Department of Agriculture (USDA) has a database of agricultural production information by county and state. Information was gathered here about crop and livestock production.

\section{Crop Residue}

Crop residues are the plant remains in the field after harvest. Some crops have more residues than others; some, like hay, have no residues at all because the entire plant is harvested. A certain amount of residue left on the soil minimizes erosion and maintains nutrients in the soil, and can provide habitats for game animals. However, too much residue can inhibit growth of a new crop. Depending on tilling practices, climate, crop type, soil type, and slope of the land, residue may or may not be available for removal. In general, conventional till practices need more residue than no-till practices; warm wet climates need more residue than cold dry climates; corn fields need more residue than wheat fields; coarse, well-drained soils need more residue than poorly-drained, heavy clay soils; and steeper slopes need more residue than flat land. In addition, crop residue availability is dependent on competing uses, like cattle feed, and seasonal yields, which can change dramatically from year to year.

In 2008, the major crops harvested within 60 miles of Fort Campbell that left residues were wheat, corn, and barley. See Table B-1 for the number of bushels and amount of residue produced on an average annual basis (NASS 2009). Available residue for biomass energy generation will be somewhere between these values and zero. A rule of thumb is that about $30 \%$ of the residues can be collected. However, these numbers will have to be verified on a farm-byfarm basis for a more accurate analysis. 
Table B-1: Crops and Biomass Production near Fort Campbell

\begin{tabular}{||l|r|r|r|r||}
\hline & \multicolumn{1}{|c|}{$\begin{array}{c}\text { Bushels } \\
\text { Produced }\end{array}$} & $\begin{array}{c}\text { Tons Residue } \\
\text { Remaining }\end{array}$ & \multicolumn{1}{c|}{$\begin{array}{c}\text { Tons Collectable } \\
\text { Residue }\end{array}$} & \multicolumn{2}{c|}{$\begin{array}{c}\text { Potential Electricity } \\
\text { Generation }\end{array}$} \\
\hline Wheat & $15,250,150$ & 778,480 & 233,540 & $28.0 \mathrm{MW}$ \\
\hline Corn & $52,984,250$ & $1,466,270$ & 439,880 & $52.8 \mathrm{MW}$ \\
\hline Barley & 270,900 & 6,770 & 2,030 & $0.2 \mathrm{MW}$ \\
\hline Total & $\mathbf{6 8 , 5 0 5 , 3 0 0}$ & $\mathbf{2 , 2 5 1 , 5 2 0}$ & $\mathbf{6 7 5 , 4 5 0}$ & $\mathbf{7 8 . 7} \mathbf{M W}$ \\
\hline
\end{tabular}

It would cost about $\$ 10 /$ ton to transport the residues to the plant, and about $\$ 10 /$ ton for the farmer's collection effort. Therefore, crop residue feedstock cost is about $\$ 20 /$ ton. Using all crops together to gain the most benefit from economy of scale, the most cost-effective biomass option would be a gasification plant that could produce electricity at $7.7 \phi / \mathrm{kWh}$. This is slightly more expensive than Fort Campbell's rate $(7.3 \phi / \mathrm{kWh})$, making it a marginal option to pursue at this time. Detailed economic results can be found in Findings section below.

Crop residue may not be a reliable energy resource because of varying crop yields and alternative markets. Availability is dependent on seasonal yields, which can change dramatically with crop rotation, market conditions, and weather patterns. Adequate storage space is necessary to ensure that sufficient feedstock is available year-round. Availability is also dependent on competing uses, including livestock feed, which often pays almost $\$ 42 /$ ton for corn stover and over $\$ 21 /$ ton for wheat straw (Gallagher 2003), and may be located closer to the source. These potential limitations will need to be assessed before a project using crop residues is investigated further.

\section{Animal Waste}

Manure from cattle, swine, and poultry farms is generally reclaimed from animal housing and feeding areas and used as fertilizer for crops. This has become a problem because of overapplication. Bad odors and groundwater contamination are forcing farmers to find other ways to dispose of manure. Furthermore, greenhouse gas emissions are now more strictly regulated, so emissions from manure must be controlled. Anaerobic digestion technologies can turn wet manure into energy, and often can be used with existing collection and treatment systems. Poultry waste can be used directly in combustion or gasification systems because it has lower moisture content than cow or swine manure.

According to the National Agricultural Statistics Service, there are no known cattle feedlots, swine or poultry farms in the area (NASS 2009). While some pastured cattle farms may exist in the area, manure in pastures is not good feedstock material because it is not typically collected (increasing the costs and decreasing the heating value as it dries in the field). Only the manure from cattle on a feedlot can be assumed to be available for electricity generation, of which there are none within 60 miles of Fort Campbell. As a result, using manure for energy generation at Fort Campbell is not feasible.

\section{Dedicated Crops}

The most common dedicated energy crops include switchgrass, hybrid poplar, willow coppice, and other short rotation woody crops (SRWC). Energy crops are fast-growing plants that can be 
harvested for use as energy in various forms. Switchgrass is a native prairie grass that grows best in warm dry climates like the Midwest. SRWC need lots of water and do well in colder climates like the Northeast. Specifically, they need at least 16 inches of rainfall per year, or need to be located on a body of water. Using dedicated crops as biomass is an option, but they are not always a readily available resource. Rather, agricultural land where the crops can be grown is the resource to be evaluated, and the feedstock cost would be based on the cost to farm that land, harvest the resource, and deliver it to the generation plant on post.

Switchgrass, hybrid popular, and willow are the most likely energy crops that would grow well near Fort Campbell. According to De La Torre Ugarte et al. (2003), the production costs of switchgrass in the Fort Campbell region would range from \$17.21/ton to \$20.89/ton, with an average of $\$ 18.53 /$ ton. Hybrid poplar production costs would range from $\$ 24.03 /$ ton to $\$ 29.59 /$ ton, averaging $\$ 27.18 /$ ton, and willow production costs would average approximately $\$ 21.86 /$ ton. To use this material in a biomass plant on-site, a transportation cost of $\$ 10 /$ ton would be added to the production cost (there is minimal space on-site for this type of activity). In addition, compensation for the farmer would be required.

Switchgrass would be the most economic feedstock choice; at this price with no compensation, it would require a $300-\mathrm{MW}$ (at $7.30 \notin / \mathrm{kWh}$ ) gasification plant to generate cost-effective electricity, using over 2,000,000 tons of switchgrass per year and requiring over 350,000 acres of land. Because of the land area required for that feedstock production, unknown sources of feedstock, and necessary utility involvement for that size plant, dedicated energy crops are not a realistic biomass option.

\section{Forest Thinnings and Logging Slash}

Logging slash includes branches, stumps, and other material that is generated during logging practices but left behind because it is not useful to the loggers seeking large tree trunks. Once this slash is cut and left on the forest floor, it dries out, becoming good fuel for fires. It also can get in the way of machinery during replanting efforts. Sometimes it is gathered into small piles and burned in a controlled manner to reduce the risk of widespread forest fire, but this practice pollutes the air and may be restricted by air quality regulations. Instead, it can be collected and transported to a biomass facility where the emissions can be controlled and the wood waste can be used to generate energy.

There are no active wood harvesting operations on Fort Campbell. Following large storms, tree waste is frequently generated from the wooded areas on-site, and the material is collected and disposed of at $\$ 22 /$ ton, but this resource is not reliable. This material could be diverted and used for electricity generation with another woody source, but the amount collected is not significant enough to sustain its own plant.

Forested areas near Fort Campbell produced about 67,810 tons of collectable slash in 2006 (the most recent year of data available), assuming a 50\% recovery factor (Forest Service 2009). It would cost about $\$ 10 /$ ton to transport this off-site wood waste to an on-site biomass plant, and about $\$ 2 /$ ton for the collection effort, for a total of $\$ 12 /$ ton.

Using only off-site slash for a renewable biomass plant, about 7.5 MW could be generated at $10.7 \varnothing / \mathrm{kWh}$, which is not competitive with Fort Campbell's current rate. Further analysis of 
available resources showing greater quantities of available fuel feedstock would allow for a larger plant, improving economies of scale. Additional incentives, rebates, or the use of waste heat would also positively impact the economics. There are large thermal loads on-site, such as the main central energy plant (Building 3902) and the hospital that could potentially benefit from a cogeneration project. However, this analysis of thermal energy production is beyond the scope of this assessment. At the current time, it is not recommended to pursue wood waste for electricity generation only.

\section{Industrial Biomass}

Industrial biomass includes mill residue, food processing waste, textile waste, or waste from other specialized operations. There are many types of mills that use wood to produce various products, including lumber, shake and shingle, pulp, veneer and plywood, log chips, and posts, poles, and pilings. These processes generate waste in the form of sawdust and wood pieces, which are useful materials. In fact, most mill residue is currently used for fiber, fuel, or other uses.

Mills do exist in the area surrounding Fort Campbell, but the majority of the byproducts are used for other purposes, primarily fiber and fuel (Forest Service 2009). Unused mill residues with 60 miles of Fort Campbell measured approximately 3,080 tons in 2006 (Forest Service 2009). This amount of residue would generate less than $1 \mathrm{MW}$ of power. Therefore, mill residue is not an available resource. However, if Fort Campbell could provide a competitive price for the residue, some may become available. On the other hand, a competitive price would reduce the economic feasibility of using mill residues.

Lastly, there are no large industrial facilities in the Fort Campbell area that generate waste usable for biomass.

\section{Waste Biomass}

Municipal Solid and Urban Wood Waste

MSW and C\&D waste are being generated at greater rates each year while landfills are becoming full, resulting in greater hauling distances and increasing prices for waste disposal. Recycling is one way to reduce the strain on landfills; using the waste to generate energy is another. Some recyclables, like metals, must be separated out before waste is used for energy generation. All carbon-based materials, however, can be used to generate energy.

Previous commercial experiences with WTE facilities in the area have not been wholly positive and future WTE facility prospects may be influenced by the experiences with the Sumner and Davidson facilities. The Sumner county facility, which began operating in 1981, was converted to a dedicated transfer station in 2005 when GBB Services determined that the facility was no longer economic to operate (GBB 2011a). The Davidson county facility, which began producing thermal energy in 1974, had problems remaining economic and meeting emissions limits. As a result, in 2002 the local government decided to switch fuels from waste to natural gas (Metro Nashville DES 2011). The facility was demolished in 2004 before the conversion could be completed after a fire destroyed the waste receiving area and pit loading area (GBB 2011b). However, WTE technology has improved since the Sumner and Davidson county facilities were 
originally designed and constructed. These factors should be carefully considered when deciding whether to pursue a WTE facility at Fort Campbell.

In FY 2009, Fort Campbell produced approximately 10,600 tons of on-site MSW, with an additional 5,600 tons generated from family housing in CY 2009 (family housing waste collection and disposal is privatized). All MSW generated on-site, including family housing waste, is disposed of at the Bi-County Landfill. The Bi-County Landfill is located adjacent to Fort Campbell's southern border, and is the only operating landfill identified within 60 miles of the site. Waste disposed in this area totaled about 185,390 tons in 2009 , and is estimated to remain about the same in the future. These landfills are summarized, with their respective tipping fees, in Table B-2.

Table B-2: Waste near Fort Campbell

\begin{tabular}{|c|c|c|c|c|c|c|}
\hline Site & $\begin{array}{l}\text { Collection } \\
\text { Location }\end{array}$ & $\begin{array}{l}\text { Miles from } \\
\text { Campbell }\end{array}$ & $\begin{array}{l}\text { Tipping } \\
\text { Fee } \\
\text { (\$/ton) }\end{array}$ & $\begin{array}{c}\text { Assumed } \\
\text { Cost Savings } \\
\text { (\$/ton) }\end{array}$ & $\begin{array}{l}\text { Available } \\
\text { MSW } \\
\text { (tons/year) }\end{array}$ & $\begin{array}{c}\text { Potential } \\
\text { Electricity } \\
\text { Generation (MW) }\end{array}$ \\
\hline Fort Campbell & $\begin{array}{l}\text { Fort } \\
\text { Campbell }\end{array}$ & 0 & $\$ 24$ & $\$ 24$ & 10,600 & 1.16 \\
\hline $\begin{array}{l}\text { Fort Campbell } \\
\text { Family } \\
\text { Housing }\end{array}$ & $\begin{array}{l}\text { Fort } \\
\text { Campbell }\end{array}$ & 0 & $\$ 20$ & $\$ 20$ & 5.600 & 0.61 \\
\hline $\begin{array}{l}\text { Bi-County } \\
\text { Landfill }\end{array}$ & $\begin{array}{l}\text { Woodlawn, } \\
\text { TN }\end{array}$ & $<1$ & $\$ 35$ & $\$ 17.50$ & 185,390 & 27.00 \\
\hline \multicolumn{5}{|r|}{ TOTAL } & $185,390^{2}$ & 27.00 \\
\hline
\end{tabular}

${ }^{1}$ (Smith 2010, Huser 2010, Bi-County Landfill 2010)

${ }^{2}$ Fort Campbell site and family housing waste is included in the Bi-County Landfill MSW total

The assumed cost savings for the regional site is discounted $50 \%$ from the tipping fee, to account for any additional transportation needs and incentives to deliver waste to a new location.

Tipping fees fund recycling programs and other waste management operations, so the city or county would want to retain a portion of the revenue to continue operating these programs.

Fort Campbell's waste and other sources of waste in the area were evaluated as potential sources of feedstock. Depending on contracts, plans, capacity needs, and economic issues at each landfill or transfer station, none or all waste may actually be available. If these evaluated options are not feasible, additional sources should be considered. Each landfill's waste could be an option for use as feedstock, either separately or in combination with other sources, including combinations of partial waste from more than one location.

Commercial C\&D waste is often primarily comprised of concrete, asphalt, or other materials that do not break down easily, thus it is typically not available for energy generation. It is not known whether regional C\&D waste is separated into woody and non-woody materials, currently making it difficult to quantify the available material at this time. It could be diverted, separated, and used in a WTE facility if additional feedstock is needed, but there will be additional costs associated with separating the waste.

The technologies considered for waste conversion include combustion and gasification, and some options were cost-effective in the screening analysis. See the Findings section below for the economic analysis of using MSW for electricity generation.

B-9 Renewable Energy Opportunities at Fort Campbell, Tennessee/Kentucky Pacific Northwest National Laboratory, March 2011 
$\underline{\text { Landfill Gas }}$

Methane generated from decomposing waste is a combustible pollutant that must be controlled. It is typically vented or collected and flared to avoid buildup and danger of explosion. New greenhouse gas regulations are expected to require collection of landfill methane. Collected methane can be used as a fuel to generate heat or electricity.

There is one active landfill on Fort Campbell that processes only on-site generated C\&D waste, which typically does not generate significant amounts of LFG. The remaining on-site landfills have been closed for approximately 10 to 20 years, and minimal landfill gas is generated at these facilities (Rains 2010). Therefore, landfill gas is not available on-site.

The Bi-County Landfill opened in 1974 and currently has over 2 million tons of waste in place (EPA 2009). A land swap with Fort Campbell was completed in 2007 that added 356 acres of land, bringing the total land area to over 556 acres and extending the life of the landfill by over 100 years (Bi-County Solid Waste Department 2010). The landfill is located on Fort Campbell's southern border in Tennessee, approximately 15 miles from the main cantonment of the site and 5 miles from the nearest existing electrical substation. Because of the proximity of the landfill to the site, piping of the landfill gas would be minimal or not required at all, although additional electrical substations and lines may need to be constructed to deliver the electricity to the main population center. To account for any additional infrastructure requirements, a conservative piping distance of 0.5 miles was assumed for the landfill gas analysis.

Based on projected landfill gas production in the year 2011, the potential electrical power generation form a landfill gas plant is $3.6 \mathrm{MW}$ and would generate electricity at about $6.0 \phi / \mathrm{kWh}$. See the Findings section below for the detailed economic analysis. However, a project is already being developed at the Bi-county Landfill by Enerdyne Power Systems, Inc (WKRN 2009). The estimated capacity of this project is $999 \mathrm{~kW}$, and expected to begin operating in late 2011 (Brinker 2011). As a result, landfill gas is not available for Fort Campbell to use for electricity generation.

\section{Wastewater Treatment Plant Sludge}

Wastewater treatment plant (WWTP) sludge is what remains after wastewater is treated, and the clean water is returned to the ground or other body of water. It has high energy content when dried, but the drying process is energy-intensive and necessary before transportation. Sludge is similar in substance to manure; it is very watered-down and best processed on-site, where methane is generated with anaerobic digestion. Therefore, only on-site sources of sludge are reasonable to use for energy generation.

The wastewater treatment plant at Fort Campbell is privately owned. Methane was once collected from the privately owned wastewater treatment plant at Fort Campbell and used to fuel boilers, but the collectors have not been in operation for many years. Furthermore, the operators plan to convert the current wastewater treatment digesters to aerobic digesters that will only produce minimal amounts of methane. As a result, there will be no on-site sources of sludge available for use as a feedstock. 


\section{Biomass and Waste-to-Energy: Economic and Other Analysis Parameters}

Data used in this analysis were obtained from local sources when possible, and the economic assumptions were generally conservative. The assumptions are presented in the report.

However, any significant changes to important assumptions may change outcomes-

opportunities that are just barely economic in this report may no longer be economic if the values are changed significantly.

Biomass and WTE options were analyzed using Energy Conservation Investment Program (ECIP) and independent power producer (IPP) funding scenarios; an IPP is more likely to be used. Cost-effectiveness for ECIP projects is determined with savings-to-investment ratio (SIR) values (greater than 1.0), and the internal rate of return (IRR) shows whether the IPP scenario is cost-effective (greater than 10\%). The economic assumptions used to analyze each scenario, including available incentives, are listed in Table B-3. Tennessee has on average higher tax rates than Kentucky, so it was assumed that the WTE plant would be sited in Kentucky to maximize economic feasibility. Greater incentives for power plants fueled with biomass exist in Kentucky, so the crop residue project was also sited in Kentucky. It was assumed that the landfill gas project, however, would be sited in Tennessee because of the location of the Bi-County Landfill. The assumptions that vary per scenario are listed below with the results. The average cost of electricity that Fort Campbell would pay for the renewable energy was assumed to be $7.3 \phi / \mathrm{kWh}$. 
Table B-3: Economic Assumptions, constant $\$ 2010$

\begin{tabular}{|c|c|}
\hline \multicolumn{2}{|l|}{ Economic Factors } \\
\hline Inflation & $1.2 \%$ \\
\hline Interest Rate & $10.0 \%$ \\
\hline Debt/Equity Ratio & $N / A$ \\
\hline Real Discount Rate & $3.0 \%$ \\
\hline \multicolumn{2}{|l|}{ Tax Considerations } \\
\hline Federal Depreciation & MACRS \\
\hline Federal Tax Rate & $35 \%$ \\
\hline State Income Tax Rate (KY/TN) & $6.0 \% / 6.5 \%$ \\
\hline State Sales Tax $(\mathrm{KY} / \mathrm{TN})^{*}$ & $4.0 \% / 9.5 \%$ \\
\hline Property Tax Rate (KY/TN) & $1.4 \% / 0.9 \%$ \\
\hline \multicolumn{2}{|l|}{ Incentives } \\
\hline Federal Production Tax Credit & $1.1 \phi / \mathrm{kWh}$ \\
\hline State Production Tax Credit & $0.0 \phi / \mathrm{kWh}$ \\
\hline Federal Energy Tax Credit & $0 \%$ \\
\hline State Energy Tax Credit & $0 \%$ \\
\hline Utility Rebate & $\$ 0 / \mathrm{kW}$ \\
\hline \multicolumn{2}{|l|}{ Technology } \\
\hline Plant Life ${ }^{\star \star}$ & 30 years \\
\hline $\begin{array}{l}\text { Capacity Factor (basis net kW output): } \\
\text { Total System }\end{array}$ & $85 \%$ \\
\hline Real Escalation in Construction Cost & $0 \%$ \\
\hline $\begin{array}{l}\text { Misc. Depreciable Cost (last year of } \\
\text { construction) }\end{array}$ & $\$ 0$ \\
\hline $\begin{array}{l}\text { Sales Tax on Misc. Depreciation } \\
\text { Cost }\end{array}$ & $\$ 0$ \\
\hline Land Cost & $\$ 0 / \mathrm{kW}$ \\
\hline Startup Cost & $\$ 0 / \mathrm{kW}$ \\
\hline
\end{tabular}

For a landfill gas project, the gas would be piped from the Bi-County Landfill to a generation facility inside Fort Campbell's perimeter. Piping costs can vary from as little as $\$ 11 / \mathrm{ft}$ to as much as $\$ 41 / \mathrm{ft}$, depending on the size and material of the pipe (Jarnecke et al. 2006). For this analysis, a moderate estimate of $\$ 19 / \mathrm{ft}$ or $\$ 100,000 /$ mile was used for pipe materials and installation (Jarnecke et al. 2006). While piping the landfill gas may not be necessary because of the close proximity of the landfill to Fort Campbell, a piping distance of 5 miles was included in the analysis to cover any additional infrastructure needs such as electrical lines that may be required. 


\section{Findings: Biomass and Waste-to-Energy Opportunities}

The availability of animal manure, mill residue, other industrial waste, and WWTP sludge is inadequate to consider a large biomass generation project. Other potentially available biomass fuels not listed below cannot support economic electricity generation at this time.

\section{Landfill Gas}

Landfill gas utilization is the most economically promising biomass opportunity assessed for Fort Campbell. An electric generation project would have an SIR of 2.6 and an IRR of $21 \%$. Table B-4 shows the economic details for a landfill gas-to-electricity project.

Table B-4: Landfill Gas Results

\begin{tabular}{|l|c||}
\hline Gas Source & Bi-County Landfill \\
\hline Technology & Generators \\
\hline Plant Size & $3.6 \mathrm{MW}$ \\
\hline Feedstock Amount & $540,160 \mathrm{kcf} / \mathrm{yr}$ \\
\hline Total Plant Cost & $\$ 1,548.8 / \mathrm{kW}$ \\
\hline \multicolumn{1}{|c|}{ Capital Cost } & $\$ 1,414.4 / \mathrm{kW}$ \\
\hline \multicolumn{1}{|c|}{ Sales Tax } & $\$ 134.4 / \mathrm{kW}$ \\
\hline Fixed O\&M Cost & $\$ 160 / \mathrm{kW}$ \\
\hline Variable O\&M Cost & $1.3 \phi / \mathrm{kWh}$ \\
\hline \multicolumn{1}{|c|}{ Feedstock Cost } & $\$ 0.5 / \mathrm{kcf}$ \\
\hline \hline SIR & 2.6 \\
\hline Simple Payback & 5.3 years \\
\hline Internal Rate of Return (IRR), No Financing & $21.02 \%$ \\
\hline
\end{tabular}

Because a landfill gas project would reduce methane emissions, there is also the possibility of generating revenue from selling carbon credits or renewable energy credits (RECs). In addition, this project was evaluated assuming a conservative amount of gas production, rather than peak estimates. A landfill gas project is economically attractive; however, a project is already under development at the Bi-county landfill. Consequently, landfill gas is no longer available for Fort Campbell to use for electricity generation.

\section{Municipal Solid Waste}

MSW is an economic option for generating a significant amount of electricity at Fort Campbell. Fort Campbell waste and family housing waste, combined with waste from the Bi-County Landfill, was evaluated for economic feasibility as WTE projects as a combustion or gasification project. Project economics will depend on the availability and price of waste, and actual plant size, capital costs, and operating costs. Note that if a landfill gas project is pursued, this MSW may or may not be available for a WTE project at Fort Campbell. However, it represents waste that may be available from another source. The most cost-effective analyzed scenarios are presented in Table B-5. They have SIRs ranging from 1.7 to 1.9, and IRRs of about $12 \%$. However, as discussed in the Biomass and Waste Resource Characterization section, the history of WTE facilities in the Sumner and Davidson counties and current WTE activities in other parts of the state could affect the development of a WTE project at Fort Campbell. 
Table B-5: Fort Campbell, Family Housing, and Bi-County LF MSW Waste-to-Energy Results

\begin{tabular}{|c|c|c|}
\hline Waste Source & $\begin{array}{c}\text { Fort Campbell, Family Housing, } \\
\text { and Bi-County Landfill }\end{array}$ & $\begin{array}{c}\text { Fort Campbell, Family Housing, } \\
\text { and Bi-County Landfill }\end{array}$ \\
\hline Technology & Combustion & Gasification \\
\hline Plant Size & $20.4 \mathrm{MW}$ & $27.0 \mathrm{MW}$ \\
\hline Feedstock Amount & 185,390 tons/yr & 185,390 tons/yr \\
\hline Total Plant Cost & $\$ 4,000.9 / \mathrm{kW}$ & $\$ 3,783.9 / \mathrm{kW}$ \\
\hline Capital Cost & $\$ 3,847.0 / \mathrm{kW}$ & $\$ 3,638.4 / \mathrm{kW}$ \\
\hline Sales Tax & $\$ 153.9 / \mathrm{kW}$ & $\$ 145.5 / \mathrm{kW}$ \\
\hline Fixed O\&M Cost & $\$ 97.1 / \mathrm{kW}$ & $\$ 90.5 / \mathrm{kW}$ \\
\hline Variable O\&M Cost & $-0.9 \$ / k W h$ & $-1.0 \$ / \mathrm{kWh}$ \\
\hline Feedstock Cost & $-\$ 17.5 /$ ton & $-\$ 17.5 /$ ton \\
\hline SIR & 1.6 & 1.9 \\
\hline Simple Payback & 9.1 years & 7.5 years \\
\hline $\begin{array}{l}\text { Internal Rate of Return } \\
\text { (IRR), No Financing }\end{array}$ & $11.34 \%$ & $12.41 \%$ \\
\hline
\end{tabular}

\section{Crop Residue}

Using crop residues to generate a significant amount of electricity is a marginally economic option for Fort Campbell. Residues from wheat, corn, and barley were evaluated for economic feasibility as either a combustion or gasification plant. Note that the results presented are for a plant that uses all the residues assumed to be available to take advantage of economies of scale. Such a project is significantly larger than Fort Campbell's current average electric load of 45.5 MW, so alternative markets would need to be identified that would be interested in purchasing the excess electricity. As with MSW projects, economics will depend on the availability and price of the residue, and actual plant size, capital costs, and operating costs. The most costeffective analyzed scenario, a gasification project, is presented in Table B-6 and would have a SIR of 1.2, and an IRR of about $9 \%$. 
Table B-6: Crop Residue Results

\begin{tabular}{|l|c|}
\hline Biomass Source & Wheat, Corn, and Barley Residue \\
\hline Technology & Gasification \\
\hline Plant Size & $78.6 \mathrm{MW}$ \\
\hline Feedstock Amount & 675,460 tons $/ \mathrm{yr}$ \\
\hline Total Plant Cost & $\$ 2,916.6 / \mathrm{kW}$ \\
\hline \multicolumn{1}{|c|}{ Capital Cost } & $\$ 2,916.6 / \mathrm{kW}$ \\
\hline \multicolumn{1}{|c|}{ Sales Tax } & $\$ 0.0 / \mathrm{kW}$ \\
\hline Fixed O\&M Cost & $\$ 44.4 / \mathrm{kW}$ \\
\hline Variable O\&M Cost & $2.9 \mathrm{c} / \mathrm{kWh}$ \\
\hline Feedstock Cost & $\$ 20 /$ ton \\
\hline \hline SIR & 1.2 \\
\hline Simple Payback & 11.1 years \\
\hline $\begin{array}{l}\text { Internal Rate of Return } \\
\text { (IRR), No Financing }\end{array}$ & $8.96 \%$ \\
\hline
\end{tabular}

These scenarios illustrate economically feasible options available at Fort Campbell based on preliminary resource assessments. The assumptions regarding the available waste and costs are critical to the economic results. If there are any changes to these assumptions, some options may become less attractive or possibly eliminated from consideration. There are a number of economic options, however, and an MSW WTE, landfill gas, or biomass project should be considered for further investigation.

\section{Biomass and Waste-to-Energy: Next Steps}

MSW appears to be a possible economic option to generate electricity for Fort Campbell. In addition, there may be potential for biomass-based electricity generation from crop residue.

To implement a project using MSW or biomass, the following steps must occur.

- Gain support from stakeholders at Fort Campbell. Meet with all interested parties, including Bi-County Landfill and TVA as applicable, and assign roles and responsibilities.

- Quantify the amount of MSW or biomass that is actually available for use in a WTE or biomass facility, and verify what tipping fee(s) or cost will accompany the resource. Note that the soon-to-be operating landfill gas project at the Bi-county landfill could affect waste availability. Consider other feedstock sources if necessary, including wood waste.

- Determine potential locations for a WTE or biomass facility. A site is needed that is large enough for the conversion equipment, feedstock preparation, and access; has water and other utilities available; can be accessed by trucks for feedstock delivery; and can be connected to the electric grid. Note that the economics presented in this assessment are based on Kentucky tax rates; if sited in Tennessee where taxes are higher, the economics would be less favorable. 
If Fort Campbell decides it is practical to pursue any of these opportunities, a request for information should be distributed to determine whether developers are interested and can meet DoD requirements, including environmental regulations and energy costs, among others. Some additional feasibility studies may also be needed during this process.

\section{Biomass and Waste-to-Energy Sources of Information}

Aabakken, J. 2006. Power Technologies Energy Data Book - Fourth Edition. NREL/TP-62039728, National Renewable Energy Laboratory, Golden, CO.

Bain, RL, WA Amos, M Downing, RL Perlack. 2003. Biopower Technical Assessment: State of the Industry and Technology. NREL/TP-510-33123, prepared by the National Renewable Energy Laboratory and Oak Ridge National Laboratory for the U.S. Department of Energy, Washington, DC.

Bi-County Solid Waste Department. 2010. Bi-County Solid Waste Management Strategic Plan. Accessed August 2010 at http://www.montgomerycountytn.org/county/bi_county/plan.aspx

Bi-County Landfill. 2010. Telephone call between Angela Kora (Pacific Northwest National Laboratory) and Bi-County personnel, May 21, 2010, Richland, WA.

Brinker, William. 2011. Email between Angela Kora (Pacific Northwest National Laboratory) and William Brinker (Enerdyne Power Systems, Inc.), January 21, 2011, Richland, WA.

Burke, D. 2001. Dairy Waste Anaerobic Digestion Handbook. Environmental Energy Company, Olympia, WA. Accessed May 2010 at

http://www.makingenergy.com/Dairy\%20Waste\%20Handbook.pdf.

De La Torre Ugarte, DG, ME Walsh, H Shapouri, and SP Slinsky. 2000. The Economic Impacts of Bioenergy Crop Production on U.S. Agriculture. Agricultural Economic Report No. 816, prepared by the University of Tennessee Agricultural Policy Analysis Center for the U.S. Department of Agriculture, Office of the Chief Economist, Office of Energy Policy and New Uses, Washington, DC. July 2000.

EIA - U.S. Energy Information Administration. 2009. Average Heat Content of Selected Biomass Fuels. Accessed May 2010 at http://www.eia.doe.gov/cneaf/solar.renewables/page/trends/table10.html.

EPA - U. S. Environmental Protection Agency. 2009. Landfill Gas Energy Project Development Handbook. Landfill Methane Outreach Program, U.S. Environmental Protection Agency, Washington, DC. Accessed May 2010 at http://www.epa.gov/landfill/publicationstools/handbook.html.

EvTEC - Environmental Technology Evaluation Center. 2002. "Environmental Technology Verification Report for the Plasma Enhanced Melter." Civil Engineering Research Foundation. December 2002. 
Forest Service. 2009. "Forest Inventory \& Analysis Mapmaker Program on Timber Products Output Studies." United States Department of Agriculture. Accessed May 2010 at http://www.fia.fs.fed.us/program-features/tpo/ (last updated October 26, 2009).

Gallagher, P, M Dikeman, J Fritz, E Wailes, W Gauther, and H Shapouri. 2003. Biomass from Crop Residues: Cost and Supply Estimates. Agricultural Economic Report No. 819, United States Department of Agriculture, Office of the Chief Economist, Office of Energy Policy and New Uses, Washington, DC. Accessed May 2010 at http://www.usda.gov/oce/reports/energy/AER819.pdf.

Gershman, Brickner, and Bratton, Inc. (GBB). 2011a. "Review of Solid Waste Management Options, Including Use of Waste-to-Energy." Accessed January 2011 at http://www.gbbinc.com/services/quals/index.asp?service_id=15\&service_title=Waste-toEnergy\%20/\%20Alternative\%20Technologies\&qual_id=232.

Gershman, Brickner, and Bratton, Inc. (GBB). 2011b. "Demolition of Nashville Thermal Waste-to-Energy Plant." Accessed January 2011 at http://www.gbbinc.com/services/quals/index.asp?service_id=7\&service_title=Construction\%20 Waste\%20and\%20Demolition\%20Debris\%20Recycling\&qual_id=183.

Haq, Z. 2002. Biomass for Electricity Generation. U.S. Energy Information Administration, Washington, DC. Accessed May 2010 at http://www.epa.gov/solar/pdf/haq_apr20.pdf.

Huser, Richard. 2010. Fort Campbell Environmental Engineer. Site notes compiled by Bryan Russo (Pacific Northwest National Laboratory) during on-site visit, June 8, 2010, Fort Campbell, KY.

IEA - International Energy Agency. 2007. Biomass for Power Generation and CHP. ETE03, IEA Energy Technology Essentials, International Energy Agency, Paris, France. Accessed May 2010 at http://www.iea.org/textbase/techno/essentials3.pdf.

Jarnecke, D, B Garner, T Sorenson, J Jones, and J Mason. 2006. "Coiled Polyamide-11 High Pressure Gas Pipe Costs Less to Install and Operate Than Steel Stick Pipe”. Pipeline \& Gas Journal. 12(233).

Metro Nashville DES. 2011. "History of Metro Nashville District Energy System.” Accessed January 2011 at http://www.nashville.gov/des/history_of_metro.asp\#.

NASS - National Agricultural Statistics Service. 2009. “Quick Stats.” United States Department of Agriculture. Accessed May 2010 at http://www.nass.usda.gov/Data_and_Statistics/Quick_Stats/.

Rains, Jeremy. 2010. Fort Campbell Environmental Engineer. Site notes compiled by Bryan Russo (Pacific Northwest National Laboratory) during on-site visit, June 8, 2010, Fort Campbell, KY.

Research Reports International, Inc. 2007. The Use of Biomass for Power Generation in the U.S. Research Reports International, Inc., Evergreen, CO. 
Smith, CB and Cardenas-Lailhacar C. 2007. Lesser Known Energy Sources: A Study of Biogas and Tire Based Fuel. Lockheed Martin, Bethesda, MD.

Smith, Dewayne. 2010. Fort Campbell Energy Manager. Site notes compiled by Bryan Russo (Pacific Northwest National Laboratory) during on-site visit, June 8, 2010, Fort Campbell, KY.

Soil Quality National Technology Development Team. 2006. Crop Residue Removal for Biomass Energy Production: Effects on Soils and Recommendations. Technical Note No. 19, Soil Quality National Technology Development Team, Greensboro, NC. Accessed May 2010 at http://soils.usda.gov/sqi/management/files/sq_atn_19.pdf.

Stone, R and D Hilborn. 2000. Universal Soil Loss Equation (USLE). Ontario Ministry of Agriculture, Food and Rural Affairs, Ontario, Canada. Accessed May 2010 at http://www.omafra.gov.on.ca/english/engineer/facts/00-001.htm\#tab2 (last updated August 20, 2009).

The Landfill Site. 2009. Landfill Liner Leaks. Accessed May 2010 at http://www.landfillsite.com/html/landfill_liner_leaks.html (last updated March 23, 2010).

Walsh, ME, R Perlack, A Turhollow, D Ugarte, D Becker, R Graham, S Slinsky, and D Ray. 2000. Biomass Feedstock Availability in the United States: 1999 State Level Analysis. TN 37901-1071, Oak Ridge National Laboratory, Oak Ridge, TN. Accessed May 2010 at http://bioenergy.ornl.gov/resourcedata/index.html.

WKRN-TV Nashville. 2009. "Woodlawn Landfill Will Produce Electricity from Landfill Gas." Accessed January 2011 at http://www.wkrn.com/global/story.asp?s=11029785. 


\section{APPENDIX C}

\section{Analysis of Geothermal Plant Opportunities}


Renewable Energy Opportunities at Fort Campbell, Tennessee/Kentucky Pacific Northwest National Laboratory, March 2011 


\section{Appendix C: Analysis of Geothermal Power Plant Opportunities}

\section{Geothermal Power Plant Technology}

Geothermal power plants use steam from hot water reservoirs found below the Earth's surface. The steam rotates a turbine that activates a generator, producing electricity. There are three commercial types of geothermal power plants used to generate electricity (dry steam, flash steam, and binary cycle), and several newer technologies are entering the marketplace (hot dry rock and engineered geothermal systems). The type of plant depends on the state of the fluid (steam, hot water, or mixed) and its temperature. A binary cycle plant is used for this analysis because it is a proven technology and it operates on lower temperatures, which are more likely to be available.

- Dry Steam power plants use underground steam piped directly from wells to the power plant, where it passes through separators to remove small particles before it is directed into a turbine/generator unit. There are only two known underground resources of steam in the United States: The Geysers in northern California and Yellowstone National Park in Wyoming. The only dry steam plants in the country are at The Geysers.

- Flash Steam power plants use geothermal resources that produce high-temperature hot water or a combination of steam and hot water. This very hot water (reservoirs greater than $360^{\circ} \mathrm{F}$ or $182^{\circ} \mathrm{C}$ ) flows up through wells in the ground under its own pressure. As it flows upward and the pressure decreases, some of the hot water boils (flashes) into steam. The steam is then separated from the water and used to power a turbine/generator. Leftover water and condensed steam are injected back into the reservoir, making this a sustainable resource. Depending on the temperature resource, it may be possible to use a second flash tank, where more steam at a lower pressure is separated for generation (double flash plant).

- Binary Cycle power plants utilize a second fluid in a closed cycle to operate the turbine, instead of direct geothermal steam. These plants operate on water at lower temperatures of about $225^{\circ}-360^{\circ} \mathrm{F}\left(107^{\circ}-182^{\circ} \mathrm{C}\right)$. The heat from the hot water is used to boil a working fluid, usually an organic compound with a low boiling point. The working fluid is vaporized in a heat exchanger and used to turn a turbine. The water is then injected back into the ground to be reheated. The water and the working fluid are kept separated during the whole process, so there is minor or no contamination. The advantage of the binary cycle plant is that it can operate with lower temperature water by using working fluids that have an even lower boiling point than water. Binary power plants are available in smaller scales such as 200 to $1,000 \mathrm{~kW}$.

- Hot Dry Rock (HDR) geothermal production utilizes high temperature rocks found deep (several kilometers) below the surface by pumping high-pressure water down a borehole into a heat zone. The water captures the heat of the rock by traveling through fractures until it is forced out a second borehole and used to generate electricity. Once the water has cooled, it is pumped back underground to heat up again. This process is most easily utilized in locations with natural geothermal systems with existing cracks or pore spaces. 
- Engineered or enhanced geothermal systems (EGS) are similar to HDR systems. In locations where there are few cracks and connected pore spaces, or little to no cracks or connectivity, cracks can be created or enhanced. The advantage of HDR or EGS is that geothermal resources can be captured for production in non-tectonically active regions. This technology is still very new and expensive.

\section{Geothermal Energy Analysis Approach}

In the 2005 DoD Renewable Energy Assessment, the Navy's Geothermal Office was responsible for the DoD geothermal power assessment. That task was subcontracted to Innovative Technical Solutions, Inc. (ITSI). The Navy and ITSI ranked installations based on their assessment of potential. The utility grade geothermal assessment included 18 installations identified by DoD. Of those installations, five sites were found to have high potential for utility-grade systems. Fort Campbell was not found to be one of five sites with high potential for the occurrence of utilitygrade geothermal systems, nor was it among the 23 sites that have potential for direct use applications (ITSI 2003).

This analysis utilized the information available from the DoD study, in addition to other readily available sources, to determine if the following conditions exist. The following conditions demonstrate utility-grade geothermal potential:

- Existing power plant operation or developer activity,

- One or more wells tested with temperatures in excess of $212^{\circ} \mathrm{F}\left(100^{\circ} \mathrm{C}\right) \operatorname{logged}$ downhole (at depths less than $3,000 \mathrm{~m}$ ),

- Demonstrated high fluid flow rates on the order of 1,000 gallons per minute (gpm) per MW,

- Heat flow rates greater than $80 \mathrm{~mW} / \mathrm{m}^{2}$ (milliWatts per square meter),

- Other exploration data and information available $\left(\geq 212^{\circ} \mathrm{F}\left(100^{\circ} \mathrm{C}\right)\right.$ not proven $)$.

\section{Geothermal Resource Characterization}

Geothermal resources include hot springs, geysers, and underground resources of pressurized water and steam accessible via wells, as well as dry steam, hot water, hot dry rocks, and lowtemperature geothermal heat. A known geothermal resource area is an area in which the geology, nearby discoveries, competitive interests, or other indicators show that potential for extraction of geothermal steam or associated geothermal resources are sufficient to warrant consideration.

For commercial use, it is necessary to have a geothermal reservoir capable of providing hydrothermal (hot water and steam) resources with sufficiently high flow rates. For example, with a typical binary system, $1 \mathrm{MW}$ of electricity can be generated from a single well with a relatively low geothermal fluid temperature of about $230^{\circ} \mathrm{F}\left(110^{\circ} \mathrm{C}\right)$ and a high fluid production rate of 1,000 gpm (MIT 2006). However, if the fluid production is limited to only $430 \mathrm{gpm}$, generating the same $1 \mathrm{MW}$ of electricity requires a much higher fluid temperature of approximately $300^{\circ} \mathrm{F}\left(150^{\circ} \mathrm{C}\right)($ MIT 2006$)$. Obtaining both a high temperature of $300^{\circ} \mathrm{F}\left(\sim 150^{\circ} \mathrm{C}\right)$ and a high 
production rate of $\sim 1,000 \mathrm{gpm}$ could yield $2.5 \mathrm{MW}$ of electricity, resulting in a much more valuable resource.

Geothermal plants operate in regions with high heat flow rates. Heat flow values above $80 \mathrm{~mW} / \mathrm{m}^{2}$ are considered characteristic of a viable geothermal resource. Productive heat flows are generally greater than $150 \mathrm{~mW} / \mathrm{m}^{2}$ (Blackwell et al. 2003). According to the Geothermal Map of the United States (from Southern Methodist University Geothermal Lab, SMU 2004), the heat flow in the Fort Campbell region appears to be $50-55 \mathrm{~mW} / \mathrm{m}^{2}$, indicating very low potential. Fort Campbell is located near the western edge of the Interior Low Plateaus physiographic province. The Interior Low Plateaus is one of the ancient geologic provinces, characterized by low geothermal heat flow.

Utility-grade geothermal energy requires temperatures in excess of $212^{\circ} \mathrm{F}\left(100^{\circ} \mathrm{C}\right)$ at depths less than $3 \mathrm{~km}$. According to the Geothermal Temperature at Depth Map published by the Idaho National Laboratory (INL 2005), the subsurface temperature at Fort Campbell is approximately $175-195^{\circ} \mathrm{F}\left(75-100^{\circ} \mathrm{C}\right)$ at a depth of $3 \mathrm{~km}$. In addition, published temperature data for selected boreholes are available from the Southern Methodist University geothermal database (SMU 2010), and the Oregon Institute of Technology's Geo-Heat Center (GHC 2004). Geothermal gradients provided from several boreholes located within 300 miles of Fort Campbell are consistently low, ranging from 10 to $32^{\circ} \mathrm{C} / \mathrm{km}$ (Figure $\mathrm{C}-1$ ) and average approximately $18^{\circ} \mathrm{C} / \mathrm{km}$, which is far below typical geothermal gradients that exist at identified geothermal resources $\left(>50^{\circ} \mathrm{C} / \mathrm{km}\right)$.

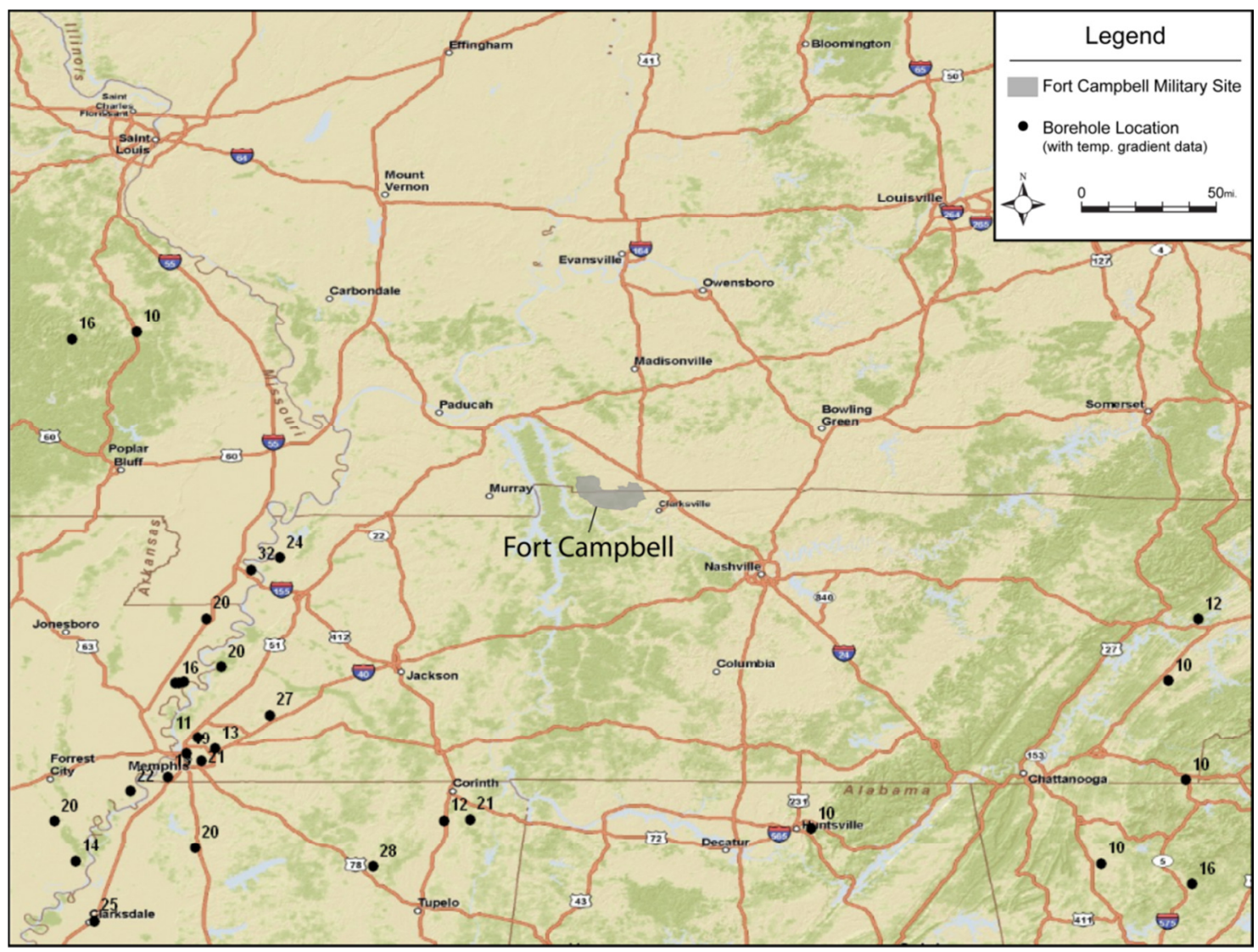

Figure C-1: Location of Boreholes with Published Geothermal Data near Fort Campbell 


\section{Geothermal Power Plants: Economic and Other Analysis Parameters}

Geothermal power costs are influenced by capital costs for land, drilling, and the physical plant. Capital costs range from $\$ 1,500$ to $\$ 4,000$ per installed $\mathrm{kW}$. Plant life spans are typically 30 to 45 years.

Capital costs include:

- Initial development work: land leasing, exploration, permitting, test well costs

- Infrastructure: roads, water supply, utilities

- Well field drilling: production wells in addition to already drilled confirmation wells

- Steam and brine gathering system: pipes and brine separation equipment

- Power plant: physical equipment for energy conversion, including substation

- Interconnection: link of the power plant substation to the transmission corridor

- Soft costs: developers' fees, overhead, financing costs, legal fees, etc.

Geothermal wells are drilled to depths of 200 to 1,500 meters for low- and medium-temperature systems. For high-temperature systems, wells are drilled 700 to 3,000 meters deep. Each well can cost between $\$ 1$ and $\$ 4$ million to drill and a geothermal field may consist of between 10 and 100 wells.

The project cost is also affected by the cost of operation and maintenance (O\&M), the amount of power generated, and the market value of the power. Operating costs range from 0.4 to $2.6 \phi / \mathrm{kWh}$ for conventional geothermal power plants (Shibaki 2003, Hance 2005). Operating plants at over $90 \%$ capacity will result in higher O\&M costs. Larger plant size means lower per$\mathrm{kWh}$ operating costs.

\section{Findings: Geothermal Power Plants}

According to existing data, Fort Campbell lacks naturally occurring hot water/steam fields and elevated temperatures at economic depths (less than $3000 \mathrm{~m}$ ). Thus, the economic calculations for geothermal energy production at the installation were not run. This assessment, which is focused on utility-scale electricity generation, did not examine the potential for direct-use applications of geothermal resources such as space heating, aquaculture, and industrial processes.

\section{Geothermal Power Plants: Next Steps}

Because the geothermal resource is inadequate to support an economic project at Fort Campbell, no immediate action should be taken. Considering the geology of the area in which Fort Campbell is located, it is unlikely that there will be any changes in resource availability in the near future.

\section{Geothermal Power Plant Sources of Information}

Blackwell, David, Kenneth Wisian, Maria Richards, Mark Leidig, Richard Smith, and Jason McKenna. 2003. Geothermal Resource Analysis and Structure of Basin and Range Systems, Especially Dixie Valley Geothermal Field, Nevada. Southern Methodist University Department 
of Geological Sciences. Dallas, Texas.

http://www.osti.gov/energycitations/servlets/purl/813485-smnwbs/native/813485.PDF.

MIT - Massachusetts Institute of Technology-led Interdisciplinary Panel. 2006. The Future of Geothermal Energy: Impact of Enhanced Geothermal Systems (EGS) on the United States in the 21st Century. INL/EXT-06-11746, prepared by MIT for the U.S. Department of Energy, Cambridge, Massachusetts. Accessed June 2010 at http://geothermal.inl.gov/publications/future_of_geothermal_energy.pdf.

Hance, Cédric Nathanaël. Factors Affecting Costs of Geothermal Power Development. Geothermal Energy Association for the U.S. Department of Energy, Washington, D.C. http://www.geoenergy.org/publications/reports/Factors\%20Affecting\%20Cost\%20of\%20Geothermal\%20Power \%20Development\%20-\%20August\%202005.pdf.

INL - Idaho National Laboratory, 2005. Temperature at Depth Maps for the Continental United States. Accessed on August 13, 2010. http://geothermal.id.doe.gov/maps/.

ITSI - Innovative Technical Solutions. 2003. Geothermal Energy Resource Assessment on Military Lands. Innovative Technical Solutions, Inc. for the Department of Defense, NAWS

China Lake, Walnut Creek, California. http://www.geothermal.org/GEO_0001.PDF.

Shibaki, Masashi. 2003. Geothermal Energy for Electric Power. A Renewable Energy Policy Project (REPP) Issue Brief, Renewable Energy Policy Project, Washington, D.C. http://www.crest.org/articles/static/1/binaries/Geothermal_Issue_Brief.pdf.

SMU - Southern Methodist University. 2010. SMU Geothermal Databases. SMU Geothermal Laboratory, Dallas, Texas. Accessed January 2010 at http://smu.edu/geothermal/georesou/usa.htm. 


\section{APPENDIX D}

Analysis of Ground Source Heat Pump Opportunities 
Renewable Energy Opportunities at Fort Campbell, Tennessee/Kentucky Pacific Northwest National Laboratory, March 2011 


\section{Appendix D: Analysis of Ground Source Heat Pump Opportunities}

\section{Ground Source Heat Pump Technology}

Ground source heat pumps (GSHPs) use the stable temperatures of the earth and groundwater to improve the coefficient of performance of heating and cooling applications for buildings. Common GSHP configurations include open-loop, horizontal closed-loop, and vertical closedloop.

- $\quad$ Open-loop systems use open wells or bodies of water as direct heat transfer mediums to provide cool temperatures in the summer and warm temperatures in the winter. Heat transfer is only needed once, at the building, because groundwater is used directly, and the limited drilling and trenching results in a lower first cost.

- Closed-loop systems use heat transfer fluid inside a sealed pipe to exchange heat with the earth. Closed-loop systems have lower pumping requirements and are more efficient than open-loop systems. However, soil type and moisture content is more critical to the performance of these systems, and the trenching and drilling significantly increases first cost.

- In horizontal loops, all the piping lies at the same depth in the ground. The piping is laid in shallow trenches, and heat transfer takes place across the pipe wall between the fluid and the subsurface soil.

- Vertical closed-loop GSHPs operate using the same mechanism as horizontal ground loops, except that the piping is deployed in vertical boreholes. This is the most efficient configuration because of the more consistent soil temperatures at the depth reached by most boreholes.

GSHPs are applicable in almost any building with both heating and cooling. They can be used in buildings as small as 100 square feet, or up to 1 million square feet. Multiple GSHPs can be used in a single building or the same ground loop can be shared between buildings.

To install GSHPs at a building, the surrounding area will have certain prerequisites, depending on the type of GSHP. Open-loop GSHPs need a water source and sink. The source can be a well or open body of water. After the energy transfer has occurred, the water can be rejected to a secondary well, the open body of water used as the source, another body of water, or a storm drain. Water volume requirements depend on the size of GSHP installed, but typically between 1.5 and 3.0 gallons per minute are needed per cooling ton. This high water use greatly affects the feasibility of open-loop systems in some areas, as do local codes and regulations. Many locales do not want to risk groundwater depletion or contamination.

Horizontal closed-loop GSHPs have a different limiting factor: sufficient land area. The heat transfer for these systems occurs in pipes laid in trenches that are between 100 and 400 feet long per cooling ton, spaced between 6 and 12 feet apart and about 6 feet deep. The soil characteristics and number of pipes per trench determine the pipe length; more pipes (up to six) per trench save land space but require more piping per ton of cooling capacity. The trenching costs make horizontal ground loops more expensive to install than open loop systems, but if water availability is the only limiting factor, these systems tend to be the most economic.

D-1 Renewable Energy Opportunities at Fort Campbell, Tennessee/Kentucky Pacific Northwest National Laboratory, March 2011 
Where significant land area and water volume is not available, vertical closed-loop GSHPs may be the only option. In these systems, the heat transfer pipes are placed vertically in the ground, at depths of between 75 and 300 feet. Some land area is still required, because the pipe wells need to be spaced at least 15 to 20 feet apart, and 200 to 600 feet of piping are needed per cooling ton. Vertical ground loop systems tend to have the highest first cost of all the GSHP systems because of the cost of drilling multiple boreholes.

The tradeoff between land use, water use, and first cost generally determine which GHSP is appropriate for a particular building. All of these factors need to be taken into account when planning to deploy a GSHP system.

\section{Ground Source Heat Pump Analysis Approach}

For the purposes of this assessment, GSHPs were evaluated using the data from the 2009 Facility Energy Decision System (FEDS) assessment for Fort Campbell. Preliminary analyses of openloop, horizontal closed-loop, and vertical closed-loop configurations were performed for all buildings included in the FEDS assessment.

FEDS was previously used by Emily Rauch of PNNL in 2007 to assess GSHP opportunities for ECIP funding at Fort Campbell. While that analysis focused on specific buildings where GSHP could be implemented, this analysis takes a broad view of all buildings sets on-site and identifies any potential cost-effective retrofits for open-loop, closed-loop horizontal, and closed-loop vertical GSHPs.

The FEDS building energy model (see Appendix A) was used to develop a representation of Fort Campbell based upon a PNNL data-gathering trip in 2009. All existing buildings at that time were included in the model, and this renewables analysis used the model to assess current costeffective potential for GSHP retrofits in each of those buildings. Buildings built since 2009 were not added to the model, because buildings that new are typically not cost-effective to retrofit, and the types and sizes of the new buildings are still represented. Based on these results, site judgment can be used to determine cost-effectiveness of retrofitting the newer buildings in the future.

Building data was entered for groups of similar buildings based on age, size, and use type (see Table D-1). Table D-2 shows the actual buildings in each building group. For brevity, only buildings with cost-effective GSHP projects are shown in Table D-2. The FEDS model was updated with current fuel, equipment, labor prices, and fuel use information. 
Table D-1: Building Groups Analyzed in FEDS for GSHPs

\begin{tabular}{|c|c|c|c|c|c|}
\hline \multirow[b]{2}{*}{ Group ID } & \multicolumn{4}{|c|}{ Building Group Description } & \multirow[b]{2}{*}{$\begin{array}{l}\text { Example } \\
\text { Building }\end{array}$} \\
\hline & Use Type & $\begin{array}{l}\text { Average } \\
\text { Size } \\
\text { (sf) }\end{array}$ & $\begin{array}{l}\text { Average } \\
\text { Vintage }\end{array}$ & $\begin{array}{l}\text { Number of } \\
\text { Buildings } \\
\text { Represented }\end{array}$ & \\
\hline $10 a$ & Access Control Facility & 316 & 1997 & 72 & 5211 \\
\hline $10 \mathrm{~b}$ & 1940s Admin (WWII) & 5,467 & 1942 & 70 & 2176 \\
\hline $10 \mathrm{~d}$ & Small Old Admin & 4,624 & 1958 & 63 & 6925 \\
\hline $10 \mathrm{e}$ & Converted Hammerheads & 36,509 & 1956 & 8 & 3214 \\
\hline $10 f$ & Mid-Sized Old Admin & 7,470 & 1979 & 56 & 6302 \\
\hline $10 \mathrm{~g}$ & Older Office with Warehouse & 29,050 & 1980 & 7 & 3672 \\
\hline $10 \mathrm{~h}$ & Small New Admin & 4,184 & 2002 & 57 & 9138 \\
\hline $10 \mathrm{i}$ & Mid-Sized New Admin & 13,423 & 2001 & 29 & 7077 \\
\hline $10 \mathrm{j}$ & New Office with Warehouse & 28,067 & 2001 & 20 & 7086 \\
\hline $10 \mathrm{k}$ & Large New Admin & 66,827 & 2004 & 8 & 7075 \\
\hline $23 a$ & $\begin{array}{l}\text { Communications and } \\
\text { Electronics }\end{array}$ & 3,045 & 1958 & 31 & 7202 \\
\hline $23 b$ & Flight Simulator Buildings & 10,131 & 1986 & 27 & 6551 \\
\hline $30 a$ & Small Old Barracks & 7,489 & 1949 & 17 & 2996 \\
\hline $30 d$ & Hammerhead barracks & 37,632 & 1954 & 36 & 6938 \\
\hline $30 e$ & Guest Housing & 3,177 & 1982 & 18 & 1583 \\
\hline $30 f$ & Old Mid-Sized Barracks & 30,770 & 1977 & 12 & 4039 \\
\hline $30 \mathrm{~g}$ & Old Large Barracks & 40,559 & 1979 & 7 & 3766 \\
\hline $30 \mathrm{~h}$ & New Mid-Sized Barracks & 48,024 & 2007 & 9 & 6773 \\
\hline $30 \mathrm{j}$ & New Large Barracks & 95,101 & 2000 & 8 & 6763 \\
\hline $30 \mathrm{k}$ & New Very Large Barracks & 132,834 & 2004 & 4 & 7038 \\
\hline $40 \mathrm{~b}$ & Old Storage/warehouse & 5,883 & 1957 & 42 & 6460 \\
\hline $40 c$ & Large Old warehouse & 98,954 & 1956 & 3 & 5207 \\
\hline $40 d$ & Small storage & 3,517 & 1996 & 113 & 5510 \\
\hline $40 \mathrm{e}$ & Large Storage/warehouse & 16,150 & 1997 & 16 & 6488 \\
\hline $50 a$ & Old Hangar & 30,381 & 1971 & 13 & 7210 \\
\hline 50a_renov & Renovated Hangars & 43,660 & 1974 & 2 & 7214 \\
\hline $50 \mathrm{~b}$ & Hangar & 35,501 & 1992 & 15 & 7243 \\
\hline $50 \mathrm{c}$ & Vehicle Maintenance & 3,108 & 1964 & 117 & 7047 \\
\hline $50 d$ & Old Shops & 16,862 & 1958 & 17 & 7085 \\
\hline $50 e$ & New Small Shops & 6,581 & 2000 & 53 & 6833 \\
\hline $50 f$ & New Large Shops & 37,913 & 1996 & 7 & 6871 \\
\hline $60 d$ & Dining & 13,469 & 1996 & 14 & 7048 \\
\hline $60 \mathrm{e}$ & Fire Station & 7,869 & 1976 & 9 & 4099 \\
\hline $80 a$ & Showers/toilets & 1,613 & 1978 & 18 & 6142 \\
\hline $80 \mathrm{c}$ & Fitness Center & 11,678 & 1979 & 20 & 3932 \\
\hline
\end{tabular}

D-3 
Table D-2: Buildings Analyzed in FEDS for GSHPs*

\begin{tabular}{|c|c|c|}
\hline Description & Group ID & Building Numbers \\
\hline $\begin{array}{l}\text { Older Office with } \\
\text { Warehouse }\end{array}$ & $\begin{array}{l}\log \text { (only office } \\
\text { section) }\end{array}$ & $5661,3672,2601,6225$ \\
\hline $\begin{array}{l}\text { Communications and } \\
\text { Electronics }\end{array}$ & $23 a$ & $\begin{array}{l}\text { 6839, } 9017,9018,6241,7541,832,826,828,1 \mathrm{RN} 46 \\
\text { NRAD2, } 7549,9022,7187,7202,7212, \text { A7180, A7163, } \\
\text { A6628, A7297, 7297, 7180, A7230, A7201, 7230, 7293, } \\
7168,7108,7164,7292, \mathrm{D} 7277,95\end{array}$ \\
\hline New Mid-Sized Barracks & $30 h$ & 6772, 2989, 2990, 6771, 6773, 6753, 6754, 2992, 2993 \\
\hline Fitness Center & $80 \mathrm{c}$ & $\begin{array}{l}7540,6992,6990,3610,7246,7037,2270,2191,2570, \\
2193,6143,7546,6657,6145, E 6621,6645,6646,80,6146\end{array}$ \\
\hline
\end{tabular}

* Building groups with no economically feasible projects are not included in this list.

Site-specific TMY (typical meteorological year) weather data and soil/ground characteristics were also used in the analysis. The weather data used for this analysis came from Fort Campbell. Soil testing and groundwater evaluation is necessary before actual costs can be determined. This analysis uses the following assumptions (based on the site's geographic location) for the local soil conditions. These values are consistent with the assumptions used in previous analysis by PNNL and FEMP.

- Soil thermal diffusivity: $0.0483 \mathrm{ft}^{2} / \mathrm{hr}$

- Soil type: heavy soil- damp

- Bedrock thermal conductivity: $1.68 \mathrm{Btu} / \mathrm{hr} \cdot \mathrm{ft} \cdot{ }^{\circ} \mathrm{F}$

The model does not consider site limitations like land area or water source availability. The assumption is that there are sufficient thermal sources/sinks in place. Soil and water characteristics can change across the same site, so the data used for this assessment is, while representative, not precise enough to use in the design of a specific system.

\section{Ground Source Heat Pump Resource Characterization}

GSHP assessments using FEDS have been completed at many sites in the past using the same analytic approach. The results developed here agree with previous findings. In general, conditions favoring replacement of existing heating and cooling systems with GSHPs include:

- Replacing old equipment. Equipment at the end of its useful life that will soon be replaced provides further economic incentive for GSHP installations, particularly if existing ductwork can be reused.

- More extreme climates. Cold winters, hot summers, or large daily temperature swings allow GSHPs to operate more efficiently than other electric cooling and heating systems. The cost of heating operation is comparable to non-electric heating systems.

- High cost of non-electric fuels. If electricity is less than approximately 3.5 times as expensive per Btu than other fuels, GSHPs will generally be cost-effective. If no other 
fuel option is available and electric costs are high, GSHPs will be less expensive to operate than air-source heat pumps.

GSHPs are often not cost-effective in a building that:

- Does not have both cooling and heating. A building needs to be both heated and cooled to take advantage of the GSHP efficiency in both modes. However, most of the savings are realized in the heating mode, so buildings with no cooling can still benefit from GSHPs.

- Does not currently have ductwork. Installing a new air distribution system in addition to the conditioning equipment generally adds too much cost for a GSHP retrofit, unless the building is modified to allow zone-level heat pumps to be used in conjunction with a water loop, connecting the terminal units to a shared ground loop.

- Is newer. Newer buildings (less than about 4 years old) generally have fairly efficient equipment (or at least the performance has not yet degraded significantly). As a result, premature replacement with a GSHP is generally uneconomic. In addition, the building envelope tends to be better, lengthening payback duration.

- Is located in a mild climate. Buildings in mild climates do not have the temperature extremes that make the ground loop important. A standard air-source heat pump would probably suffice.

- Uses an air-source heat pump. An air-source heat pump has many of the benefits of a GSHP except in extreme temperature conditions. These extreme temperature conditions often are not enough to justify replacement.

- Is connected to a central energy plant (unless the CEP will be abandoned). Although we often consider central energy systems as big energy wasters, on a building-by-building basis (which does not account for distribution losses) it is difficult to justify replacement. Centralized chiller plants can use larger, more efficient water-cooled units and can stage several chillers to run closer to full load (most efficient mode).

\section{Ground Source Heat Pumps: Economic and Other Analysis Parameters}

FEDS allows two primary financing options: appropriated funding (using energy conservation investment program, or ECIP, funds) and alternative financing (utility energy services contract, or UESC, or energy saving performance contract, or ESPC). The parameters for alternative financing can be adjusted to match the options available to the site. For this assessment, a project life of 25 years and a third-party interest rate of $5 \%$ were used.

FEDS uses the site electric rate schedule and energy costs to determine fuel costs and savings for GSHP retrofits. The entire rate schedule is used so that consumption and demand can be calculated on a time-of-use basis. Fossil fuel prices were determined using FY 2009 Army Energy and Water Reporting System (AEWRS) data. The following energy costs were used for the analysis.

- Electricity: 4.14ø/kWh (\$12.13/MMBtu)

D-5 Renewable Energy Opportunities at Fort Campbell, Tennessee/Kentucky Pacific Northwest National Laboratory, March 2011 
- Natural Gas: \$7.57/MMBtu

The electric rate structure includes both standard demand charges and demand ratchets. The effective demand charge was determined to be $\$ 16.77 / \mathrm{kW}$. The average installed cost per unit of cooling capacity in buildings that were found to be cost-effective is as follows:

Open loop: $\$ 2,077$ per ton

Horizontal closed-loop: $\$ 2,605$ per ton

The difference in costs reflects economies of scale working in favor of larger projects. Where fewer or smaller units are being installed, the price increases comparatively with a similar technology. Open-loop systems tend to have the lowest installed cost, especially for larger building. Costs are only shown for technologies that were found to be cost-effective in this analysis.

\section{Findings: Ground Source Heat Pumps}

GSHPs were only found to be economic in a few situations at Fort Campbell. GSHPs work well in buildings with relatively balanced heating and cooling loads because the installed capacity can be fully utilized in both the summer and winter. Although Fort Campbell has more heatingdegree-days than cooling-degree-days, some buildings at Fort Campbell have relatively balanced heating and cooling loads because of internal heat gains that require year-round cooling. In addition, Fort Campbell has low electricity rates, but high demand charges. The high demand charges along with relatively low natural gas prices make it more challenging to find feasible projects. Despite these challenges, preliminary analysis shows that some open-loop and horizontal closed-loop GSHP retrofits are cost-effective. No cost-effective projects with vertical close-loop GSHPs were identified.

The simple payback values presented in Table D-3 are the average for all buildings with economic projects within that group. Some of the building groups in Table D-3 contain buildings served by different fuels or with other noteworthy differences. Table D-4 provides the specific heating and cooling technologies and additional economic results for each building group examined.

Table D-3: Simple Payback Period for Building Groups Analyzed in FEDS for GSHPs*

\begin{tabular}{|c|c|c|c|}
\hline \multirow{2}{*}{ Description } & \multirow{2}{*}{ Group ID } & \multicolumn{2}{|c|}{ Appropriated Financing } \\
\hline & & Open ${ }^{\star *}$ & Horizontal $\dagger$ \\
\hline Older Office with Warehouse & $\log$ (Office section) & 10.4 & - \\
\hline Communications and Electronics & $23 a$ & - & 13.4 \\
\hline New Mid-Sized Barracks & $30 \mathrm{~h}$ & 11.5 & 13.2 \\
\hline Fitness Center & $80 c$ & 13.1 & - \\
\hline
\end{tabular}

* Building groups with no economically feasible projects are not included in this list

** Open-loop GSHP

$\dagger$ Horizontal closed-loop GSHP 
Table D-4: Simple Payback Period for Building Groups Analyzed in FEDS for GSHPs*

\begin{tabular}{|c|c|c|c|c|c|c|c|}
\hline $\begin{array}{l}\text { Funding } \\
\text { Source }\end{array}$ & Description & Group ID & $\begin{array}{c}\text { Current } \\
\text { Heating/Cooling } \\
\text { Technology }\end{array}$ & $\begin{array}{c}\text { Retrofit } \\
\text { Technology }\end{array}$ & $\begin{array}{l}\text { Payback } \\
\text { Period } \\
\text { (years) }\end{array}$ & $\begin{array}{l}\text { Savings to } \\
\text { Investment } \\
\text { Ratio }\end{array}$ & $\begin{array}{l}\text { Installed } \\
\text { Capital } \\
\text { Cost }\end{array}$ \\
\hline ECIP & $\begin{array}{c}\text { Older Office } \\
\text { with Warehouse }\end{array}$ & $\begin{array}{c}10 \mathrm{~g} \text { (only } \\
\text { office section) }\end{array}$ & $\begin{array}{c}\text { Natural Gas } \\
\text { Conventional Boiler / } \\
\text { Electric Air-Cooled } \\
\text { Chiller } \\
\end{array}$ & $\begin{array}{l}\text { Open-Loop } \\
\text { GSHP }\end{array}$ & 10.4 & 1.5 & $\$ 886,596$ \\
\hline ECIP & $\begin{array}{l}\text { Communications } \\
\text { and Electronics }\end{array}$ & $23 a$ & $\begin{array}{l}\text { Electric Conventional } \\
\text { Furnace / Electric } \\
\text { Package Unit }\end{array}$ & $\begin{array}{l}\text { Horizontal } \\
\text { Closed- } \\
\text { Loop GSHP }\end{array}$ & 13.4 & 1.0 & $\$ 1,122,185$ \\
\hline ECIP & $\begin{array}{c}\text { New Mid-Sized } \\
\text { Barracks }\end{array}$ & $30 \mathrm{~h}$ & $\begin{array}{c}\text { Natural Gas } \\
\text { Conventional Boiler / } \\
\text { Electric Air-Cooled } \\
\text { Chiller } \\
\end{array}$ & $\begin{array}{l}\text { Horizontal } \\
\text { Closed- } \\
\text { Loop GSHP }\end{array}$ & 13.2 & 1.2 & $\$ 1,254,843$ \\
\hline ECIP & $\begin{array}{c}\text { New Mid-Sized } \\
\text { Barracks }\end{array}$ & $30 \mathrm{~h}$ & $\begin{array}{c}\text { Natural Gas } \\
\text { Conventional Boiler / } \\
\text { Electric Air-Cooled } \\
\text { Chiller }\end{array}$ & $\begin{array}{l}\text { Open-Loop } \\
\text { GSHP }\end{array}$ & 11.5 & 1.2 & $\$ 1,072,804$ \\
\hline ECIP & Fitness Center & $80 \mathrm{c}$ & $\begin{array}{c}\text { Natural Gas } \\
\text { Conventional Boiler / } \\
\text { Electric Air-Cooled } \\
\text { Chiller } \\
\end{array}$ & $\begin{array}{l}\text { Open-Loop } \\
\text { GSHP }\end{array}$ & 13.1 & 1.1 & $\$ 2,070,111$ \\
\hline
\end{tabular}

No projects with alternative financing (e.g., a UESC) were found to be cost-effective. With UESCs and ESPCs, the project is financed, which adds to the capital costs. In addition, both the site and the financier must benefit from the maintenance and energy savings. As a result, the economics of GSHPs with alternative financing are generally worse than projects with appropriated financing.

All of the cost-effective GSHP projects are currently served by either natural gas or, in the case of building set 23a, electric resistance heat. No cost-effective retrofits were identified for buildings served by CEPs.

To a large extent, this analysis affirms PNNL's 2007 findings for potential ECIP projects; that there are limited opportunities for GSHP retrofit projects a Fort Campbell. Buildings 5661 and 6990, which were identified as potential projects for ECIP funding by PNNL in 2007, were again found to be cost-effective, though only for open-loop systems. Since 2007, electric prices have increased. Although a higher electric rate increases summer savings, it also increases the cost of heating with GSHPs. Also, the price of natural gas at Fort Campbell has actually decreased since 2007, which reduces the savings associated with GSHPs. Nevertheless, the analysis concluded that there are still a limited number of buildings where GSHP retrofits are cost-effective.

In addition to pursuing retrofit opportunities, Fort Campbell should consider GSHPs for new construction. The analysis undertaken to assess the potential for GSHPs on Fort Campbell applies only to installing systems in existing buildings. For new buildings, project economics tend to be considerably better because of the ability to optimize a building's design with a GSHP in mind. Also, the remaining value of any heating or cooling systems that are to be replaced does not have to be accounted for when determining the economics of a project in a new building. The total potential energy savings for Fort Campbell is difficult to determine because 
the savings depend on which type of GSHP is implemented. However, if all cost-effective GSHP retrofit projects were implemented and there were no land or water use restrictions, the annual energy savings would be about approximately 32,000 MMBtu or about 2\% of total building energy use.

\section{Ground Source Heat Pumps: Next steps}

Fort Campbell should determine which buildings to investigate in detail. Some of the buildings identified have already been investigated for ECIP funding. For buildings that were not analyzed in detail, such as the communications and electronics buildings (23a) or the new mid-sized barracks (30h), Fort Campbell should determine whether conditions are appropriate for GSHP systems (space for wells, etc.). Also, consider whether groundwater conditions and local regulations allow for open-loop systems for the buildings identified above. Again, open-loop systems require access to an adequately sized well or body of water and a means of rejecting water (injection well, open body of water, river, or storm drain) after heat exchange has occurred. Depending on the needs of the funding source (i.e., ECIP projects should be at least $\$ 750,000$ in capital cost), Fort Campbell may need to group multiple GSHP projects or combine GSHPs with other renewable energy or energy efficiency projects.

Once buildings are determined to be cost-effective and have appropriate access to sources and sinks, these buildings can then be put into a project proposal, and experienced designers in the area can be contacted to develop detailed project designs.

Lastly, for new construction, conduct soil tests during site excavations. Work with designers to incorporate GSHPs early in the process. Choose a method of funding as necessary and make sure it is available.

\section{Ground Source Heat Pump Sources of Information}

FEMP - Federal Energy Management Program. 2001. Federal Technology Alert: Ground Source Heat Pumps Applied to Federal Facilities - Second Edition. DOE/EE-0245, Federal Energy Management Program, U.S. Department of Energy, Washington, DC. Accessed May 2010 at http://www1.eere.energy.gov/femp/pdfs/FTA_gshp.pdf.

Goetzler W, R Zogg, H Lisle, and J Burgos. 2009. Ground Source Heat Pumps: Overview of Market Status, Barriers to Adoption, and Options for Overcoming Barriers. Prepared by Navigant Consulting, Inc. for the U.S. Department of Energy, Energy Efficiency and Renewable Energy Geothermal Technologies Program, Washington, DC. Accessed May 2010 at http://www1.eere.energy.gov/geothermal/pdfs/gshp_overview.pdf.

Hughes P. 2008. Geothermal (Ground-Source) Heat Pumps: Market Status, Barriers to Adoption, and Actions to Overcome Barriers. ORNL/TM-2008/232, Energy and Transportation Science Division, Oak Ridge National Laboratory, Oak Ridge, TN. Accessed May 2010 at http://www1.eere.energy.gov/geothermal/pdfs/ornl_ghp_study.pdf. 


\section{APPENDIX E}

Analysis of Solar Opportunities 
Renewable Energy Opportunities at Fort Campbell, Tennessee/Kentucky Pacific Northwest National Laboratory, March 2011 


\section{Appendix E: Analysis of Solar Opportunities}

\section{Solar Technology}

There is a wide range of solar technologies and applications available for energy generation. Solar technologies can be classified by the specific technique used for converting solar energy into useful energy. Solar energy is unique in that the sun's energy, or insolation, can be captured to provide electrical energy, heating energy (solar thermal), or a combination of both.

Solar technologies can be further categorized by their scale. Large-scale solar projects can easily exceed $1 \mathrm{MW}$ and can have hundreds of collectors. Smaller-scale projects, often at the building level, are also possible and may be more desirable because of land area limitations, aesthetics considerations, or for energy security. Certain solar technologies, such as photovoltaic (PV), can be either large-scale or small-scale, while technologies such as solar hot water heating are only found at the building level.

\section{Solar Electric}

Solar electric collectors are either PV arrays or concentrating solar arrays. There are three major $\mathrm{PV}$ array subcategories, as follows:

- Flat Panel. Arrays of PV modules mounted on racks either at ground level or on rooftops at a fixed angle. Generally, this angle is equal to the location's latitude. On rooftops, the angle can be the angle of the rooftop or an angle set by specialized mounting brackets attached to the roof. In addition, there are two common PV technologies on the market, silicon PV and cadmium telluride (CdTe) "thin film" PV. Other PV technologies such as gallium arsenide (GaAs) and copper-indium selenide (CIGS) are available, but uncommon.

- Axis-Tracking. PV arrays can be mounted on an assembly that moves throughout the day to keep the array positioned at an optimum angle to maximize the captured sunlight (Figure E-1). An axis-tracking system can be either single- or dual-axis in nature. A single-axis tracking system typically has a fixed tilt and the system follows the sun's trajectory across the sky. These systems are able to collect more sunlight than nontracking systems. A dual-axis tracking system allows the panels to rotate along two axes, thereby truly maximizing the panel's ability to harvest solar energy. However, these systems are considerably more complex and impose additional operations and maintenance $(\mathrm{O} \& \mathrm{M})$ costs than flat panel assemblies. 


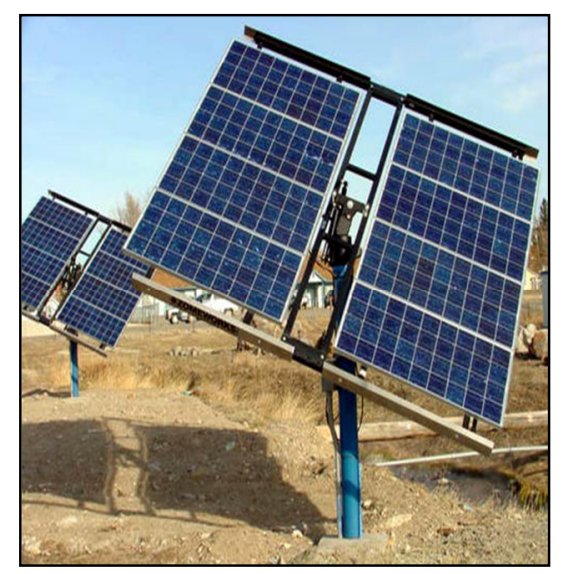

Figure E-1: Axis-Tracking PV Array

Concentrating solar power (CSP) systems use mirrors, lenses, and other optical devices to concentrate the sun's energy. There are four primary configurations of thermal CSP systems:

- Solar Dish. A solar dish system employs an engine that is able to harvest thermal energy to generate electricity. These dual-axis tracking systems use dish-like concentrators to focus thermal energy on a point where a heat engine is mounted. Stirling engines are frequently used in solar dish applications. Most systems are several kilowatts to tens of kilowatts in size.

- Solar Power Tower. A solar power tower system uses very large arrays of mirrors, or heliostats, to concentrate the sun's energy on a central receiver tower to produce steam that drives a generator. Thermal storage allows the system to store thermal energy for use at dusk and into the evening. Most existing or planned commercial solar power tower plants are larger than $10 \mathrm{MW}$.

- Solar Trough. When used for power generation, these large arrays concentrate the sun's energy onto a pipe containing a liquid that is used to generate steam that drives a generator. These systems always employ single-axis tracking mirrors or reflectors orientated along the north-south axis and are highly sensitive to the slope of the ground because of the need to pump the liquid through the collector tubes. Cogeneration and thermal storage are options for this technology as well. Solar trough plants are $40 \mathrm{MW}$ or larger.

- Concentrating PV. In a CPV system, mirrors and/or lenses focus sunlight onto a small area of PV material. Typically, this PV material is more sophisticated and expensive than the PV material used in conventional solar cells. However, these advanced PV cells are also more efficient and are capable of absorbing insolation levels equivalent to dozens to hundreds of suns. While there are several commercial, small-scale CPV arrays and a handful of medium-scale utility demonstration projects, this technology is still too immature to be considered in this analysis.

Thermal CSP plants are still in various stages of development. While thermal CSP plants are somewhat unproven compared to traditional PV plants, they have the potential to deliver large quantities of energy at competitive prices. 
Thermal concentrating power systems were not considered for this assessment because the available direct normal insolation is less than the $6.75 \mathrm{kWh} / \mathrm{m}^{2} /$ day threshold typically cited for CSP feasibility (DOE 2010). Direct normal insolation is a subset of the total insolation levels that excludes the indirect (diffuse) insolation, which is reflected from clouds or the ground, because this insolation cannot be concentrated. Fort Campbell has an average direct normal insolation level of $4.38 \mathrm{kWh} / \mathrm{m}^{2} /$ day (NASA 2010), which is below the $6.75 \mathrm{kWh} / \mathrm{m}^{2} /$ day target.

\section{Solar Thermal}

Rather than electricity as the end product, solar energy can also be used to directly heat air in the form of transpired solar collectors (i.e., solar walls), water that is used for space heating, or water that is used for service hot water (SHW) or swimming pools. These solar energy systems can be cost-competitive even when PV is not. However, solar thermal projects do not count towards the EPAct mandate and therefore are excluded from this analysis.

\section{Solar Analysis Approach}

The analytic approach for the solar energy assessment consists of the following steps:

$\checkmark$ Identify solar potential-Use established sources to determine seasonal and annual solar radiation for the site.

$\checkmark$ Determine utility perspective-Obtain electric rate tariff information, evaluate state and local regulations, and identify grants, incentives, and other support.

$\checkmark \quad$ Identify potential development areas - Study existing electrical transmission system and identify installation-specific sites and potential users of generated energy.

$\checkmark$ Determine applicable solar technology - Evaluate solar electric technologies including both large-scale (approximately 1+ MW) applications, such as a ground-mounted PV array, and small-scale (kW-scale) applications, such as roof-mounted PV systems.

$\checkmark$ Develop project economics-Determine project capital investment requirements, project O\&M costs, and estimate economic value of expected electric production based on selected solar technology and market prices.

\section{Solar Resource Characterization}

The central region of the United States experiences insolation levels ranging from 3.5 to 5.5 $\mathrm{kWh} / \mathrm{m}^{2} /$ day. From a resource perspective, Fort Campbell is positioned in a region of moderate solar potential. Figure E-2 displays the annual mean horizontal insolation on a south facing, latitude-tilted collector for the region. 


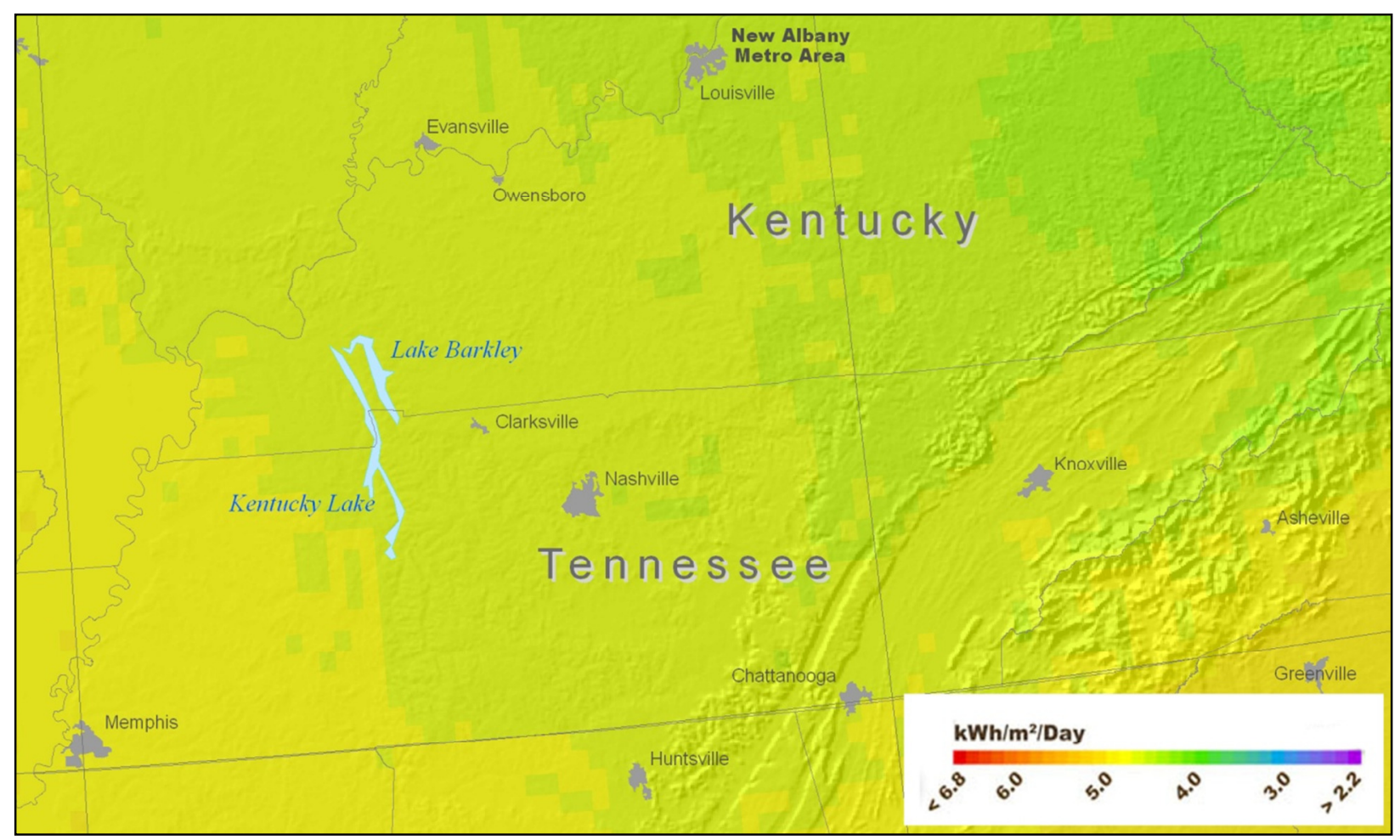

Figure E-2: Solar Insolation Levels (NREL 2008)

The solar resource potential was estimated using the solar potential estimates in National Aeronautics and Space Administration's (NASA) Surface meteorology and Solar Energy (SSE) data and Natural Resources Canada's RETScreen analysis software. The SSE data set is a continuous and consistent 10-year global climatology of insolation and meteorology data on a $1^{\circ}$ by $1^{\circ}$ grid system. Although the SSE data within a particular grid cell are not necessarily representative of a particular microclimate within the cell, the data are considered to be the average over the entire area of the cell. That estimate should be sufficiently accurate for preliminary feasibility studies of new renewable energy projects.

Table E-1 shows the average solar insolation data for several different surface orientations. Average monthly insolation values are provided in $\mathrm{kWh} / \mathrm{m}^{2} /$ day for the following conditions:

- Tilt 0 - Collector installed at a $0^{\circ}$ tilt (i.e., on a flat surface such as a roof).

- Tilt (lat-15) - A tilt of latitude minus $15^{\circ}$ would favor energy production in the summer when the sun is higher.

- Tilt lat - Tilting a PV array at an angle equal to the latitude is a generally accepted way to optimize annual electricity production.

- Tilt (lat+15) - A tilt of latitude plus $15^{\circ}$ would favor energy production in the winter when the sun is lower.

- Tilt 90 - Collector installed against a vertical surface (i.e., a wall).

- Single-Axis Tracking - A collector capable of tracking the sun's azimuth angle over the course of the day. 
Table E-1: Monthly Averaged Insolation Incident on a South-Facing Tilted Surface at Fort Campbell $\left(\mathrm{kWh} / \mathrm{m}^{2} / \mathrm{day}\right)$

\begin{tabular}{|l|c|c|c|c|c|c|c|c|c|c|c|c|c|}
\hline & Jan & Feb & Mar & Apr & May & Jun & Jul & Aug & Sep & Oct & Nov & Dec & $\begin{array}{c}\text { Annual } \\
\text { Average }\end{array}$ \\
\hline Tilt 0 & 2.3 & 3.1 & 4.1 & 5.4 & 6.0 & 6.5 & 6.3 & 5.7 & 4.7 & 3.8 & 2.5 & 2.0 & 4.4 \\
\hline Tilt 22 & 3.2 & 3.9 & 4.6 & 5.6 & 5.9 & 6.2 & 6.1 & 5.8 & 5.1 & 4.6 & 3.3 & 2.8 & 4.8 \\
\hline Tilt 37 & 3.5 & 4.2 & 4.7 & 5.5 & 5.6 & 5.7 & 5.6 & 5.6 & 5.2 & 4.9 & 3.7 & 3.2 & 4.8 \\
\hline Tilt 52 & 3.7 & 4.2 & 4.6 & 5.0 & 4.9 & 4.9 & 4.9 & 5.0 & 4.9 & 4.9 & 3.8 & 3.4 & 4.5 \\
\hline $\begin{array}{l}\text { Single } \\
\text { Axis } \\
\text { Tracking }\end{array}$ & 4.2 & 5.0 & 5.8 & 6.9 & 7.2 & 7.4 & 7.3 & 7.2 & 6.5 & 6.2 & 4.4 & 3.7 & 6.0 \\
\hline
\end{tabular}

As shown, a flat collector tilted at $37^{\circ}$ (the site's latitude) has an average yearly solar potential of $4.8 \mathrm{kWh}_{\text {solar }} / \mathrm{m}^{2} /$ day. A single-axis tracking PV array will receive $6.0 \mathrm{kWh}_{\text {solar }} / \mathrm{m}^{2} /$ day of incident solar radiation. Figure E-3 shows this incident solar radiation on a flat roof surface $\left(0^{\circ}\right.$ tilt $)$, a fixed array (latitude tilt), and a single-axis tracking array at Fort Campbell.

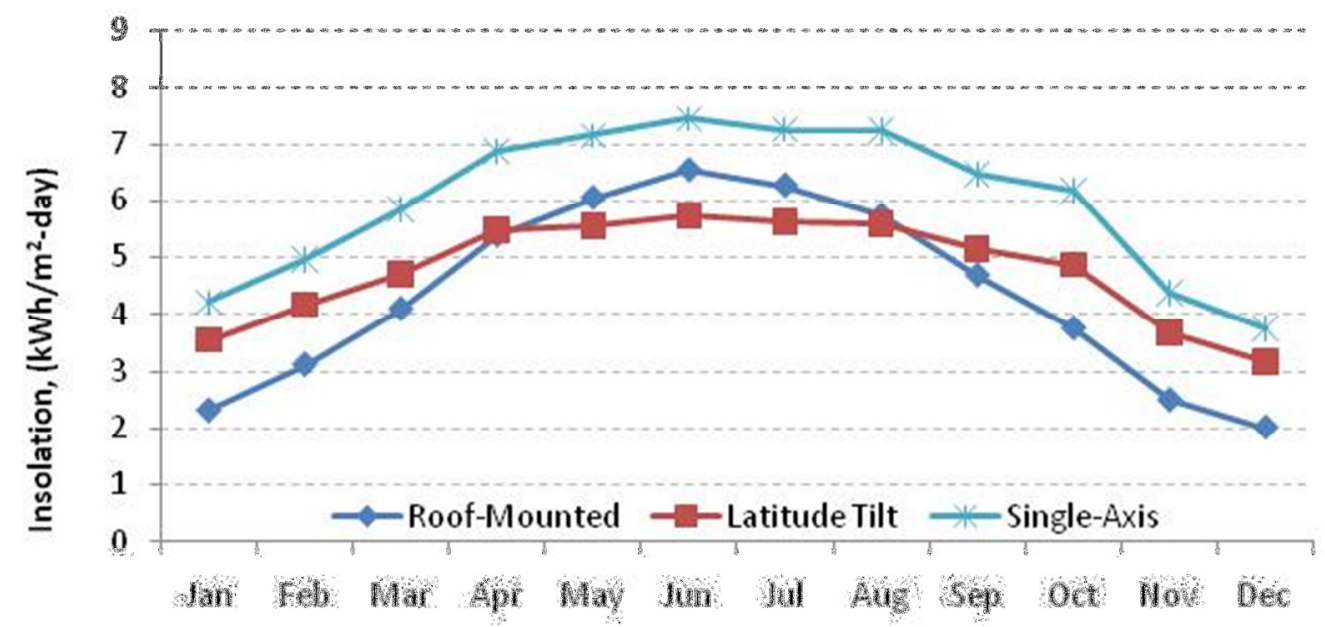

Figure E-3: Average Daily Insolation at Fort Campbell

\section{Siting Considerations for PV Technologies}

Compared to most renewable energy technologies, PV panels have a fair degree of siting flexibility. As previously mentioned, an array can be mounted on the ground or upon existing buildings and structures. A potential site needs to be free of any objects, such as trees or buildings, which may cast a shadow on the array. Also, the system will require an inverter to convert the DC output power into AC power. For projects $25 \mathrm{~kW}$ or larger, it is common to use multiple inverters to optimize the system's efficiency as well as provide redundancy.

A typical 1-kW PV array may range in size from 8 to $9 \mathrm{~m}^{2}$; however, a larger array requires access space as well as spacing between the rows of panels to avoid self-shading, and will subsequently require a greater amount of space per installed $\mathrm{kW}$. For example, a 30-kW array would likely require $550 \mathrm{~m}^{2}$, and a $100-\mathrm{kW}$ array may require nearly $2,000 \mathrm{~m}^{2}$, assuming that the PV array occupies 50\% of the space. Panels mounted on slanted roofs can usually be more tightly grouped because of a decrease in self-shading potential. In addition, large arrays can 
produce considerable amounts of energy and require siting near existing high voltage power lines.

Fort Campbell appears to have a moderate amount of open space for ground-mounted PV. Possible sites that appear to have sufficient open space and are relativity free from shading include:

- The empty field between A Shau Valley Road and Market Garden Road near State Line Road,

- The empty field south of Perimeter Road and $3^{\text {rd }}$ Street,

- The empty fields northeast and southeast of Market Garden Road and $18^{\text {th }}$ Street.

There are additional spaces spread throughout Fort Campbell that might be suitable for a PV array. The terrain is generally flat, but is frequently heavily wooded. The primary disadvantage of these areas is the increased expense of land preparation for a PV array. The availability of space near the cantonment area suggests that considering more remote areas for large-scale PV deployment may not be necessary

\section{Findings: Solar Electric Production}

Solar conversion is an inefficient process; typical PV cells have a conversion efficiency ranging from $10 \%$ to $20 \%$. Taking into account the annual solar potential and the efficiency of a typical PV system, each fixed-angle, latitude-tilted MW of installed PV would be expected to produce 1,498 $\mathrm{MWh}_{\text {electric }}$ at Fort Campbell. The system would have a capacity factor of $17.1 \%$.

A single-axis tracking PV array can produce significantly more electricity than a stationary PV array, resulting in a higher output per unit surface area, and has a much flatter energy output profile during the day. The tracking racks increase the cost of installation by approximately $\$ 1$ to $\$ 2$ per installed watt. A 1-MW single-axis tracking array would produce $1,874 \mathrm{MWh}_{\text {electric }}$ annually at Fort Campbell. The system would have a capacity factor of $21.4 \%$.

A building-mounted PV array installed on a flat roof at Fort Campbell would be expected to produce between 1,202 to 1,205 $\mathrm{MWh}_{\text {electric }}$ annually per $1 \mathrm{MW}$ of installed capacity depending on the PV technology. The system would have a capacity factor of 15.7 to $15.9 \%$, depending on the PV technology.

A summary of the solar electric production information can be found in Table E-2.

Table E-2: Solar Electric Production by System Type at Fort Campbell

\begin{tabular}{|c|c|c|c|c|c|}
\hline System Type & $\begin{array}{l}\text { Assumed PV } \\
\text { Module } \\
\text { Efficiency } \\
\end{array}$ & $\begin{array}{l}\text { Solar Insolation, } \\
\mathbf{k W h}_{\text {(solar) }} / \mathrm{m}^{2} / \mathbf{y r}\end{array}$ & $\begin{array}{c}\text { Electric } \\
\text { Production, } \text { MWh }_{\text {(electric) }} / \mathbf{y r}\end{array}$ & $\begin{array}{l}\text { Specific Yield, } \\
\mathrm{kWh} / \mathrm{m}^{2}\end{array}$ & $\begin{array}{l}\text { Capacity } \\
\text { Factor }\end{array}$ \\
\hline $\begin{array}{l}1 \text { MW South-Facing, } \\
\text { Latitude Tilt }\end{array}$ & $18.7 \%$ & 1,74 & 1,498 & 277 & $17.1 \%$ \\
\hline $\begin{array}{c}1 \text { MW Single-Axis } \\
\text { Tracking }\end{array}$ & $18.7 \%$ & 2,180 & 1,874 & 347 & $21.4 \%$ \\
\hline $\begin{array}{c}1 \text { MW Roof Mounted } \\
\text { Silicon PV }\end{array}$ & $18.7 \%$ & 1,600 & 1,374 & 254 & $15.7 \%$ \\
\hline $\begin{array}{l}1 \text { MW Roof Mounted } \\
\text { CdTe Thin Film PV }\end{array}$ & $11.0 \%$ & 1,600 & 1,396 & 168 & $15.9 \%$ \\
\hline
\end{tabular}




\section{Findings: Solar Project Economics}

Based on current average solar system costs and the projected performance for the various solar system configurations, life-cycle costs were developed for solar technologies at Fort Campbell under two funding scenarios:

- Appropriated, using Energy Conservation Investment Program (ECIP) funds, and

- Third-party financing via an independent power producer (IPP).

Cost-effective ECIP projects have savings-to-investment ratio (SIR) values greater than 1.0, while a $10 \%$ internal rate of return (IRR) shows whether the IPP scenario is cost-effective.

Third-party financing utilizes a third party to develop, fund, and own the projects under a power purchase agreement (PPA) or other vehicle. The third party, being a private company or utility, could take advantage of tax credits for renewable energy projects and may sell the renewable energy credits (RECs), which in turn lower the cost required to pay for the electricity. Buildingintegrated PV can also be developed by a third party to take advantage of government incentives.

Solar PV arrays are generally no larger than several megawatts, and are not capable of providing baseload power because of their intermittent nature. Therefore, PV arrays can typically only displace electricity charges and not power charges. This charge is known as the marginal electric rate. The marginal electric rate at Fort Campbell was calculated to be $4.14 \phi / \mathrm{kWh}$.

This analysis assumed that the state sales tax is $0 \%$ as PV systems are exempt from sales tax in Kentucky. Furthermore, the analysis also assumed a 1.2\% inflation rate, MACRS depreciation, a $6 \%$ state income tax, and a $1.38 \%$ property tax.

At this time, none of the systems considered is cost-competitive. The CdTe thin film array proved to be the most cost-effective, among the systems examined. The combination of the moderate solar resource, moderately low-cost energy, and high system capital costs is the principle barrier to economic solar power generation for all scenarios at Fort Campbell. The SIR and simple payback for the ECIP scenario, the cost of electricity at a 10\% IRR for the IPP scenario, and the assumed system costs are shown in Table E-3 for each technology.

Table E-3: Economic Results for Solar Technologies at Fort Campbell

\begin{tabular}{|l|c|c|c|c||}
\hline Solar PV System & $\begin{array}{c}\text { Ground-Mounted } \\
\text { Fixed-Tilt PV }\end{array}$ & $\begin{array}{c}\text { Ground-Mounted } \\
\text { Axis-Tracking PV }\end{array}$ & $\begin{array}{c}\text { Roof-Mounted } \\
\text { CdTe PV }\end{array}$ & $\begin{array}{c}\text { Roof-Mounted } \\
\text { Si PV }\end{array}$ \\
\hline $\begin{array}{l}\text { Equipment Cost Assumptions, } \\
\text { \$/kW }\end{array}$ & 5,625 & 6,625 & 4,000 & 4,500 \\
\hline SIR & 0.12 & 0.10 & 0.15 & 0.13 \\
\hline Simple Payback, yrs & 120 & 136 & 95 & 109 \\
\hline $\begin{array}{l}\text { Cost of Electricity at 10\% IRR, } \\
\text { /kWh }\end{array}$ & 32.7 & 30.9 & 23.6 & 27.8 \\
\hline Variable O\&M, $\mathbf{k} / \mathbf{k W h}$ & 0.0 & 0.0 & 0.0 & 0.0 \\
\hline Fixed O\&M, \$/net kW & 20 & 33 & 20 & 20 \\
\hline $\begin{array}{l}\text { Federal Energy Tax Credit (a } \\
\text { credit worth a percentage of } \\
\text { the expenditures) }\end{array}$ & $30 \%$ & $30 \%$ & $30 \%$ & $30 \%$ \\
\hline
\end{tabular}


During the site visit, the site expressed interest in PV as local experts have advised the site that PV might be economic. However, at the current market rate and using prescribed economic factors, no PV array was found to be economic. Without access to other economic analyses, it is difficult to comment on the difference of conclusions. However, the use of different, nonprescribed energy escalation rates, inflation rates, blended electricity rates, and others can strongly affect the economic results.

Given the economic performance of the PV system considered, PV projects will not be costeffective unless RECs can be sold. Based on the analysis of the systems considered, RECs would need to sell for approximately 20 to $28 \mathrm{c} / \mathrm{kWh}$ (after factoring in the fixed cost of electricity) to attract investors. Also, the site would need to conduct a REC swap, i.e., purchase low cost RECs on the wholesale market, if the site wished to claim renewable energy consumption.

Several surrounding states have aggressive (RPS) that create a market for solar RECs (SCRECs), but neither TN nor KY have such policies themselves. SRECs can always be sold on the open wholesale market, but their going rate is usually less than $10 \notin / \mathrm{kWh}$, and typically less than or equal to $5 \phi / \mathrm{kWh}$. However, there are several states around Fort Campbell that have solar carve outs including: Missouri (0.3\% solar by 2021), Illinois ( $1.5 \%$ PV by 2025$)$, OH (0.5\% solar by $2025)$, and NC (0.2\% solar by 2018), and selling RECs to utilities in these states might be an option (Desire 2010). Specifically:

The MO RPS does allow for credit trading, but only a limited number of RECs are allowed to be submitted towards meeting the RPS goal, and out-of-state RECs must compete with instate RECs, which receive a 1.25 multiplier. RECs must be registered and tracked with the North American Renewable s Registry (Desire 2010).

The IL RPS does allow for credit trading, but only $50 \%$ of eligible utilities RE obligations may be met through RECs. RECs must utilize the PJM Environmental System Generation Attribute Tracking System (PJM-GATS) or the Midwest Renewable Energy Tracking System (M-RETS) to independently verify the quantity and source of renewable energy resources procured (Desire 2010).

The OH RPS also allows for credit trading, but only 50\% of the RE can be procured from out of state sources. The utility utilizing RECs for compliance must be a registered member with PJM's generation attribute tracking system (GATS) and/or Midwest Independent Transmission System Operator (MISO) generation attribute tracking system, and/or other credible tracking system PUCO subsequently approves. Utilities must be $4.5 \phi / \mathrm{kWh}$ for being out of compliance (Desire 2010).

The NC RPS allows for credit trading, but only $25 \%$ of RECs can be source from out of state and RECs must be in the North Carolina Renewable Energy Tracking System (NC-RETS) (Desire 2010).

Lastly, utilities in other states with solar carve outs may also be able to purchase SRECs provided the RPS allows such transfers.

In short, the presence of PV friendly RPS in surrounding states that allow RECs to be submitted in-kind for produced renewable energy may allow for a cost-effective PV project at Fort Campbell, but REC prices would need to be high, which is not likely. 


\section{Solar: Next Steps}

Solar energy projects are not cost-effective at this time because of Fort Campbell's moderate solar energy resource and current PV capital costs. Although the economics are unfavorable, there is interest at Fort Campbell in solar projects, so Fort Campbell should continue to monitor the market conditions affecting solar energy, the incentives available, and the installation's energy needs so a project can be reevaluated in the future if conditions change favorably.

Advances in PV technology are expected to produce less expensive solar cells, although rising demand for PV may negate some of the potential price drop. Rising energy rates may do the most to tip the scales in favor of solar electric. Probably the most important factor in making solar electric work at a Federal installation is identifying key partners - a private developer, a utility, or both - that can provide funding, capture tax incentives, purchase or market RECs, enter into PPAs, and provide other project support.

\section{Solar Sources of Information}

DSIRE- Database of State Incentives for Renewables \& Efficiency. 2010. Accessed April 2010 at http://www.dsireusa.org/.

DOE - U.S. Department of Energy. 1997. Renewable Energy Technology Characterizations December 1997 - Solar Parabolic Trough. TR-109496, Office of Utility Technologies, Energy Efficiency and Renewable Energy, U.S. Department of Energy and Electric Power Research Institute, Inc., Washington, DC. Accessed May 2010 at http://www1.eere.energy.gov/ba/pba/tech_characterizations.html.

DOE - U.S. Department of Energy. 1997. Renewable Energy Technology Characterizations December 1997 - Solar Power Tower. TR-109496, Office of Utility Technologies, Energy Efficiency and Renewable Energy, U.S. Department of Energy and Electric Power Research Institute, Inc., Washington, DC. Accessed May 2010 at http://www1.eere.energy.gov/ba/pba/tech_characterizations.html.

DOE - U.S. Department of Energy. 1997. Renewable Energy Technology Characterizations December 1997 - Solar Dish Engine. TR-109496, Office of Utility Technologies, Energy Efficiency and Renewable Energy, U.S. Department of Energy and Electric Power Research Institute, Inc., Washington, DC. Accessed May 2010 at http://www1.eere.energy.gov/ba/pba/tech_characterizations.html.

DOE - U.S. Department of Energy. 2010. 2008 Solar Technologies Market Report. Solar Energy Technologies Program, U.S. Department of Energy. Washington, DC. Accessed June 2010 at http://www1.eere.energy.gov/solar/pdfs/46025.pdf.

Emerging Energy Research, LTD. 2007. Global Concentrating Solar Power Markets and Strategies, 2007-2020. Emerging Energy Research, LTD., Cambridge, MA.

Minister of Natural Resources Canada. 2008. RETscreen Clean Energy Project Analysis Software. RETScreen International Clean Energy Decision Support Centre, Minister of Natural Resources Canada, Ottawa, Ontario, Canada. Accessed May 2010 at http://www.retscreen.net (last updated March 3, 2010). 
NASA - National Aeronautics and Space Administration's Langley Research Center and Atmosphere Science Data Center. 2010. Surface meteorology and Solar Energy. Accessed May 2010 at http://eosweb.larc.nasa.gov/sse (last updated May 4, 2010).

NREL - National Renewable Energy Laboratory. 2008. U.S. Solar Resource Map. Accessed November 2009 at http://www.nrel.gov/gis/solar.html.

Sargent \& Lundy Consulting Group. 2003. Assessment of Parabolic Trough and Power Tower Solar Technology Cost and Performance Forecasts. NREL/SR-550-34440, prepared by Sargent \& Lundy LLC Consulting Group for the National Renewable Energy Laboratory, Chicago, IL.

Stoddard L, J Abiecunas, and R O'Connell. 2006. Economic, Energy, and Environmental Benefits of Concentrating Solar Power in California. NREL/SR-550-39291, prepared by Black \& Veatch for the National Renewable Energy Laboratory, Overland Park, KS.

Wiser R, G Barbose and C Peterman. 2009. Tracking the Sun: The Installed Cost of Photovoltaics in the U.S. from 1998-2007. LBNL-1516E, Environmental Energy Technologies Division, Lawrence Berkeley National Laboratory, Berkeley, CA. Accessed May 2010 at http://eetd.lbl.gov/ea/ems/re-pubs.html. 


\section{APPENDIX F}

Analysis of Wind Opportunities 
Renewable Energy Opportunities at Fort Campbell, Tennessee/Kentucky Pacific Northwest National Laboratory, March 2011 


\section{Appendix F: Analysis of Wind Opportunities}

\section{Wind Technology}

There is a vast wind resource in the United States. The American Wind Energy Association states that domestic wind resources, which are economically feasible in at least 46 states, could theoretically supply all of the nation's electricity needs (AWEA 2007). At the current time, however, less than $2 \%$ of the nation's power is generated from wind, though electricity generation from wind power projects continues to increase. In 2008, wind power projects accounted for $42 \%$ of all the new generating capacity installed in the United States, up from $2 \%$ of installed capacity in 2004 (AWEA 2009).

Wind projects, often referred to as wind farms, can be categorized by scale. Large, utility-scale projects tend to be $50 \mathrm{MW}$ and above, with the world's largest single wind farm being in Texas at over $700 \mathrm{MW}$. Smaller-sized projects (under $50 \mathrm{MW}$ ) are often referred to as community wind projects or distributed generation (DG) projects. Community wind projects involve local ownership structures, often with corporate partners taking advantage of the federal production tax credit. DG projects are designed to offset the owner's retail electricity purchases by producing power that is used on-site, with any surplus sold to a commercial utility.

Wind turbines come in many different sizes and configurations. Wind turbines in the U.S. generally employ the Danish configuration - a horizontal-axis, three-bladed rotor, an upwind orientation, and an active yaw system to keep the rotor oriented into the wind.

Utility-scale turbines for bulk power production tend to be $660 \mathrm{~kW}$ to $3 \mathrm{MW}$ in size. Hub heights can range from 50 meters (164 feet) to 100 meters (328 feet). Industrial turbines for consumer and remote grid production are found in the range of $50 \mathrm{~kW}$ to $250 \mathrm{~kW}$. Hub heights range between 25 meters ( 80 feet) and 40 meters (131 feet). Residential-scale wind turbines are used for remote power, battery charging, or net-metering generation. These turbines tend to be 400 watts to $50 \mathrm{~kW}$. For turbines greater than $1 \mathrm{~kW}$, the hub heights range from 12 meters (40 feet) to 36 meters (120 feet).

The land required for a single utility-scale wind turbine is typically 3 acres, including access roads, turbine base, and other equipment. A wind turbine located on a ridgeline in hilly terrain will require less area than one on flat land, as little as 2 acres per MW. The proper spacing of turbines is essential to reduce wake interference and optimize the wind resource. In open flat terrain, a utility-scale wind plant will require a buffer space of about 60 acres per MW of installed capacity.

Although more difficult to finance and lacking in economies of scale, smaller-sized wind generation projects offer some potential benefits over large-scale wind farms:

$\checkmark$ A smaller project is often easier to permit and may be less likely to interfere with other land uses (including military missions).

$\checkmark$ On-site power generation that is integrated into the site electrical system provides energy security.

$\checkmark$ It may be possible to avoid building a costly substation if a suitably-sized power interconnection is located near a promising site for wind turbines. 


\section{Wind Analysis Approach}

The current wind analysis approach draws from several sources.

\section{DoD Assessment Approach}

The DoD Renewables Study (Conover et al. 2004) relied upon wind resource maps developed by the National Renewable Energy Laboratory (NREL), maps developed by independent companies, and PNNL's Wind Energy Resource Atlas of the United States to identify the installations with best potential for commercial-scale wind farms. The DoD analysis used the highest resolution map available for each state to quantify the wind resource on the military land in that state. Over 70 Army and Air Force installations were reviewed with respect to both wind resource and compatibility with the installation's mission. About 20 installations with potential for projects were selected for follow-on detailed assessments. Fort Campbell was not included in that study.

\section{PNNL Wind Analysis Approach}

For this updated analysis, PNNL used the following approach to analyze the economic potential for wind energy at Fort Campbell. More detail on the financing scenarios, generic analytic approach, and economic and other parameters used in this analysis are documented in Appendix A of this report.

(1) Wind resource maps were analyzed.

(2) Existing on-site interconnection and transmission capacity and availability were evaluated.

(3) Local wind developer activity in the area was surveyed to assess potential interest in developing projects.

(4) A turbine model was selected to establish cost and performance parameters.

(5) Total project cost was estimated, including project development, generation equipment, balance of plant construction, interconnection and transmission, operation and maintenance (O\&M), taxes, and tax credits and other policy incentives.

(6) Economic feasibility was determined utilizing different financing scenarios: independent power producer (IPP) and Energy Conservation Investment Program (ECIP).

(7) Project feasibility was determined and next steps recommended.

\section{Wind Resource Characterization}

According to industry standards developed as part of the Wind Energy Resource Atlas of the United States, there are seven main classes of wind power, as shown in Table F-1. 
Table F-1: Classes of Wind Power Density at 50 Meters

\begin{tabular}{||c|c|c||}
\hline Wind Power Class & Wind Power Density, W/m & Speed, m/s (mph) \\
\hline $\mathbf{1}$ & $<200$ & $<5.6(12.5)$ \\
\hline $\mathbf{2}$ & $200-300$ & $5.6(12.5)-6.4(14.3)$ \\
\hline $\mathbf{3}$ & $300-400$ & $6.4(14.3)-7.0(15.7)$ \\
\hline $\mathbf{4}$ & $400-500$ & $7.0(15.7)-7.5(16.8)$ \\
\hline $\mathbf{5}$ & $500-600$ & $7.5(16.8)-8.0(17.9)$ \\
\hline $\mathbf{6}$ & $600-800$ & $8.0(17.9)-8.8(19.7)$ \\
\hline $\mathbf{7}$ & $>800$ & $>8.8(19.7)$ \\
\hline
\end{tabular}

A strong Class 3 resource, preferably Class 4, is generally required to achieve an economic project on a large, commercial scale. According to the Kentucky and Tennessee wind resource maps (NREL 2008a, NREL 2008b), both states have a Class 1 wind resource, which is typical for the southeast region of the United States. A Class 1 wind resource is not sufficient to support a large-scale wind energy project.

To determine an average annual wind speed estimate for Fort Campbell, the windNAVIGATOR wind mapping tool from AWS Truewind was used. At 80 meters above ground, a typical hub height for commercial-scale turbines, the average annual wind speed found on-site is $5.0 \mathrm{~m} / \mathrm{s}$ (AWS Truewind 2009), as shown in Figure F-1.

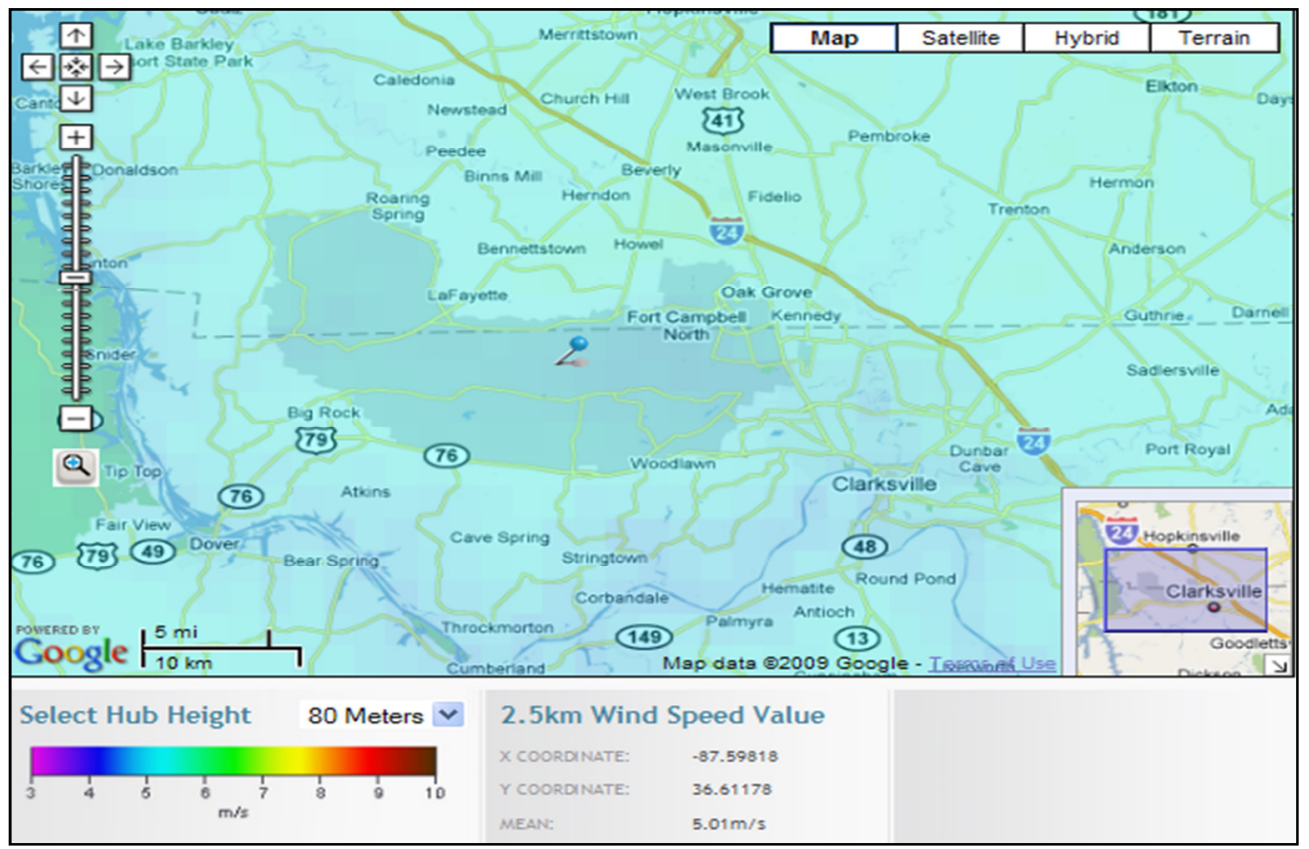

Figure F-1: Average Wind Speed on Fort Campbell (AWS Truewind 2009)

National Aeronautics and Space Administration's (NASA) Langley Research Center Atmospheric Science Data Center was used as a reference comparison for Fort Campbell's average wind speed. NASA Surface Meteorology and Solar Energy (SSE) database provides data on a $1^{\circ}$ by $1^{\circ}$ grid system, based on wind speed data over a 10-year period from July 1983 to 
June 1993. According to this source, the annual average wind speed in the Fort Campbell area is $4.58 \mathrm{~m} / \mathrm{s}$ at 50 meters (NASA 2009).

To exactly determine an area's wind resource, the installation of a meteorological tower ("met tower") is required. Using a 60-meter met tower to collect wind data for one year is the current industry standard for commercial-scale projects.

Table F-2 summarizes Fort Campbell's wind resource according to the available data sources.

Table F-2: Summary of Wind Resource Data

\begin{tabular}{||c|l|l||}
\hline \multicolumn{1}{|c|}{ Location } & \multicolumn{1}{|c|}{ Source } & \multicolumn{1}{c|}{ Wind Speed } \\
\hline \multirow{4}{*}{ Fort Campbell } & Wind Resource Maps & Class $1(0.0-5.7 \mathrm{~m} / \mathrm{s}$ at $50 \mathrm{~m})$ \\
\cline { 2 - 3 } & $\begin{array}{l}\text { windNavigator tool from } \\
\text { AWS Truewind }\end{array}$ & $5.0 \mathrm{~m} / \mathrm{s}$ at $80 \mathrm{~m}$ \\
\cline { 2 - 3 } & NASA SSE data & $4.58 \mathrm{~m} / \mathrm{s}$ at $50 \mathrm{~m}$ \\
\hline
\end{tabular}

\section{Siting Considerations}

After wind resource availability, the primary siting consideration for grid-connected wind projects is transmission availability and the capacity of those lines at considerable cost.

This analysis does not include any transmission costs and assumes that existing transmission lines are available to transmit power without substantial additional investment. It is also assumed that an on-site wind project would not trigger new standby or other fees from the local utility. But because wind is intermittent, the utility may have interconnection requirements to ensure grid stability and to ensure there is reliable power for the installation.

Another consideration is potential interference with airport operations. Fort Campbell has an airfield on the Kentucky side of the installation in the northeast corner. The Federal Aviation Administration (FAA) requires Notice of Proposed Construction for a project that meets certain criteria so that it can determine if there would be adverse impacts to air navigation safety. One of the triggering criteria is whether the project would be located within 20,000 feet (3.8 miles) or less of an existing public or military airport. When selecting an area for a wind project, it would be best to avoid this potential interference issue by locating the project outside of the 20,000-foot range. Any potential wind project would need to carefully consider this concern. The western portion of the installation on the Kentucky side should be sufficiently distant from the airfield and this location was used in the analysis. An additional FAA criterion that would necessitate a Notice of Proposed Construction is any construction or alteration of more than 200 feet (61 meters) in height above ground level. This criterion applies regardless of the distance from the proposed project to an airport.

In response to the filing of a Notice of Proposed Construction, the FAA can halt a project, require modifications be made to the project, or issue a "No Hazard to Air Navigation" determination and the wind project can proceed. 


\section{Wind: Economic and Other Analysis Parameters}

This assessment considered the current federal wind incentives: a $2.1 \not / \mathrm{kWh}$ renewable energy production tax credit (PTC) and 5-year accelerated depreciation. State-specific incentives applicable to wind energy projects for Kentucky and Tennessee were also examined. Kentucky provides a sales tax exemption where Tennessee does not, so the project was assumed to be in the western part of the installation on the Kentucky side. These incentives are discussed in Appendix A.

During the DoD Renewables Study completed in 2004, the installed cost of capital was approximately $\$ 1,400 / \mathrm{kW}$; at the current time, prices range from $\$ 1,700$ to $\$ 2,600 / \mathrm{kW}$ because of high demand and increased costs for components. The capital cost was assumed to be $\$ 2,169 / \mathrm{kW}$ (including incentives and taxes) for this economic assessment.

Because a wind energy project would provide intermittent power to the installation, the economics of a wind project are evaluated against the installation's direct energy charge of $4.14 \phi / \mathrm{kWh}$ to exclude demand and other fixed charges.

Further details on the analysis methodology and the economic and incentive parameters are documented in Appendix A, and the assumptions used are listed in Table F-3.

Table F-3: Performance, Cost, and Economic Characteristics

\begin{tabular}{|l|l|}
\hline Location & Fort Campbell, Kentucky \\
\hline Conditions & Standard: $1.225 \mathrm{~kg} / \mathrm{m}^{3}$ density, $0^{\circ} \mathrm{F}, 0 \mathrm{ft}$ elevation \\
\hline Assumed Average Wind Speed & $5.0 \mathrm{~m} / \mathrm{s}$ at $80 \mathrm{~m}$ \\
\hline Net Capacity Factor & $13.5 \%$ \\
\hline Turbine Type & $1.5 \mathrm{MW}, 77 \mathrm{~m}$ rotor, $80 \mathrm{~m}$ hub \\
\hline Project Size & 1 turbine, $1.5 \mathrm{MW}$ total \\
\hline Estimated Net Annual Energy Production & $1,768,919 \mathrm{kWh} / \mathrm{yr}$ \\
\hline Energy Charge & $4.14 \phi / \mathrm{kWh}$ \\
\hline Total Capital Cost & $\$ 2,169 / \mathrm{kW}$ \\
\hline Fixed O\&M Cost & $\$ 60 / \mathrm{kW}$ \\
\hline 5-year accelerated depreciation & Included \\
\hline Federal 2.1 c/kWh PTC & Included \\
\hline REC Sales & Not Included \\
\hline Transmission Costs & Not Included \\
\hline
\end{tabular}

\section{Findings: Wind}

The various energy cost scenarios were evaluated for ECIP eligibility and IPP project potential. To qualify for ECIP funding, a project must achieve a savings-to-investment ratio (SIR) of 1.0, and its payback is also examined. For the IPP evaluation, the commercial cost of energy was calculated to obtain an internal rate of return (IRR) of $10 \%$. This was used as the minimum IRR required to attract the interest of a wind power project developer. Table F-4 lists the results of these analyses. 
Table F-4: Economic Assessment of Wind Power

\begin{tabular}{||c|c|c|c||}
\hline Financing Scenario & \multicolumn{2}{|c|}{ ECIP } & IPP \\
\hline Economic Factor & SIR & Simple Payback, years & Cost of Electricity at $10 \%$ IRR, $₫ / \mathrm{kWh}$ \\
\hline Results & negative & negative & 29.66 \\
\hline
\end{tabular}

\section{Wind: Next Steps}

As a result of the poor wind resource and resulting unfavorable economics, Fort Campbell should not pursue a wind energy project.

Fort Campbell's energy rates would have to drastically increase to make a wind project economically attractive given the area's poor wind resource. Fort Campbell currently enjoys low-cost power. The economic analysis of this report used the energy charge of $4.14 \phi / \mathrm{kWh}$. In order to reach a $10 \%$ IRR with the $5.0 \mathrm{~m} / \mathrm{s}$ wind speed, the energy rate would have to increase to $29.66 \notin / \mathrm{kWh}$. This is a substantial rate increase and unlikely to happen.

The dictate of this assessment is to evaluate projects $1 \mathrm{MW}$ and larger. To facilitate this, the wind energy assessments are based on using the industry's current standard size wind turbine of $1.5 \mathrm{MW}$.

While Fort Campbell does not have the typical wind resource needed to support a wind project, Fort Knox has a similar wind resource to Fort Campbell's, but has implemented a small-scale wind project. Fort Knox's $1.8 \mathrm{~kW}$ wind turbine produces approximately 1,000 kWh per year, which translates to a capacity factor of about $6 \%$. This extremely low capacity factor demonstrates the poor wind resource of the area.

Information was not available on the economics of this project, but it would be beneficial for Fort Campbell to learn more about Fort Knox's project if Fort Campbell is interested in a smallscale wind project. Learning what, if any, incentives or other methods were used to reduce costs would be valuable.

While a wind project at Fort Campbell is not recommended and would only contribute a small amount of electricity, it could provide other benefits. Installing a wind turbine can immediately bring attention from the local community to a site's commitment to renewable energy, if for no other reason than wind energy has become synonymous with "going green." Other considerations are that the cost of wind power is not dependent upon the cost of fossil fuels, and a wind project may provide a small level of energy security.

\section{Wind Sources of Information}

AWEA - American Wind Energy Association. 2007. Wind Power Today. Accessed May 2010 at http://www.awea.org/pubs/factsheets/WindPowerToday_2007.pdf.

AWEA - American Wind Energy Association. 2009. Wind Power Outlook. Accessed May 2010 at http://www.awea.org/pubs/documents/Outlook_2009.pdf.

AWS Truewind. 2009. windNAVIGATOR. Accessed November 2009 at

http://navigator.awstruewind.com/. 
Conover K, KJ Smith, TM Jurotich. 2004. U.S. Department of Defense Renewable Energy Assessment Report of Wind Energy Potential On and Near Military Installations. Global Energy Concepts, Kirkland, Washington.

FAA - Federal Aviation Administration. 2007. Advisory Circular: Obstruction Marking and Lighting. AC 70/7460-1K, Federal Aviation Administration, Washington, DC. Accessed May 2010 at

http://www.airweb.faa.gov/Regulatory_and_Guidance_Library/rgAdvisoryCircular.nsf/0/b993dc dfc37fcdc486257251005c4e21/\$FILE/AC70_7460_1K.pdf.

NASA - National Aeronautics and Space Administration's Langley Research Center and Atmosphere Science Data Center. 2009. Surface meteorology and Solar Energy. Accessed November 2009 at http://eosweb.larc.nasa.gov/sse/ (last updated August 28, 2009).

NREL - National Renewable Energy Laboratory. 2008a. Tennessee - Annual Wind Power at 50-m Height. Prepared by the NREL for the U.S. Department of Energy, Washington, DC. Accessed November 2009 at http://www.windpoweringamerica.gov/images/windmaps/tn_50m_800.jpg (last updated September 26, 2008).

NREL - National Renewable Energy Laboratory. 2008b. Kentucky - Annual Wind Power at 50$m$ Height. Prepared by the NREL for the U.S. Department of Energy, Washington, DC. Accessed November 2009 at http://www.windpoweringamerica.gov/images/windmaps/ky_50m_800.jpg (last updated September 26, 2008).

PNL - Pacific Northwest Laboratory. 1986. Wind Energy Resource Atlas of the United States. Solar Technical Information Program \& Solar Energy Research Institute, Golden, Colorado. Available at http://rredc.nrel.gov/wind/pubs/atlas/atlas_index.html. 

Pacific Northwest National Laboratory, March 2011 


\section{APPENDIX G}

\section{Analysis of Shale Gas Opportunities}


Renewable Energy Opportunities at Fort Campbell, Tennessee/Kentucky Pacific Northwest National Laboratory, March 2011 


\section{Appendix G: Analysis of Shale Gas Opportunities}

\section{Shale Gas as an Energy Resource}

Shale is a fine-grained sedimentary rock that is formed by compaction of an organic-rich mudlike substance that often accumulates at the base of stagnant water bodies by the settling of very fine particles that would otherwise remain suspended in moving water. During the compaction process, tiny microorganisms known as methanogens begin the process of chemically breaking down organic matter, which produces biogenic methane as a byproduct in areas near the surface of the earth that are void of oxygen. Methane that becomes trapped underground can then be recovered as natural gas. Another form of biogenic methane is landfill gas, which forms from the decomposition of waste materials broken down by methanogens through the same process.

Several wells recently installed at Fort Knox, Kentucky are currently producing biogenic methane gas from shale formations at 500 to $600 \mathrm{ft}$ below ground (Meredith 2009). The methane gas produced at Fort Knox has provided substantial energy savings by replacing nearly all utilityprovided natural gas that was used to produce the domestic hot water requirements at Fort Knox (Meredith 2009). Successful shale gas production at Fort Knox has generated interest in exploring shale gas opportunities at Fort Campbell, which is located approximately 130 miles to the southwest in an area that has a similar geologic setting.

\section{Shale Gas Opportunities at Fort Campbell}

Fort Campbell is located near the southern edge of the Illinois Basin (Figure G-1), one of America's oldest oil and gas provinces. The Illinois Basin is a large depositional and structural basin encompassing approximately $60,000 \mathrm{mi}^{2}\left(155,000 \mathrm{~km}^{2}\right)$ and spanning across four states: Illinois, Indiana, Kentucky, and Tennessee.

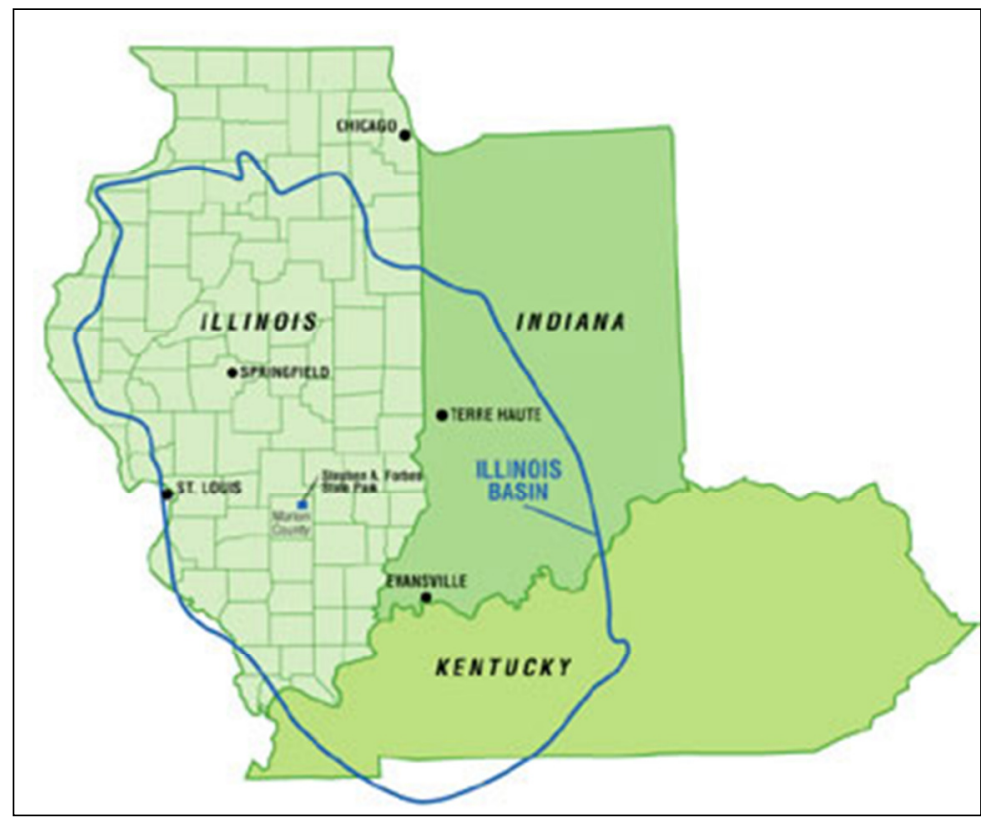

Figure G-1: Map of Illinois Basin (Smith Oil Group INC., 2006) 
Historical production of oil and natural gas in the Illinois Basin has primarily been limited to conventional targets, such as isolated zones of porous and/or fractured rock where it lies trapped by overlying rock formations with lower permeability, or by structural features such as faults and folds (i.e., flat plates of rock or sediment bent into a curved formation). However, recent drilling activity in the Illinois Basin has mainly been focused on shale gas produced from the New Albany Shale. The New Albany Shale is a Devonian age (416 to 359 million years old), hydrocarbon rich shale that underlies much of the Illinois Basin (Macke 1995). In general, the New Albany Shale is relatively shallow in terms of oil and gas drilling (600 to 5,000 ft) and has sufficient thickness and natural fractures to accommodate accumulation of natural gas pockets (IBC 1994).

According to the Energy Information Administration's map of active shale gas plays in the United Sates (EIA 2010), Fort Campbell is located to the south of the New Albany shale gas play (Figure G-2), which is the region within the Illinois basin that is generally recognized for having an economic quantity of gas.

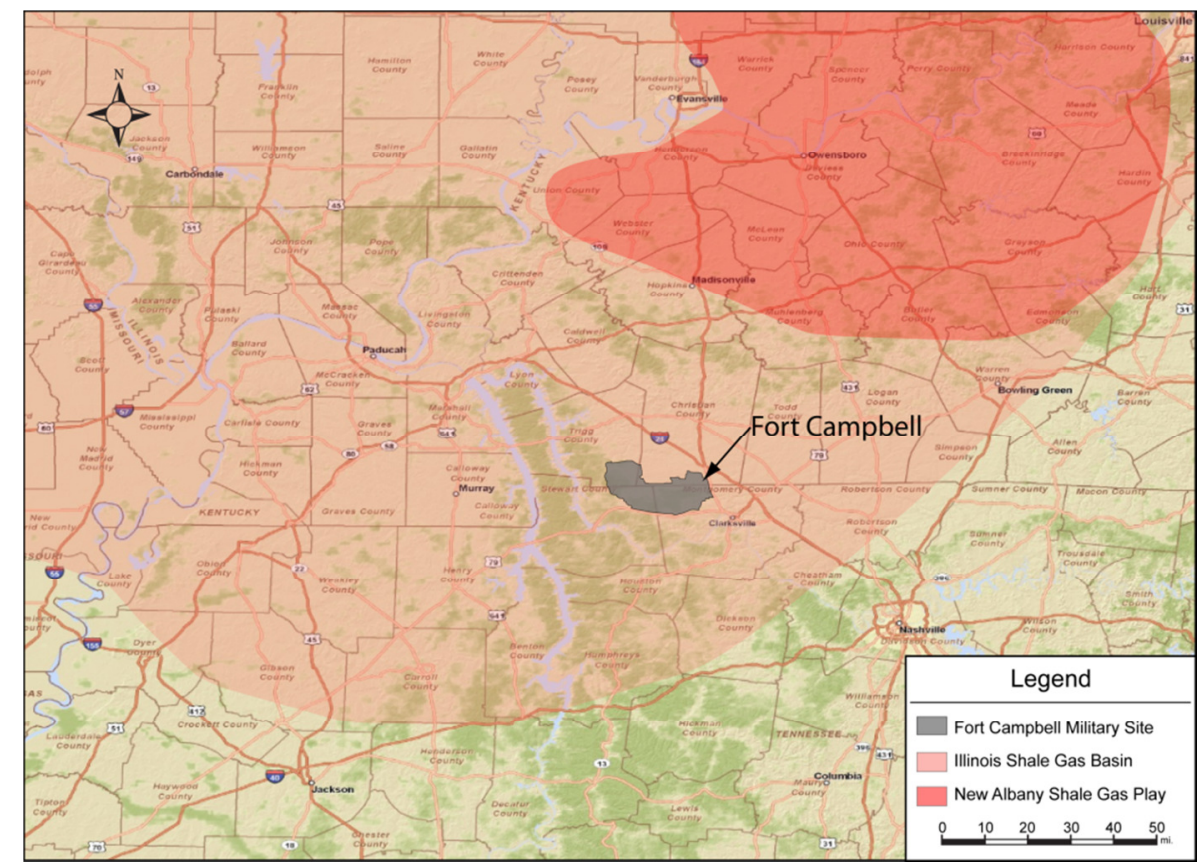

Figure G-2: Location of Fort Campbell in Relation to the New Albany Shale Gas Play (EIA 2010)

The area included in the play is defined by the area of occurrence of organic-rich shale (Macke 1995), which indicates the potential for generation and accumulation of natural gas. Areas located outside the play are generally considered organic-lean (Macke 1995), suggesting a lower probability for the production of gas. Although the thickness of the New Albany Shale beneath Fort Campbell is estimated at over $100 \mathrm{ft}$ thick (KNG 2005), the quality and abundance of methane that could potentially be produced from the New Albany shale was not determined for this report. Additional investigations should focus on using existing published resources that could help identify the geochemical, lithologic, structural and stratigraphic conditions of the New Albany Shale beneath Fort Campbell. 
References:

EIA - U.S. Energy Information Administration. 2010. Map of Active Shale Gas Plays, Lower 48 States. Accessed August 15, 2010 at

http://www.eia.doe.gov/pub/oil_gas/natural_gas/analysis_publications/maps/maps.htm (last updated March 10, 2010).

IBC - Illinois Basin Consortium. 1994. Gas Potential of the New Albany Shale (Devonian Mississippian) in the Illinois Basin, eds. NR Hasenmueller and JB Corner, prepared for the Gas Research Institute, GRI-92/0391. Accessed August 16, 2010 at http://www.sitterdrilling.com/docs/Gas_Research_Institute.pdf.

KNG - Kentucky Natural Gas Corporation. 2005. Devonian Shale in Kentucky. Accessed August 16, 2010 at http://www.kentuckynaturalgas.com/Devonian_Shale.html (copyright dated 2005).

Macke, DL. 1995. "Illinois Basin Province (064)." in National assessment of United States oil and gas resources-Results, methodology, and supporting data, eds. DL Gautier, GL Dolton, LI Takahashi, and KL Varnes, U.S. Geological Survey Digital Data Series DDS-30, Release 2, one CD-ROM. http://certmapper.cr.usgs.gov/data/noga95/prov64/text/prov64.pdf

Meredith, Gary. 2009. Unconventional Renewable Methane at Knox. Fort Knox, Kentucky. Smith Oil Group, INC. 2006. The Illinois Basin and New Albany Shale. Accessed on August 16, 2010 at http://www.smithoilgroup.com/index.php?page=projects\&sub=IllinoisBasin 
G-4

Renewable Energy Opportunities at Fort Campbell, Tennessee/Kentucky Pacific Northwest National Laboratory, March 2011 


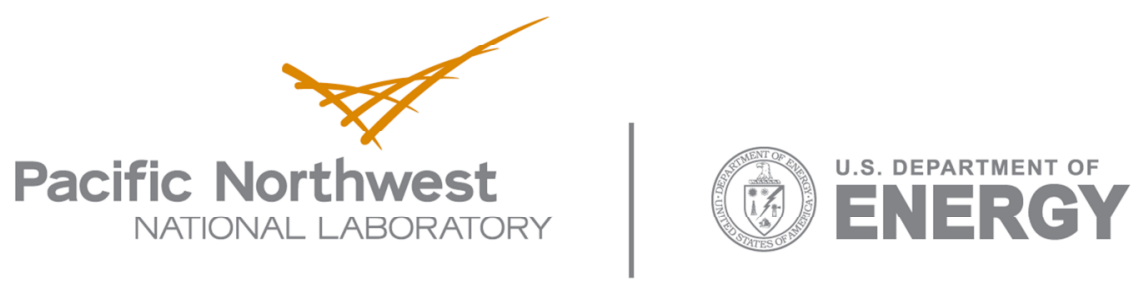

902 Battelle Boulevard

P.O. Box 999

Richland, WA 99352

1-888-375-PNNL (7665)

www.pnl.gov 